\title{
Interventions for preventing and treating incontinence-associated dermatitis in adults (Review)
}

Beeckman D, Van Damme N, Schoonhoven L, Van Lancker A, Kottner J, Beele H, Gray M, Woodward S, Fader M, Van den Bussche K, Van Hecke A, De Meyer D, Verhaeghe S

Beeckman D, Van Damme N, Schoonhoven L, Van Lancker A, Kottner J, Beele H, Gray M, Woodward S, Fader M, Van den Bussche K, Van Hecke A, De Meyer D, Verhaeghe S.

Interventions for preventing and treating incontinence-associated dermatitis in adults.

Cochrane Database of Systematic Reviews 2016, Issue 11. Art. No.: CD011627.

DOI: 10.1002/14651858.CD011627.pub2.

www.cochranelibrary.com 
TABLE OF CONTENTS

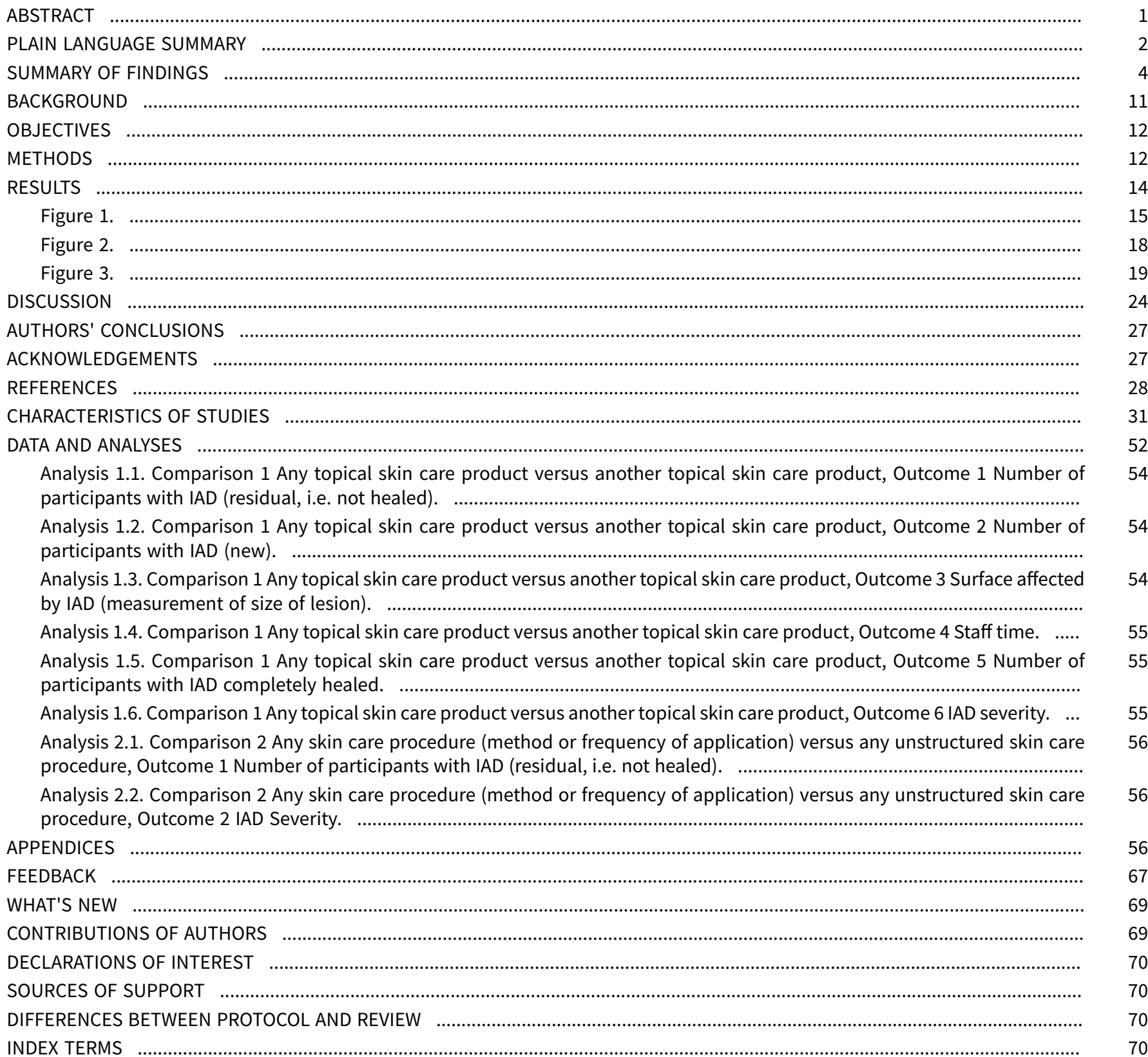


[Intervention Review]

\section{Interventions for preventing and treating incontinence-associated dermatitis in adults}

Dimitri Beeckman¹, Nele Van Damme1, Lisette Schoonhoven², Aurélie Van Lancker¹, Jan Kottner ${ }^{3}$, Hilde Beele ${ }^{4}$, Mikel Gray 5 , Sue Woodward 6 , Mandy Fader ${ }^{7}$, Karen Van den Bussche ${ }^{1}$, Ann Van Hecke ${ }^{1}$, Dorien De Meyer ${ }^{1}$, Sofie Verhaeghe ${ }^{1}$

1 University Centre for Nursing and Midwifery, Department of Public Health, Ghent University, Ghent, Belgium. 2Fundamental Care \& Safety Research Group, Faculty of Health Sciences, University of Southampton, Southampton, UK. ${ }^{3}$ Clinical Research Center for Hair and Skin Science, Department of Dermatology and Allergy, Charité-Universitätsmedizin Berlin, Berlin, Germany. ${ }^{4}$ Department of Dermatology, Wound Care Clinic, Ghent University, Ghent University Hospital, Ghent, Belgium. ${ }^{5}$ Department of Urology, University of Virginia, Charlottesville, Virginia, USA. ${ }^{6}$ King's College London, London, UK. ${ }^{7}$ Faculty of Health Sciences, University of Southampton, Southampton, UK

Contact: Dimitri Beeckman, University Centre for Nursing and Midwifery, Department of Public Health, Ghent University, De Pintelaan 185, Ghent, 9000, Belgium. Dimitri.Beeckman@UGent.be.

Editorial group: Cochrane Incontinence Group.

Publication status and date: Edited (no change to conclusions), comment added to review, published in Issue 8, 2017.

Citation: Beeckman D, Van Damme N, Schoonhoven L, Van Lancker A, Kottner J, Beele H, Gray M, Woodward S, Fader M, Van den Bussche K, Van Hecke A, De Meyer D, Verhaeghe S. Interventions for preventing and treating incontinence-associated dermatitis in adults. Cochrane Database of Systematic Reviews 2016, Issue 11. Art. No.: CD011627. DOI: 10.1002/14651858.CD011627.pub2.

Copyright $\odot 2017$ The Cochrane Collaboration. Published by John Wiley \& Sons, Ltd.

\section{A B S T R A C T}

\section{Background}

Incontinence-associated dermatitis (IAD) is one of the most common skin problems in adults who are incontinent for urine, stool, or both. In practice, products and procedures are the same for both prevention and treatment of IAD.

\section{Objectives}

The objective of this review was to assess the effectiveness of various products and procedures to prevent and treat incontinence-associated dermatitis in adults.

\section{Search methods}

We searched the Cochrane Incontinence Group Specialised Trials Register, which contains trials identified from the Cochrane Central Register of Controlled Trials (CENTRAL), MEDLINE, MEDLINE In-Process, MEDLINE Epub Ahead of Print, CINAHL, ClinicalTrials.gov, WHO ICTRP and handsearching of journals and conference proceedings (searched 28 September 2016). Additionally we searched other electronic databases: CENTRAL(2015, Issue 4), MEDLINE (January 1946 to May Week 3 2015), MEDLINE In-Process (inception to 26 May 2015), CINAHL(December 1981 to 28 May 2015), Web of Science (WoS; inception to 28 May 2015) and handsearched conference proceedings (to June 2015) and the reference lists of relevant articles, and contacted authors and experts in the field.

\section{Selection criteria}

We selected randomised controlled trials (RCTs) and quasi-RCTs, performed in any healthcare setting, with included participants over 18 years of age, with or without IAD. We included trials comparing the (cost) effectiveness of topical skin care products such as skin cleansers, moisturisers, and skin protectants of different compositions and skin care procedures aiming to prevent and treat IAD.

\section{Data collection and analysis}

Two review authors independently screened titles, abstracts and full-texts, extracted data, and assessed the risk of bias of the included trials. 


\section{Main results}

We included 13 trials with 1316 participants in a qualitative synthesis. Participants were incontinent for urine, stool, or both, and were residents in a nursing home or were hospitalised.

Eleven trials had a small sample size and short follow-up periods. The overall risk of bias in the included studies was high. The data were not suitable for meta-analysis due to heterogeneity in participant population, skin care products, skin care procedures, outcomes, and measurement tools.

Nine trials compared different topical skin care products, including a combination of products. Two trials tested a structured skin care procedure. One trial compared topical skin care products alongside frequencies of application. One trial compared frequencies of application of topical skin care products.

We found evidence in two trials, being of low and moderate quality, that soap and water performed poorly in the prevention and treatment of IAD (primary outcomes of this review). The first trial indicated that the use of a skin cleanser might be more effective than the use of soap and water (risk ratio (RR) $0.39,95 \%$ confidence interval $(\mathrm{Cl}) 0.17$ to 0.87 ; low quality evidence). The second trial indicated that a structured skin care procedure, being a washcloth with cleansing, moisturising, and protecting properties, might be more effective than soap and water (RR $0.31,95 \% \mathrm{Cl} 0.12$ to 0.79 ; moderate quality evidence). Findings from the other trials, all being of low to very low quality, suggest that applying a leave-on product (moisturiser, skin protectant, or a combination) might be more effective than not applying a leave-on product. No trial reported on the third primary outcome 'number of participants not satisfied with treatment' or on adverse effects.

\section{Authors' conclusions}

Little evidence, of very low to moderate quality, exists on the effects of interventions for preventing and treating IAD in adults. Soap and water performed poorly in the prevention and treatment of IAD. Application of leave-on products (moisturisers, skin protectants, or a combination) and avoiding soap seems to be more effective than withholding these products. The performance of leave-on products depends on the combination of ingredients, the overall formulation and the usage (e.g. amount applied). High quality confirmatory trials using standardised, and comparable prevention and treatment regimens in different settings/regions are required. Furthermore, to increase the comparability of trial results, we recommend the development of a core outcome set, including validated measurement tools. The evidence in this review is current up to 28 September 2016.

\section{PLAIN LANGUAGE SUMMARY}

\section{Interventions for preventing and treating incontinence-associated dermatitis in adults}

\section{Background}

Incontinence-associated dermatitis (IAD) is an inflammation of the skin due to contact with urine or stool. IAD occurs in people with involuntary loss of urine or stool (incontinence). The main symptom of IAD is skin redness. In addition, bullae, skin lesions, and skin infection may occur. IAD affects one to five in ten incontinent adults and is a risk factor for pressure-related skin problems. To prevent and treat IAD, skin cleansing and skin care products are recommended. Many skin care products and procedures are available. The skin care products can be divided into cleansers, moisturisers, and protectants which may be combined (for example, a cleanser/moisturiser). In practice, products and procedures are the same for both prevention and treatment.

\section{Review question}

This review clarified the effect of various skin care products and procedures to prevent and treat IAD.

\section{Study characteristics}

We included randomised controlled trials which compared skin care products, procedures, methods for using skin care products and frequencies of using a skin care product. The participants had to be over 18 years of age.

\section{Key results}

We found thirteen, mostly small, trials, involving 1316 participants. All participants were incontinent for urine, stool, or both and lived in nursing homes or were hospitalised. The trials tested skin care products, procedures, and frequencies of using a skin care product.

Two trials showed that soap and water performed poorly in the prevention and treatment of IAD. A skin cleanser or a washcloth with cleansing, moisturising and protecting properties may be more effective than soap and water. The findings from the other trials suggest that using a skin care product is more effective than withholding a skin care product. We found no evidence that one skin care product performed better than another. The trials did not report on adverse effects.

\section{Quality of evidence}


The quality of the evidence was low. Eleven trials had small numbers of participants and were of short duration. The overall risk of bias was high.

\section{Authors conclusions}

The trials included in this review tested skin care products, procedures and frequencies of using a skin care product. Very limited evidence exists on the effects of interventions for preventing and treating IAD in adults. Larger, long-term and well performed trials are required. Furthermore, we recommend the development of a list of outcomes which are important for patients and will guide researchers in their study. This list should include well developed tools to measure the items in order to obtain accurate results.

\section{How up-to-date is this review?}

The review authors searched for studies that had been published up to 28 September 2016. 


\section{SUMMARY OF FINDINGS}

\section{Summary of findings for the main comparison. Any topical skin care product versus another topical skin care product}

\section{Any topical skin care product versus another topical skin care product}

Patient or population: adults with incontinence

Setting: hospitals and nursing homes

Intervention: any topical skin care product

Comparison: another topical skin care product

\begin{tabular}{|c|c|c|c|c|c|c|}
\hline \multirow[t]{2}{*}{ Outcomes } & \multicolumn{2}{|c|}{$\begin{array}{l}\text { Anticipated absolute effects }{ }^{*} \\
(95 \% \mathrm{CI})\end{array}$} & \multirow[t]{2}{*}{$\begin{array}{l}\text { Relative effect } \\
(95 \% \mathrm{CI})\end{array}$} & \multirow{2}{*}{$\begin{array}{l}\text { № of partici- } \\
\text { pants } \\
\text { (studies) }\end{array}$} & \multirow{2}{*}{$\begin{array}{l}\text { Quality of the } \\
\text { evidence } \\
\text { (GRADE) }\end{array}$} & \multirow[t]{2}{*}{ Comments } \\
\hline & $\begin{array}{l}\text { Risk with skin } \\
\text { care product B }\end{array}$ & $\begin{array}{l}\text { Risk with skin } \\
\text { care product A }\end{array}$ & & & & \\
\hline Number of participants with IAD & \multicolumn{2}{|l|}{ Study population } & \multirow{2}{*}{$\begin{array}{l}\text { RR } 0.36 \\
(0.08 \text { to } 1.68)\end{array}$} & \multirow{2}{*}{$\begin{array}{l}31 \\
(1 \mathrm{RCT})\end{array}$} & \multirow{2}{*}{$\begin{array}{l}\oplus \ominus \ominus \ominus \\
\text { VERY LOW }\end{array}$} & \multirow[t]{2}{*}{ Based on one small study. } \\
\hline $\begin{array}{l}\text { (1) No-rinse skin cleanser and skin } \\
\text { cream (A) versus soap and water and lo- } \\
\text { tion (B) }\end{array}$ & 308 per 1.000 & $\begin{array}{l}111 \text { per } 1.000 \\
\text { ( } 25 \text { to } 517)\end{array}$ & & & & \\
\hline Number of participants with IAD & \multicolumn{2}{|l|}{ Study population } & \multirow{2}{*}{$\begin{array}{l}\text { RR } 1.16 \\
(1.00 \text { to } 1.34)\end{array}$} & \multirow{2}{*}{$\begin{array}{l}142 \\
(1 \mathrm{RCT})\end{array}$} & \multirow{2}{*}{$\begin{array}{l}\oplus \oplus \oplus \ominus \\
\text { MODERATE }\end{array}$} & \multirow{2}{*}{$\begin{array}{l}\text { Basd on one study and spon- } \\
\text { sored by industry. }\end{array}$} \\
\hline (2) Desitin (A) versus Calmoseptine (B) & 783 per 1.000 & $\begin{array}{l}908 \text { per } 1.000 \\
\text { (783 to } 1000)\end{array}$ & & & & \\
\hline Number of participants with IAD & \multicolumn{2}{|l|}{ Study population } & \multirow{2}{*}{$\begin{array}{l}\text { RR } 0.39 \\
(0.17 \text { to } 0.87)\end{array}$} & \multirow{2}{*}{$\begin{array}{l}65 \\
(1 \mathrm{RCT})\end{array}$} & \multirow{2}{*}{$\begin{array}{l}\oplus \oplus \ominus \ominus \\
\text { LOW }\end{array}$} & \multirow{2}{*}{$\begin{array}{l}\text { Based on one small study and } \\
\text { sponsored by industry. }\end{array}$} \\
\hline $\begin{array}{l}\text { (1) Skin cleanser (A) versus soap and wa- } \\
\text { ter (B) }\end{array}$ & 469 per 1.000 & $\begin{array}{l}183 \text { per } 1.000 \\
\text { (80 to } 408)\end{array}$ & & & & \\
\hline Number of participants with IAD & \multicolumn{2}{|l|}{ Study population } & \multirow{2}{*}{$\begin{array}{l}\text { RR } 1.03 \\
\text { (0.20 to } 5.19)\end{array}$} & \multirow{2}{*}{$\begin{array}{l}27 \\
(1 \mathrm{RCT})\end{array}$} & \multirow{2}{*}{$\begin{array}{l}\oplus \oplus \ominus \ominus \\
\text { LOW }\end{array}$} & \multirow[t]{2}{*}{ Based on one small study. } \\
\hline $\begin{array}{l}\text { (2) Sudocrem }(A) \text { versus zinc oxide } \\
\text { cream (B) }\end{array}$ & 182 per 1.000 & $\begin{array}{l}187 \text { per } 1.000 \\
(36 \text { to } 944)\end{array}$ & & & & \\
\hline \multirow{2}{*}{$\begin{array}{l}\text { Number of participants with IAD } \\
\text { (new) }\end{array}$} & \multicolumn{2}{|l|}{ Study population } & \multirow{2}{*}{$\begin{array}{l}\text { RR } 0.83 \\
(0.35 \text { to } 1.95)\end{array}$} & \multirow{2}{*}{$\begin{array}{l}64 \\
(1 \mathrm{RCT})\end{array}$} & \multirow{2}{*}{$\begin{array}{l}\oplus \oplus \ominus \ominus \\
\text { LOW }\end{array}$} & \multirow{2}{*}{$\begin{array}{l}\text { Based on one small study. Cor- } \\
\text { responding author was mem- } \\
\text { ber of the company who deliv- } \\
\text { ered the study products. }\end{array}$} \\
\hline & 273 per 1.000 & $\begin{array}{l}226 \text { per } 1.000 \\
\text { (95 to } 532 \text { ) }\end{array}$ & & & & \\
\hline
\end{tabular}




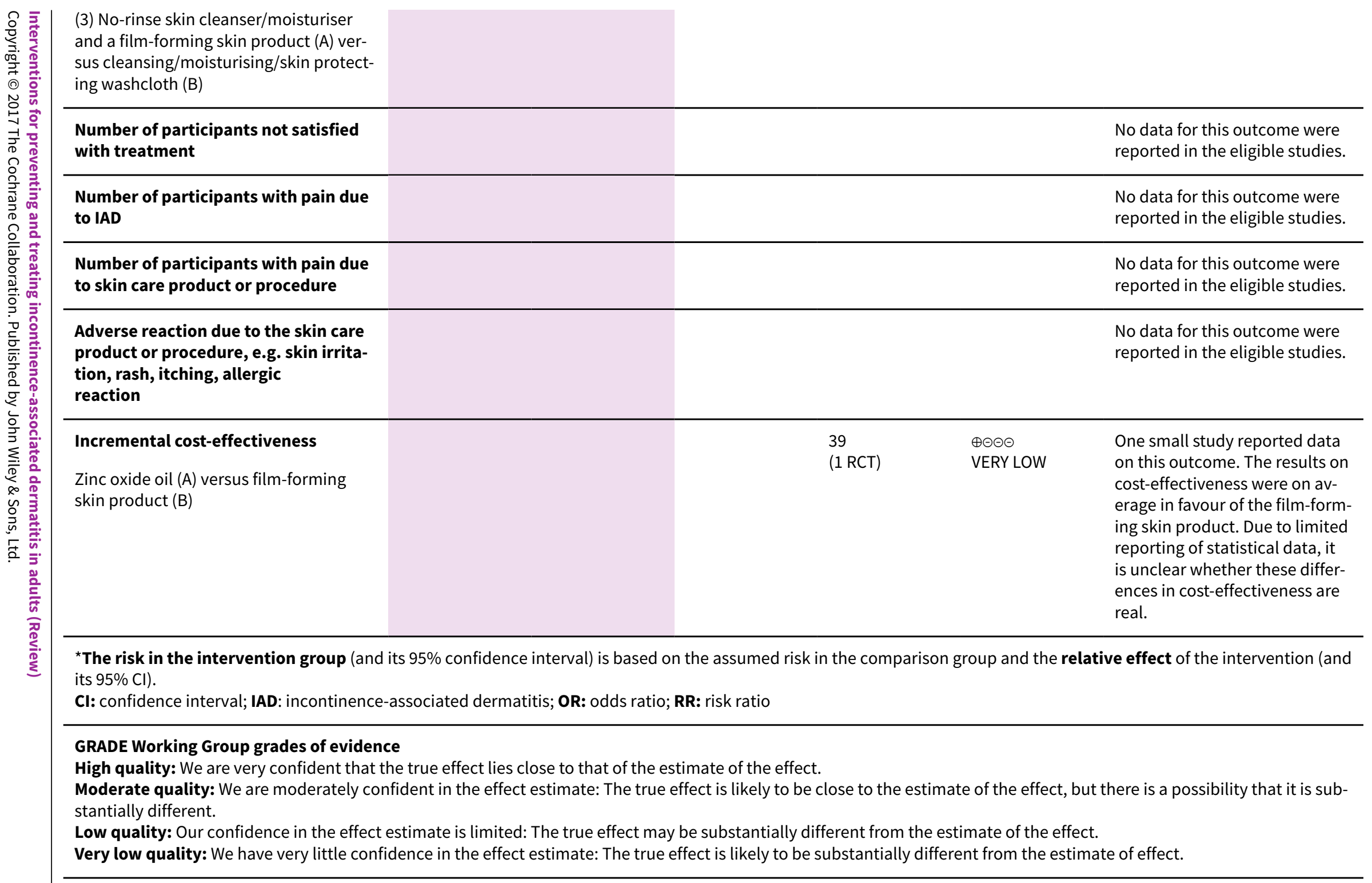

\section{Number of participants with pain due}

No data for this outcome were

No data for this outcome were

Number of participants with pain due

No data for this outcome were

Adverse reaction due to the skin care

product or procedure, e.g. skin irrita-

reported in the eligible studies.

\section{reaction}

Incremental cost-effectivenes

Zinc oxide oil (A) versus film-forming

39

$\oplus \odot \odot \odot$
VERY cost-effectiveness were on avences in cost-effectiveness are real.

${ }^{*}$ The risk in the intervention group (and its 95\% confidence interval) is based on the assumed risk in the comparison group and the relative effect of the intervention (and its $95 \% \mathrm{Cl})$.

\section{GRADE Working Group grades of evidence}

High quality: We are very confident that the true effect lies close to that of the estimate of the effect.

stantially different.

Very low quality: We have very little confidence in the effect estimate: The true effect is likely to be substantially different from the estimate of effect. 


\begin{tabular}{|c|c|c|c|c|c|c|}
\hline \multicolumn{7}{|c|}{ Any skin care procedure (method or frequency of application) versus any unstructured skin care procedure } \\
\hline \multicolumn{7}{|c|}{$\begin{array}{l}\text { Patient or population: adults with incontinence } \\
\text { Setting: nursing homes } \\
\text { Intervention: any skin care procedure (method or frequency of application) } \\
\text { Comparison: any unstructured skin care procedure }\end{array}$} \\
\hline \multirow[t]{2}{*}{ Outcomes } & \multicolumn{2}{|c|}{$\begin{array}{l}\text { Anticipated absolute effects } \\
(95 \% \mathrm{Cl})\end{array}$} & \multirow[t]{2}{*}{$\begin{array}{l}\text { Relative effect } \\
(95 \% \mathrm{CI})\end{array}$} & \multirow{2}{*}{$\begin{array}{l}\text { № of partici- } \\
\text { pants } \\
\text { (studies) }\end{array}$} & \multirow{2}{*}{$\begin{array}{l}\text { Quality of the } \\
\text { evidence } \\
\text { (GRADE) }\end{array}$} & \multirow[t]{2}{*}{ Comments } \\
\hline & $\begin{array}{l}\text { Risk with any } \\
\text { unstructured } \\
\text { skin care pro- } \\
\text { cedure (B) }\end{array}$ & $\begin{array}{l}\text { Risk with } \\
\text { any skin care } \\
\text { procedure } \\
\text { (method or fre- } \\
\text { quency of ap- } \\
\text { plication) (A) }\end{array}$ & & & & \\
\hline Number of participants with IAD & \multicolumn{2}{|c|}{ Study population } & \multirow{2}{*}{$\begin{array}{l}\text { RR } 0.31 \\
\text { (0.12 to } 0.79)\end{array}$} & \multirow{2}{*}{$\begin{array}{l}121 \\
(1 \mathrm{RCT})\end{array}$} & \multirow{2}{*}{$\begin{array}{l}\oplus \oplus \oplus \ominus \\
\text { MODERATE }\end{array}$} & \multirow{2}{*}{ Based on one study. } \\
\hline $\begin{array}{l}\text { (1) Washcloth with cleansing, moisturis- } \\
\text { ing, and protecting properties (A) versus } \\
\text { water and pH neutral soap (B) }\end{array}$ & 259 per 1.000 & $\begin{array}{l}80 \text { per } 1.000 \\
\text { (31 to } 204)\end{array}$ & & & & \\
\hline $\begin{array}{l}\text { Number of participants with IAD } \\
\text { (new) }\end{array}$ & & & & & & $\begin{array}{l}\text { No data for this outcome were } \\
\text { reported in the eligible studies. }\end{array}$ \\
\hline $\begin{array}{l}\text { Number of participants not satisfied } \\
\text { with treatment }\end{array}$ & & & & & & $\begin{array}{l}\text { No data for this outcome were } \\
\text { reported in the eligible studies. }\end{array}$ \\
\hline $\begin{array}{l}\text { Number of participants with pain due } \\
\text { to IAD }\end{array}$ & & & & & & $\begin{array}{l}\text { No data for this outcome were } \\
\text { reported in the eligible studies. }\end{array}$ \\
\hline $\begin{array}{l}\text { Number of participants with pain due } \\
\text { to skin care product or procedure }\end{array}$ & & & & & & $\begin{array}{l}\text { No data for this outcome were } \\
\text { reported in the eligible studies. }\end{array}$ \\
\hline $\begin{array}{l}\text { Adverse reaction due to the skin care } \\
\text { product or procedure, e.g. skin irrita- } \\
\text { tion, rash, itching, allergic } \\
\text { reaction }\end{array}$ & & & & & & $\begin{array}{l}\text { No data for this outcome were } \\
\text { reported in the eligible studies. }\end{array}$ \\
\hline Incremental cost-effectiveness & & & & & & $\begin{array}{l}\text { No data for this outcome were } \\
\text { reported in the eligible studies. }\end{array}$ \\
\hline
\end{tabular}




\begin{tabular}{|c|c|c|c|c|c|c|}
\hline \multicolumn{7}{|c|}{$\begin{array}{l}{ }^{*} \text { The risk in the intervention group (and its } 95 \% \text { confidence interval) is based on the assumed risk in the } \\
\text { its } 95 \% \mathrm{CI} \text { ). } \\
\text { CI: confidence interval; IAD: incontinence-associated dermatitis; OR: odds ratio; RR: risk ratio }\end{array}$} \\
\hline \multicolumn{7}{|c|}{$\begin{array}{l}\text { GRADE Working Group grades of evidence } \\
\text { High quality: We are very confident that the true effect lies close to that of the estimate of the effect. } \\
\text { Moderate quality: We are moderately confident in the effect estimate: The true effect is likely to be close to the estimate of the effect, but there is a possibility that it is sub- } \\
\text { stantially different. } \\
\text { Low quality: Our confidence in the effect estimate is limited: The true effect may be substantially different from the estimate of the effect. } \\
\text { Very low quality: We have very little confidence in the effect estimate: The true effect is likely to be substantially different from the estimate of effect. }\end{array}$} \\
\hline $\begin{array}{l}\text { Summary of findings } 3 \text {. Any } n \\
\text { product }\end{array}$ & thod of applic & ion of a topical s & kin care produc & versus anoth & nethod of appl & ation of the topical skin care \\
\hline \multicolumn{7}{|c|}{$\begin{array}{l}\text { Any method of application of a topical skin care product versus another } \\
\text { method of application of the topical skin care product }\end{array}$} \\
\hline \multicolumn{7}{|c|}{$\begin{array}{l}\text { Patient or population: adults with incontinence } \\
\text { Setting: } \\
\text { Intervention: any method of application of a topical skin care product } \\
\text { Comparison: any other method of application of the topical skin care product }\end{array}$} \\
\hline \multirow[t]{2}{*}{ Outcomes } & $\begin{array}{l}\text { Anticipated ab } \\
(95 \% \mathrm{Cl})\end{array}$ & lute effects* & \multirow[t]{2}{*}{$\begin{array}{l}\text { Relative effect } \\
(95 \% \mathrm{CI})\end{array}$} & \multirow{2}{*}{$\begin{array}{l}\text { № of partici- } \\
\text { pants } \\
\text { (studies) }\end{array}$} & \multirow{2}{*}{$\begin{array}{l}\text { Quality of the } \\
\text { evidence } \\
\text { (GRADE) }\end{array}$} & \multirow[t]{2}{*}{ Comments } \\
\hline & $\begin{array}{l}\text { Risk with any } \\
\text { unstructured } \\
\text { skin care pro- } \\
\text { cedure (B) }\end{array}$ & $\begin{array}{l}\text { Risk with } \\
\text { any skin care } \\
\text { procedure } \\
\text { (method or fre- } \\
\text { quency of ap- } \\
\text { plication) (A) }\end{array}$ & & & & \\
\hline \multicolumn{3}{|l|}{$\begin{array}{l}\text { Number of participants with } \\
\text { IAD (residual, i.e. not healed) }\end{array}$} & \multicolumn{4}{|r|}{$\begin{array}{l}\text { No data for this outcome were report- } \\
\text { ed in the eligible studies. }\end{array}$} \\
\hline $\begin{array}{l}\text { Number of participants with } \\
\text { IAD (new) }\end{array}$ & & & & & & $\begin{array}{l}\text { No data for this outcome were report- } \\
\text { ed in the eligible studies. }\end{array}$ \\
\hline \multicolumn{3}{|l|}{$\begin{array}{l}\text { Number of participants not sat- } \\
\text { isfied with treatment }\end{array}$} & \multicolumn{4}{|r|}{$\begin{array}{l}\text { No data for this outcome were report- } \\
\text { ed in the eligible studies. }\end{array}$} \\
\hline
\end{tabular}




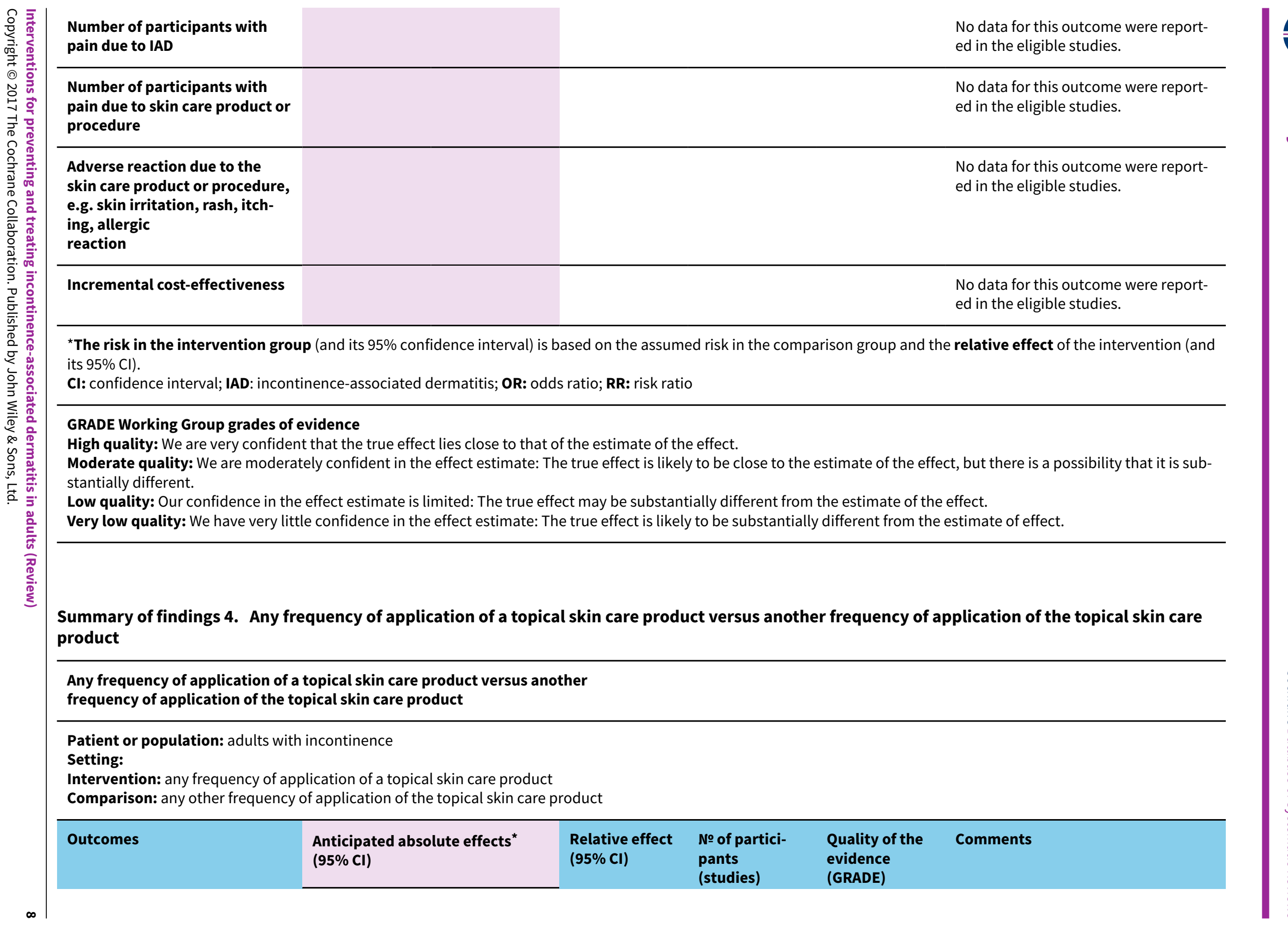




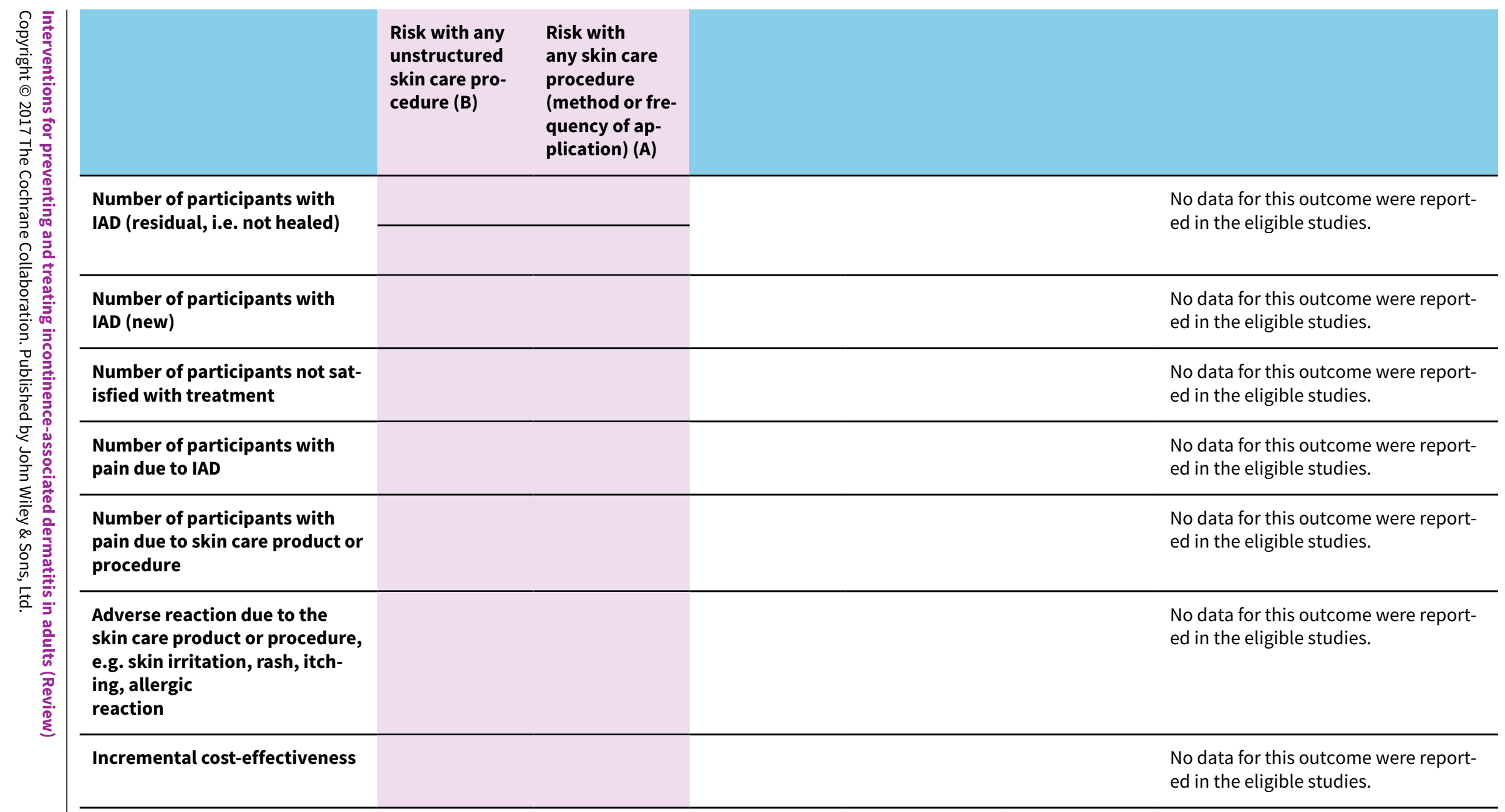

${ }^{\star}$ The risk in the intervention group (and its $95 \%$ confidence interval) is based on the assumed risk in the comparison group and the relative effect of the intervention (and its $95 \% \mathrm{Cl})$.

Cl: confidence interval; IAD: incontinence-associated dermatitis; OR: odds ratio; RR: risk ratio

\section{GRADE Working Group grades of evidence}

High quality: We are very confident that the true effect lies close to that of the estimate of the effect.

Moderate quality: We are moderately confident in the effect estimate: The true effect is likely to be close to the estimate of the effect, but there is a possibility that it is substantially different.

Low quality: Our confidence in the effect estimate is limited: The true effect may be substantially different from the estimate of the effect.

Very low quality: We have very little confidence in the effect estimate: The true effect is likely to be substantially different from the estimate of effect. 


\section{B A C K G R O U N D}

\section{Description of the condition}

Incontinence is defined as the complaint of any involuntary loss of urine (urine incontinence) or faecal material (faecal incontinence) or both (double incontinence) (ISC 2009). Incontinence is a widespread problem in all healthcare settings (Du Moulin 2008; Macmillan 2004). Figures from studies on the prevalence of urinary/ faecal incontinence vary, mainly attributable to the population type and the study protocol used. With prevalence estimates between $10 \%$ and $15 \%$ for faecal incontinence measured in communitydwelling adults (Macmillan 2004; Shamliyan 2007), and up to $46 \%$ for urinary incontinence measured in older, home care patients (Du Moulin 2008), it is clear that incontinence care is an important task for clinicians, patients, and their carers. Incontinence can lead to numerous complications. One of the most common complications is perineal skin breakdown (Gray 2010; Langemo 2011).

\section{Incontinence-associated dermatitis}

We can define incontinence-associated dermatitis (IAD) as erythema and oedema of the surface of the skin, sometimes accompanied by bullae with serous exudates, erosion, or secondary cutaneous infection. Skin exposed to moisture, such as faecal or urinary incontinence, is susceptible to the development of IAD. Gray 2007 defined IAD as a skin inflammation manifested as redness with or without blistering, erosion, or loss of the skin barrier function that occurs as a consequence of chronic or repeated exposure of the skin to urine or faecal matter. IAD is the result of top-down damage to the skin due to:

- tissue intolerance (e.g. age, nutrition);

- an affected perineal environment (e.g. due to incontinence); and - problems with toileting ability (e.g. restraints) (Beeckman 2009).

The most important aetiologic factors are urinary, faecal, and double incontinence (Beeckman 2014). Faecal incontinence has been identified as a particularly high risk factor for the development of IAD, with liquid faecal matter as the most severe irritant (Beeckman 2009).

Traditionally, IAD has received little attention as a distinct skin disorder, and it is regularly confused with Category/Stage I and II pressure ulcers (Beeckman 2010; Beeckman 2014). The clinical presentation of IAD ranges from erythema (with or without loss of skin) to cutaneous infections (such as candidiasis) (Beeckman 2007). IAD is often associated with redness, rash, or vesiculation (Gray 2007). Although the lesions are superficial, they are likely to become slightly deeper when an infection occurs. In contrast, the clinical signs of pressure ulcers range from non-blanchable erythema of the intact skin, over partial/full thickness skin loss, to tissue destruction involving skin, subcutaneous fat, muscle, and bone (NPUAP 2014). A recent systematic review and metaanalysis by Beeckman 2014 confirmed incontinence (and moisture in general) and IAD as an important risk factor for pressure ulcer development.

\section{Prevalence}

Studies report prevalence figures of IAD between $5.6 \%$ to $50.0 \%$, with incidence rates between $3.4 \%$ and $25.0 \%$, depending on the type of setting and population studied (Gray 2007). Most epidemiological studies were performed in small sample, single- centre, and long-term care settings (Gray 2012). A study on the prevalence of IAD among hospitalised acute care patients in the United States $(n=976)$ reported a prevalence of $27 \%$ (Junkin 2007). A study using a large sample $(n=3713)$ of incontinent participants reported an overall IAD prevalence across different healthcare settings in two European countries of $6.1 \%$ (Kottner 2014). Approximately one-third of people with faecal incontinence develop IAD (Gray 2002). Incontinence, and subsequent skin breakdown, have a considerable effect on patients' physical and psychological well-being (Newman 2007; Sibbald 2003).

\section{Aetiology}

The aetiology of IAD is complex and related to both chemical and physical irritation of the skin (Beeckman 2009). Ananthapadmanabhan 2004 demonstrated that a rise in $\mathrm{pH}$ (caused by urine and faeces) increases stratum corneum swelling and alterations in lipid rigidity, thus increasing the permeability of the skin and reducing the barrier function. Furthermore, a more alkaline $\mathrm{pH}$ increases the risk of bacterial colonisation, and thus cutaneous infections. Friction (physical irritation) increases when the skin rubs over clothing, diapers/pads, and bed or chair surfaces. The combination of chemical and physical irritation results in a weakened skin. If these mechanisms affect the integrity of the skin recurrently, IAD and further skin breakdown are likely to develop (Beeckman 2009).

To date, there has been a lack of rigorously performed research addressing the effectiveness of different skin care regimens to prevent or treat IAD. A number of studies compared the use and effects of different types of skin regimens, but design weaknesses seem to be common. Tentative evidence indicates that key prevention recommendations include structured skin care regimens including gentle cleansing, moisturising, and the application of skin protectants or moisture barriers.

\section{Description of the intervention}

Current prevention of IAD consists of skin care interventions such as skin cleansing, moisturising/skin conditioning, and the application of skin protectants/barriers. Treatment includes protecting the skin from further exposure to irritants, establishing a healing environment, and eradicating skin infections. A plethora of overthe-counter and prescribed products for cleansing, moisturising, and protecting (creams, ointments, pastes, film layers, etc.) as well as procedures to apply the products (for example, frequency and method of application) are currently available. The same products are used for patients with and without IAD. Topical antibiotics and antimycotics are additionally used to eradicate skin infections.

\section{How the intervention might work}

We considered three main interventions (cleansing, moisturising, protection) using topical skin care products in this Cochrane Review. We also investigated different procedures for their use, such as frequency or method of application.

\section{Cleansing}

Skin cleansing aims to remove dirt, debris, and micro-organisms on the skin surface, usually using water alone or in combination with skin cleansers. 


\section{Moisturising}

Skin moisturising aims to repair or augment the skin's barrier, retain and/or increase its water content, reduce transepidermal water loss, and restore or improve the intercellular lipid structure.

\section{Protectants and barriers}

The primary purpose of a skin protectant is to prevent skin breakdown by providing an impermeable or semipermeable barrier on the skin, thus preventing or reducing the penetration of water and chemical and biological irritants found in stool and urine.

\section{Why it is important to do this review}

A wide range of topical skin care products and procedures are currently used in practice. Despite their widespread use, little is known about their efficacy and effectiveness. We conducted this review to clarify the effects of various products and skin care protocols to prevent and treat IAD in adults.

\section{OB JECTIVES}

The objective of this review was to assess the effectiveness of various products and procedures to prevent and treat incontinence-associated dermatitis in adults.

\section{METHODS}

\section{Criteria for considering studies for this review}

\section{Types of studies}

We included all RCTs and quasi-RCTs if one arm of the trial included a structured and well-defined procedure (including a standard frequency, method, and product selection) or a skin care product used to prevent or treat incontinence-associated dermatitis (IAD). We compared these with other structured skin care procedures or unstructured (not standardised) procedures or other products, methods, or frequencies used to prevent or treat IAD.

\section{Types of participants}

Studies involving male or female participants, or both, over 18 years of age, in any healthcare setting, with or without IAD (defined as erythema and oedema of the surface of the skin, sometimes accompanied by bullae with serous exudates, erosion, or secondary cutaneous infection) were eligible for inclusion.

\section{Types of interventions}

We included trials of topical skin care products such as skin cleansers, moisturisers, and skin protectants of different compositions and skin care procedures aiming to prevent or treat IAD in this Cochrane Review. We examined the following comparisons.

1. Any topical skin care product versus another topical skin care product.

a. Cleansing products

b. Moisturising products

c. Protectants and barriers

2. Any skin care procedure (method or frequency of application) versus any unstructured skin care procedure.

3. Any method of application of a topical skin care product versus another method of application of the topical skin care product.
4. Any frequency of application of a topical skin care product versus another frequency of application of the topical skin care product.

\section{Types of outcome measures}

\section{Primary outcomes}

1. Number of participants with incontinence-associated dermatitis (IAD) (residual, i.e. not healed)

2. Number of participants with IAD (new) (only suitable to evaluate interventions for preventing IAD)

3. Number of participants not satisfied with treatment

\section{Secondary outcomes}

1. Participants' observations

a. Number of participants with pain due to IAD

b. Number of participants with pain due to skin care product or procedure

2. Quantification of symptoms (objective measures)

a. Surface affected by IAD (measurement of size of lesion)

3. Clinicians' observations

a. Number of participants with IAD not improved (only suitable to evaluate interventions for treating IAD)

b. Number of participants not complying/discontinuing treatment (acceptability and tolerance)

4. Quality of life

a. Condition-specific

b. Generic (e.g. SF-36, EQ-5D, Manchester Short Assessment of Quality of Life)

c. Psychosocial

5. Economic data

a. Cost of products

b. Staff time

c. Incremental cost-effectiveness

6. Adverse effects (of the interventions)
a. Adverse reaction due to the skin care product or procedure, e.g. skin irritation, rash, itching, allergic reaction
b. Normal flora disruption
c. Toxicity

7. Other outcomes (non-prespecified outcomes judged important when performing the review)
a. IAD severity
b. Number of participants with IAD completely healed
c. Number of participants with bacterial or fungal infection

\section{Search methods for identification of studies}

We undertook a two-step search strategy to identify relevant literature. Firstly, we searched electronic databases. Secondly, we searched other sources, such as conference proceedings. We imposed no restrictions, such as language or publication status, on the searches.

\section{Electronic searches}

This review drew on the search strategy developed for the Cochrane Incontinence Group. We identified relevant trials from the Cochrane Incontinence Group Specialised Trials Register. For more details of the search methods used to build the Specialised Register, 
please see the Group's module in the Cochrane Library. The register contains trials identified from the Cochrane Central Register of Controlled Trials (CENTRAL), MEDLINE, MEDLINE In-Process, MEDLINE Epub Ahead of Print, CINAHL, ClinicalTrials.gov, World Health Organisation International Clinical Trials Registry Platform (WHO ICTRP), and handsearching of journals and conference proceedings. Many of the trials in the Cochrane Incontinence Group Specialised Register are also contained in CENTRAL.

The terms used to search the Cochrane Incontinence Group Specialised Register are given in Appendix 1. The date of the last search was 28 September 2016.

Additionally, as the condition can be very poorly described, especially in the older literature, we searched the following electronic databases.

- CENTRAL on OvidSP 2015, Issue 4 was searched on 27 May 2015. The search strategy is given in Appendix 2.

- MEDLINE on OvidSP (from January 1946 to May Week 3, 2015) was searched on 27 May 2015. The search strategy is given in Appendix 2.

- MEDLINE In-Process on OvidSP (covering 26 May 2015) was searched on 27 May 2015. The search strategy is given in Appendix 2.

- Cumulative Index for Nursing and Allied Health (CINAHL), was searched through the EBSCO Interface, from inception (December 1981) to the most recent version available (27 May 2015) on 28 May 2015. The search strategy is given in Appendix 3.

- Web of Science (WoS) (on Web of Knowledge) was searched from inception of the constituent databases to the most recent available versions, on 28 May 2015. The search was limited to the WoS Core Collection. The search strategy is given in Appendix 4.

\section{Searching other resources}

The review authors contacted authors of trials included in this Cochrane Review and asked them if they knew of any other RCTs possibly relevant for this review. We also contacted experts in the field to identify additional trials.

We handsearched the following conference proceedings: European Pressure Ulcer Advisory Panel (2000 to July 2015), European Wound Management Association (2001 to July 2015), and Wound, Ostomy and Continence Nurses Society (1994 to July 2015).

We screened the reference lists of all included trials and other relevant literature reviews to identify additional papers.

\section{Data collection and analysis}

\section{Selection of studies}

Two review authors (NVD and KVDB) independently screened titles and abstracts of all identified records. They retrieved and further checked for inclusion the full text of all potentially relevant records. NVD and KVDB sought the advice of a third review author (AVL) to resolve disagreements and documented reasons for exclusion of the records read in full.

\section{Data extraction and management}

Two review authors (SW and JK) independently extracted data from the included trials. We developed a standardised form to use in this review. We pilot-tested the extraction form to identify whether we should collect additional data or improve the form.

The standardised form included the following data to be extracted: aim, design, setting, sample characteristics, description of intervention and comparison, outcome, and limitations. If necessary, we contacted the authors of the included studies to request additional information.

\section{Assessment of risk of bias in included studies}

We evaluated the methodological quality of all included articles using Cochrane's 'Risk of bias' tool. This includes the following: selection bias, performance bias, detection bias, attrition bias, reporting bias, and other bias (bias not covered elsewhere). We assigned each domain a judgement of 'low risk', 'high risk', or 'unclear risk' of bias, which we interpreted in accordance with Chapter 8 of the Cochrane Handbook for Systematic Reviews of Interventions (Higgins 2011). Five review authors (MG, LS, JK, SW, DDM) independently assessed the risk of bias. If necessary, these authors sought the advice of DB to resolve disagreements.

\section{Measures of treatment effect}

We calculated risk ratios (RRs) with a 95\% confidence interval (CI) for binary outcomes and mean differences (MDs) with a 95\% Cl for continuous data.

\section{Unit of analysis issues}

The unit of analysis of RCTs and quasi-RCTs were individual participants. If appropriate, we used the following choices for other designs.

- Cross-over design: we planned to use the first treatment period.

- Cluster-RCTs: we took into account the clustering effect.

\section{Dealing with missing data}

The review authors contacted the authors of studies with missing data to request additional information. We used the intentionto-treat analysis (defined as analysed in the group to which the participants were randomised whether or not they received the intervention) and available case analysis (that is data as reported by trialists without imputation for missing data).If data were missing to the extent that we could not include the trial in the analysis, we presented the results in a narrative way. If there was evidence of differential dropout, we gave consideration to imputation of the missing data.

\section{Assessment of heterogeneity}

We planned to combine the studies in a meta-analysis if the clinical and methodological heterogeneity were acceptable. We judged the clinical heterogeneity based on population and intervention type. Due to large clinical and methodological heterogeneity, the data were not suitable for meta-analysis.

We planned to assess the statistical heterogeneity using the $\mathrm{Chi}^{2}$ test at a significance level of 0.10 and calculate the $I^{2}$ statistic to quantify the heterogeneity. We would interpret the $\mathrm{I}^{2}$ in accordance with Chapter 9 of the Cochrane Handbook for Systematic Reviews of Interventions (Higgins 2011), and we would explore the source of heterogeneity using subgroup and sensitivity analysis. However, we did not perform a Chi ${ }^{2}$ test nor calculated the $\mathrm{I}^{2}$ statistic because a meta-analysis was not suitable. 


\section{Assessment of reporting biases}

A comprehensive search for eligible studies and alertness for duplication of data minimised the potential impact of publication and reporting bias. It was not possible to perform a funnel plot to assess reporting bias because of non-comparable designs and outcomes.

\section{Data synthesis}

We entered data of all the trials in the software program Review Manager (RevMan 2014).

We planned to use a fixed-effect model when pooling the data, except for studies with an $\mathrm{I}^{2}$ equal to or greater than $75 \%$, in which case we would use a random-effects model. However, due to large clinical and methodological heterogeneity, it was not suitable to pool data. We presented the results in a narrative way.

We rated the quality of the evidence by using the software program GRADEpro (GRADEpro GDT 2014). We assessed the relevance of the effect of the interventions based on a judgment of each participant-important outcome separately. GRADE allowed us to assess the quality of the body of evidence by taking into account five considerations: study limitations, consistency of effect, imprecision, indirectness, and publication bias (Guyatt 2011).The GRADE working group strongly recommends including up to seven potentially participant-important outcomes in a systematic review (Guyatt 2011). Based on discussion within the research group, the review authors selected the following potentially important participant outcomes.

1. Number of participants with IAD (residual).

2. Number of participants with IAD (new).

3. Number of participants not satisfied with treatment.

4. Number of participants with pain due to IAD.

5. Number of participants with pain due to skin care product or procedure.

6. Adverse reaction due to the skin care product or procedure, e.g. skin irritation, rash, itching, allergic reaction.

7. Incremental cost-effectiveness.

We presented participant-important outcomes in Summary of findings for the main comparison and Summary of findings 2.

\section{RES U L T S}

\section{Description of studies}

\section{Results of the search}

The literature search produced 4089 records, from which we further assessed 40 full-text articles for eligibility. Fourteen (quasi) randomised trials met the inclusion criteria for this review. One of these studies is awaiting classification, as Japanese translation is needed (Kajii 2005; Characteristics of studies awaiting classification). Additionally there were two ongoing studies (NCT02570139 2015; NCT02690753 2016). The PRISMA diagram in Figure 1 presents the flow of the literature search. 
Figure 1. PRISMA study flow diagram.

120 records
identified through
searching the
Incontinence
Group Specialised
Register

4125 records identified through searching other electronic databases
3 additional records identified through other sources

4049 records excluded

24 full-text articles excluded, with reasons given in the

Characteristics of excluded studies table 
Figure 1. (Continued)

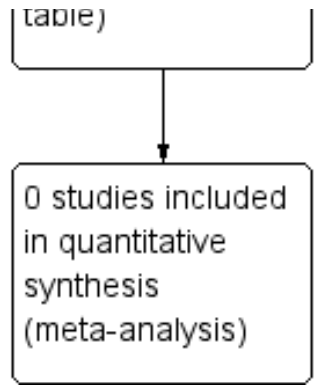

\section{Included studies}

We included 13 (quasi-)RCTs in the qualitative synthesis (see Characteristics of included studies). The total number of participants included in the analyses was 1295 .

\section{Design}

Eleven trials had a parallel group design. One trial had a cluster design (Beeckman 2011). One trial had a cross-over design without a washout period between treatments (Byers 1995).

\section{Settings}

Nine trials were performed at single centres. Of these, six were located in the United States, one in the Philippines, one in China, and one in the Netherlands. Five of these single-centre studies were conducted in hospitals and four in nursing homes.

One trial was conducted on geriatric wards of hospitals from one health service trust in the United Kingdom.

Of the three remaining trials, one was conducted in 11 nursing homes in Belgium, one in 22 nursing homes in the Netherlands, and one in five long-term care centres in the United States.

\section{Participants}

The mean age of the participants varied between 59 and 89 years across all studies. In more than half of the trials $(7 / 13)$, the mean age was over 80 years. In the Lewis-Byers 2002 trial, conducted in a nursing home, the participants were between 41 and 105 years old. Two other trials, of which one was conducted in a hospital and one in a nursing home, did not report data on participants' age (Dieter 2006; Kennedy 1996).

Most of the trials $(n=10)$ recruited participants with all types of incontinence. In one trial, participants with faecal incontinence were included (Wang 2011). In another trial, only female participants with both urinary and faecal incontinence were included (Byers 1995). In a last trial, the type of incontinence was not reported (Anthony 1987).

In six trials, more than half of the participants showed neither redness nor skin erosion. Two trials included only participants without redness or skin erosion (Brunner 2012; Byers 1995). Three trials included only participants with redness and/or skin erosion (Baatenburg de Jong 2004; Buckley 2014; Wang 2011). The two remaining trials did not report the proportion of participants with skin problems in the perineal environment (Dieter 2006; Schoonhoven 2015).

\section{Interventions}

Eight trials compared the application of a topical skin care product versus another topical skin care product for the prevention and/or treatment of incontinence-associated dermatitis (IAD) (first comparison, see Types of interventions). Because the main function of the products (moisturising versus skin protecting) was not always clear, we classified all topical skin care products broadly into skin cleansers and leave-on products. Leave-on products include moisturisers, skin protectants/barriers, and other functions, whether combined or not into one product.

- Two trials compared no-rinse skin cleansers with soap and water for the prevention (and treatment) of IAD (Cooper 2001; Byers 1995).

- Eight trials compared various leave-on products (moisturisers, skin protectants/barriers, whether combined or not into one product) as follows.

- One trial compared Sudocrem with a standard zinc oxide cream for the prevention and treatment of IAD (Anthony 1987).

- A second trial compared a zinc oxide oil with a filmforming skin product for the prevention and treatment of IAD (Baatenburg de Jong 2004).

- A third trial compared a no-rinse skin cleanser and a leaveon product with a washcloth with cleansing, moisturising and skin protecting properties for the prevention and treatment of IAD (Dieter 2006).

- A fourth trial compared a no-rinse skin cleanser and a skin cream with soap and water combined with a lotion for the prevention and treatment of IAD (Lewis-Byers 2002).

- A fifth trial compared a no-rinse skin cleanser and moisturiser combined with a film-forming skin product with a cleansing/ moisturising/skin protecting washcloth for the prevention of IAD (Brunner 2012).

- A sixth trial compared Desitin and Calmoseptine, two commercial zinc oxide based products, for the treatment of IAD (Buckley 2014).

- A seventh trial compared a zinc oxide cream with a petrolatum ointment and a film-forming skin product for the treatment of IAD (Kennedy 1996).

- An eighth trial compared Dermlin and Genetime for the treatment of IAD (Wang 2011).

Two trials compared a structured skin care procedure with an unstructured skin care procedure (second comparison, see Types of interventions). 
- One trial compared a washcloth with cleansing, moisturising and protecting properties with soap and water for the prevention and treatment of IAD (Beeckman 2011).

- One trial compared a washcloth impregnated with a lotion with soap and water for the prevention and treatment of any skin abnormalities and significant skin lesions (Schoonhoven 2015).

Two trials compared different frequencies of application of topical skin care products (fourth comparison, see Types of interventions).

- One trial compared two frequencies of a structured skin care procedure, including a skin cleanser and a leave-on product, for the prevention and treatment of IAD: every six versus 12 hours (Conley 2014).

- One trial compared three frequencies of the application of a filmforming skin product in the treatment of IAD: every 24 and 48 hours versus 72 hours for the treatment of IAD (Kennedy 1996).

\section{Length of treatment}

Most trials $(n=9)$ had a treatment period of 15 days or less. In three trials, nursing home residents were treated for three weeks (Lewis-Byers 2002), six weeks (Schoonhoven 2015), or three months (Beeckman 2011). In one trial the length of treatment was not reported (Dieter 2006).

\section{Sample size}

Four trials had a sample size of 50 or less participants (Baatenburg de Jong 2004; Byers 1995; Lewis-Byers 2002; Kennedy 1996). In six trials, the sample size varied between 50 and 100 (Anthony 1987; Brunner 2012; Conley 2014; Cooper 2001; Dieter 2006; Wang 2011). In three trials, more than 100 participants were included (Beeckman 2011; Buckley 2014; Schoonhoven 2015). The smallest sample size was 10 (Byers 1995), and the largest 450 (Schoonhoven 2015). Only the trial of Beeckman 2011, with a sample size of 141 participants, mentioned that this sample size was sufficient for a statistical power of $0.85(\alpha=0.05)$.

\section{Ongoing Studies}

There are two ongoing studies (NCT02570139 2015; NCT02690753 2016).

\section{Excluded studies}

In total, we excluded 24 trials from this review (see Characteristics of excluded studies), for the following reasons.

- Six trials were not quasi-RCTs (Bliss 2007; Dealey 1995; Holroyd 2014; Kyung 2014; Lyder 1992, Zehrer 2004).

- Twelve trials did not encompass any topical skin care product (Al-Samarrai 2007; Bates-Jensen 2003; Bennett 1998; Brown 1994; Denat 2011; Fader 2003; Leiby 1994; Netta-Turner 2008; Pittman 2012; Shin 2012; Su 2015; Sugama 2012).

- One trial was not developed for the prevention or treatment of IAD (Pinedo 2012).

- One trial was restricted to the trial protocol (Bauer 2007).

- Two trials included participants younger than 18 years (Iraji 2003; James 1975).

- One trial concerned the effectiveness of implementation strategies not effectiveness of products/procedures (Harries 2016)
- One trial was finished prematurely, no reliable results were possible (NCT02475512 2015).

\section{Risk of bias in included studies}

\section{Allocation}

The risk of bias associated with random sequence generation was low in five trials (Baatenburg de Jong 2004; Beeckman 2011; Buckley 2014; Cooper 2001; Schoonhoven 2015), high in three trials (Conley 2014; Dieter 2006; Lewis-Byers 2002), and remained unclear in five trials (Anthony 1987; Brunner 2012; Byers 1995; Kennedy 1996; Wang 2011). Baatenburg de Jong 2004 used a computerised randomisation list provided by an independent biostatistics centre. Schoonhoven 2015 used a computerised randomisation list set up by an independent statistician. Beeckman 2011 and Buckley 2014 performed a computerised randomisation at their own research centre. Cooper 2001 used unmarked envelopes to randomise patients (first research site) or wards (other research sites). Conley 2014 assigned participants enrolled on even numbered days to the intervention group and those enrolled on odd numbered days to the control group. Dieter 2006 assigned participants based on the last digit of their medical record number. Lewis-Byers 2002 assigned participants in odd numbered rooms to the trial protocol and participants in even numbered rooms to the control group. The methods used by Conley 2014, Dieter 2006 and Lewis-Byers 2002 were associated with a high risk of bias because allocation could be foreseen.

The risk of bias associated with allocation concealment was low in one trial (Buckley 2014), high in three trials (Conley 2014; Dieter 2006; Lewis-Byers 2002), and remained unclear in the remaining nine trials. In the study of Buckley 2014, an independent surgical research unit, not linked to the trialists, performed the treatment allocation. Conley 2014 used odd and even numbered days for treatment allocation. Dieter 2006 used the last digit of medical record numbers for treatment allocation. Lewis-Byers 2002 used odd and even numbered rooms for treatment allocation. The methods used by Conley 2014, Dieter 2006 and Lewis-Byers 2002 were associated with a high risk of bias because allocation could be foreseen.

\section{Blinding}

The risk of performance bias remained unclear in one trial (Anthony 1987). Anthony 1987 mentioned a double-blind design but the researchers provided no further details. Blinding of participants and personnel was not possible in 12 trials due to visual differences in appearance and use of the skin care products.

The risk of detection bias was low in two trials (Buckley 2014; Cooper 2001), unclear in three trials (Anthony 1987; Dieter 2006; Wang 2011), and high in the remaining eight trials. Cooper 2001 and Buckley 2014 blinded the outcome assessment by asking experts to assess the outcomes using photographs. The Buckley 2014 trial also mentioned the removal of residual ointment using mineral oil to avoid traces of product being visible on the photographs. Anthony 1987 mentioned a double-blind design but provided no further details. In the remaining trials no information on the assessment procedure was given, or the assessment was not blinded.

\section{Incomplete outcome data}

The risk of attrition bias due to incomplete outcome data was low in six trials (Baatenburg de Jong 2004; Buckley 2014; Byers 1995; 
Conley 2014; Cooper 2001; Lewis-Byers 2002), high in two trials (Anthony 1987; Brunner 2012), and unclear in the remaining five trials (Beeckman 2011; Dieter 2006; Kennedy 1996; Schoonhoven 2015; Wang 2011).

\section{Selective reporting}

The risk of reporting bias due to selective reporting was low in eight trials (Baatenburg de Jong 2004; Beeckman 2011; Buckley 2014; Byers 1995; Conley 2014; Cooper 2001; Lewis-Byers 2002; Schoonhoven 2015), high in four trials (Anthony 1987; Brunner 2012; Dieter 2006; Kennedy 1996), and unclear in one trial (Wang 2011). Anthony 1987 did not report the results in sufficient detail (e.g. no parameters of erythema readings, only proportions of participants with change in red band). Brunner 2012 did not report the statistical methods clearly and provided only $P$ values for some results. Furthermore, Brunner 2012 did not give any reason for using a restricted sample size to study the time for skin breakdown. Dieter 2006 and Kennedy 1996 did not report the statistical methods and provided no $P$ values.

\section{Other potential sources of bias}

One trial used a cross-over design without a washout period between interventions (Byers 1995). Consequently, bias could have been introduced from a carry-over effect.

At least five trials were sponsored by industry (Baatenburg de Jong 2004; Buckley 2014; Byers 1995; Cooper 2001; Kennedy 1996). Concerning the trial of Baatenburg de Jong 2004, the industrial company did the randomisation and data analysis. Concerning the trial of Kennedy 1996, one of the authors was a member of the company delivering one of the trial products. In another trial the corresponding author was a member of the company delivering the trial products (Lewis-Byers 2002). It was not clear how the involvement of industry may have influenced the results.

Detailed results of the risk of bias are presented in Characteristics of included studies and in Figure 2 and Figure 3.

Figure 2. Risk of bias graph: review authors' judgements about each risk of bias item presented as percentages across all included studies.

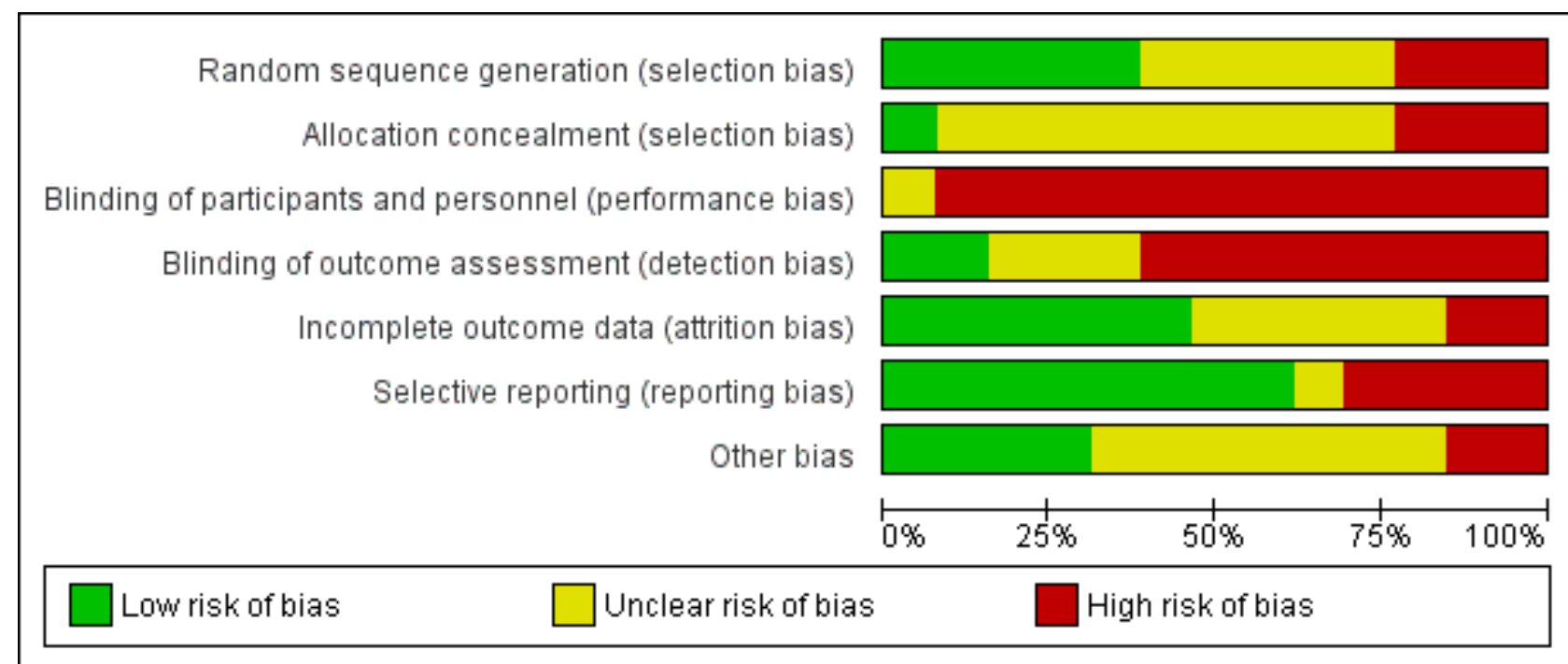


Figure 3. Risk of bias summary: review authors' judgements about each risk of bias item for each included study.

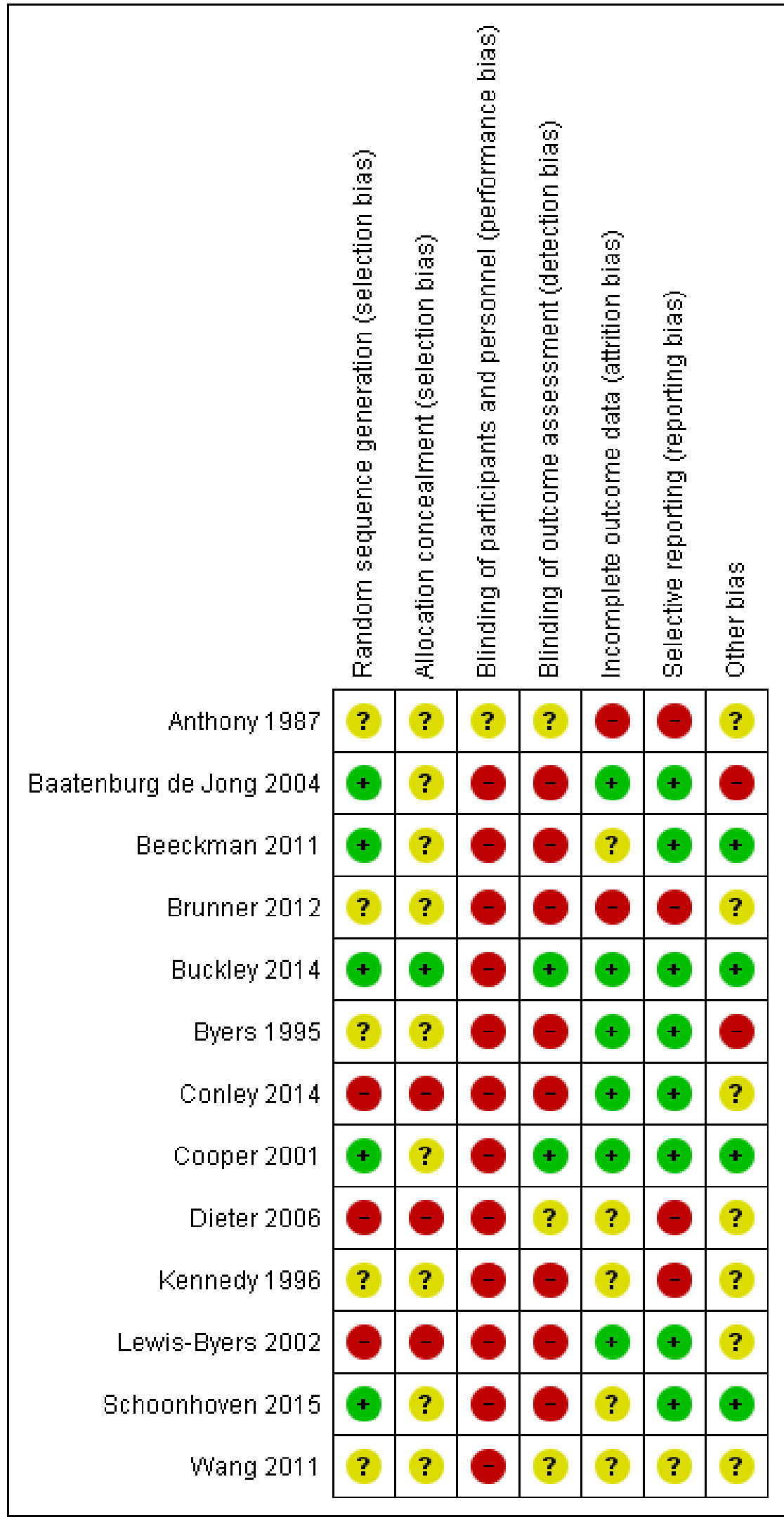




\section{Effects of interventions}

See: Summary of findings for the main comparison Any topical skin care product versus another topical skin care product; Summary of findings 2 Any skin care procedure (method or frequency of application) versus any unstructured skin care procedure; Summary of findings 3 Any method of application of a topical skin care product versus another method of application of the topical skin care product; Summary of findings 4 Any frequency of application of a topical skin care product versus another frequency of application of the topical skin care product

In this section, we described separately the data of included trials because of variation in tested skin care products or procedures and reported outcomes. The tables in Characteristics of included studies present a more detailed description of the trials. If possible, we entered the data in Review Manager 5 to calculate risk ratios (RRs) and confidence intervals (Cls) for use in this section (RevMan 2014). The tables in Data and analyses present an overview of all relevant outcomes measured in the included studies and the numbers of studies measuring each outcome. We did not present effect sizes (totals and subtotals), as we did not perform any metaanalyses.

\section{Any topical skin care product versus another topical skin care product}

For the same reason as described in Included studies, the topical skin care products are divided into skin cleansers and leaveon products. Leave-on products consist of moisturisers, skin protectants/barriers, and other functions, whether combined or not, into one product.

\section{Skin cleansers}

Two trials compared a skin cleanser with soap and water (Byers 1995; Cooper 2001).

The Cooper 2001 trial compared the use of the skin cleanser Clinisan with the standard use of soap and water for the prevention and treatment of incontinence-associated dermatitis (IAD). Clinisan consists of a surfactant, emollients, dimethicone, an antibacterial agent, and perfume, and has a $\mathrm{pH}$ of 5.5 .

The Byers 1995 trial compared the use of the skin cleanser Triple Care Cleanser with the standard use of soap and water for the prevention of IAD in a cross-over trial.

\section{Primary Outcomes}

Number of participants with incontinence-associated dermatitis (IAD) (residual, i.e. not healed)

Not reported.

Number of participants with IAD (new) (only suitable to evaluate interventions for preventing IAD)

The Cooper 2001 trial $(n=87)$ demonstrated that less participants treated with Clinisan developed IAD during 14 days of follow-up. In the intervention group 6/33 (18.2\%) of the elderly developed IAD during the study, and in the control group 15/32 (46.9\%) of the elderly developed IAD during the study. According to Analysis 1.2, this effect was significant in favour of Clinisan (RR 0.39, 95\% Cl 0.17 to 0.87 ; low quality evidence; Summary of findings for the main comparison).
Number of participants not satisfied with treatment

Not reported.

\section{Secondary Outcomes}

Participants' observations

Not reported.

Quantification of symptoms (objective measures)

Not reported.

\section{Clinicians' observations}

Not reported.

\section{Quality of life}

Not reported.

\section{Economic data}

The Byers 1995 trial $(n=10)$ demonstrated that for an episode of urinary incontinence, the mean difference (MD) in cleansing time was 3.87 minutes in favour of the Triple Care Cleanser $(95 \% \mathrm{Cl}-4.31$ to $-3.43 ; \mathrm{P}<0.001$; Analysis 1.4). For an episode of both urinary and faecal incontinence, the MD in cleansing time was 9.68 minutes in favour of the Triple Care Cleanser $(95 \% \mathrm{Cl}-11.71$ to -7.65 ; $\mathrm{P}<$ 0.001 ; Analysis 1.4). The results of this cross-over trial were based on measurements over five treatment periods. The researchers did not provide results for the separate treatment periods. We did not find recent contact details to request more detailed information.

\section{Adverse effects (of the interventions)}

Not reported.

Other outcomes (non-prespecified outcomes judged important when performing the review)

These outcomes were: IAD severity; number of participants with IAD completely healed, and number of participants with bacterial or fungal infection.

Not reported.

\section{Leave-on products (moisturisers, skin protectants/barriers, combined or not)}

Eight trials compared various leave-on products (moisturisers, skin protectants/barriers, whether combined or not into one product) (Anthony 1987; Baatenburg de Jong 2004; Brunner 2012; Buckley 2014; Dieter 2006; Lewis-Byers 2002; Kennedy 1996; Wang 2011).

The Anthony 1987 trial compared two different zinc oxide creams, Sudocrem and a standard zinc oxide cream. Sudocrem is claimed to have antiseptic properties and consists of $15.25 \%$ zinc oxide, $4.0 \%$ hydrous wool fat (hypoallergenic), $1.01 \%$ benzyl benzoate, $0.15 \%$ benzyl cinnamate, and $0.39 \%$ benzyl alcohol. The standard zinc oxide cream consists of $32.0 \%$ zinc oxide, $32.0 \%$ arachis oil, $0.045 \%$ calcium hydroxide, $0.5 \%$ oleic acid, and $8 \%$ wool fat. Both creams were applied liberally to groin and buttocks with each diaper/pad change for 14 days.

The Baatenburg de Jong 2004 trial compared a zinc oxide oil with the film-forming skin product Cavilon No Sting Barrier Film for the prevention and treatment of IAD. The zinc oxide oil was applied in accordance with nursing home protocol and removed 
every morning and evening before re-application, and if necessary during diaper/pad changes. The film-forming skin product was applied every 24,48 , or 72 hours, depending on skin condition and frequency of diaper/pad change.

The Brunner 2012 trial compared the use of a cleansing and moisturising product followed by the application of a filmforming skin product with the use of a washcloth (with cleansing, moisturising, and protecting properties) for the prevention of IAD. The trial products were Cavilon Skin Cleanser, Cavilon No Sting Barrier Film, and Comfort Shield Perineal Care Washcloth Dimethicone 3\%.

The Buckley 2014 trial compared Desitin and Calmoseptine, two zinc oxide based products, for the treatment of IAD. Desitin is a paste consisting of $40 \%$ zinc oxide, lanolin, petrolatum, and cod liver oil. Calmoseptine is an ointment consisting of $20 \%$ zinc oxide, menthol, chlorothymol, glycerine, lanolin, sodium bicarbonate, phenol, and thymol. In each group, one of the zinc oxide products was applied twice daily and after each incontinence episode for six days. In addition, in both groups a structured skin care procedure for the treatment of IAD was applied. The skin care procedure was provided twice daily and as required by incontinence episodes. As part of the skin care procedure, nurses removed wet or soiled diapers/pads, cleansed the skin gently with a polyhexanide wound cleansing solution using gauze pads and soft tissue and applied a thin layer of zinc oxide product prior to putting a new diaper/pad on.

The Dieter 2006 trial compared the combined use of a no-rinse skin cleanser and a leave-on product with the use of a washcloth with cleansing, moisturising, and skin protecting properties for the prevention and treatment of IAD. The researchers did not give the commercial name nor the ingredients of the products studied.

This study was described as an abstract. The outcomes reported were not suitable for this review. The authors did not respond to our request for more information.

The Lewis-Byers 2002 trial compared the combined use of a norinse skin cleanser plus a skin cream with the use of soap and water plus a lotion for the prevention and treatment of IAD. The no-rinse skin cleanser tested was Cavilon Antiseptic Skin Cleanser. The skin cream was Cavilon Durable Barrier Cream. The study authors did not provide the commercial name nor the ingredients of the lotion.

The participants of the first group were cleansed with the Cavilon Antiseptic Skin Cleanser after each incontinent episode, and during the first incontinent episode per shift, a skin cream was applied. The participants of the second group were cleansed with soap (liquid or bar) and a disposable washcloth and water followed by the application of a lotion after each incontinence episode. Staff time per participant per day was measured for gathering supplies, setting supplies, cleansing participants, and application of lotion or skin cream.

The Kennedy 1996 trial compared a zinc oxide cream (Baza) with a petrolatum ointment (Peri-Care) and a film-forming skin product (Cavilon No Sting Barrier Film) for the treatment of IAD. The first group received Baza three times per day, and as necessary during 12 days. The second group received Peri-Care three times a day, and as necessary. The third group received Cavilon No Sting Barrier Film with a swab applicator every 24,48 , or 72 hours.
The Wang 2011 study compared two commercial leave-on products, Dermlin and Genetime, for the treatment of IAD in the perianal environment. Dermlin was described as an advanced wound healing product. Genetime was described as a recombinant human epidermal growth factor.

This study was described as a short report in Chinese. Neither the intervention nor the outcomes were clear from the English translation; we found no contact details of the study author to ask for more information.

\section{Primary Outcomes}

Number of participants with incontinence-associated dermatitis (IAD) (residual, i.e. not healed)

In the Lewis-Byers 2002 trial $(n=31), 2 / 18(11.1 \%)$ of the participants cared for with Cavilon Antiseptic Skin Cleanser and Cavilon Durable Barrier Cream had IAD at the end of the trial period. Of the participants cared for with soap and water plus the lotion, $4 / 13(30.8 \%)$ had IAD at the end of the trial period. According to analysis in Review Manager 5 (RevMan 2014), this difference, in favour of Cavilon Antiseptic Skin Cleanser combined with Cavilon Durable Barrier Cream, was not significant (RR 0.36, 95\% Cl 0.08 to 1.68; very low quality evidence; Summary of findings for the main comparison; Analysis 1.1).

Intention-to-treat analysis of the results from the Buckley 2014 trial $(n=142)$ demonstrated that IAD did not heal in $66 / 73$ $(90.4 \%)$ participants from the Desitin group and $54 / 69(78,3 \%)$ participants from the Calmoseptine group. According to analysis in Review Manager 5 (RevMan 2014), this difference, in favour of Calmoseptine, was not significant (RR $1.16,95 \% \mathrm{Cl} 1.00$ to 1.34 ; moderate quality evidence; Summary of findings for the main comparison; Analysis 1.1).

\section{Number of participants with IAD (new) (only suitable to evaluate interventions for preventing IAD)}

During the Anthony 1987 trial $(n=57), 2 / 11(18.2 \%)$ participants from the standard zinc oxide group and 3/16 (18.8\%) participants from the Sudocrem group, who had no IAD at start of the study, developed IAD (RR 1.03, 95\% CI 0.20 to 5.19; low quality evidence; Summary of findings for the main comparison; Analysis 1.2).

The Brunner 2012 trial $(n=64)$ demonstrated that the number of participants who developed IAD did not differ significantly between the group cared for with Cavilon Skin Cleanser and Cavilon No Sting Barrier Film and the group washed with the Comfort Shield Perineal Care Washcloth Dimethicone 3\% (RR 0.83, 95\% Cl 0.35 to 1.95; low quality evidence; Summary of findings for the main comparison; Analysis 1.2). In the group cared for with Cavilon Skin Cleanser and Cavilon No Sting Barrier Film, 7/31 participants (22.6\%) developed IAD. In the group washed with the Comfort Shield Perineal Care Washcloth Dimethicone 3\%, 9/33 (27.3\%) participants developed IAD.

\section{Number of participants not satisfied with treatment}

Not reported.

\section{Secondary Outcomes}

Participants' observations

Not reported. 


\section{Quantification of symptoms (objective measures)}

One trial, the Buckley 2014 trial $(n=121)$, measured the change in surface affected by IAD in patients treated with Desitin $(n=65)$ and patients treated with Calmoseptine $(n=56)$. The change in surface area affected by IAD was significantly more reduced with the use of Calmoseptine $\left(P=0.001\right.$, MD $81.60 \mathrm{~cm}^{2}, 95 \% \mathrm{Cl} 36.87$ to 127.33 , Analysis 1.3).

\section{Clinicians' observations}

Not reported.

\section{Quality of life}

Not reported.

\section{Economic data}

Three trials reported on the cost of products (Baatenburg de Jong 2004; Brunner 2012; Kennedy 1996).

The Baatenburg de Jong 2004 trial $(n=39)$ suggested that the cost of trial products and application-related products (price year not reported) was on average highest for zinc oxide oil (EUR 14.16, standard deviation (SD) 1.83) versus Cavilon No Sting Barrier Film (EUR 7.55, SD 8.60). Nursing time spent was also on average higher for zinc oxide oil (208.95 minutes, SD 53.84) versus Cavilon No Sting Barrier Film (161.96 minutes, SD 55.55). As a consequence, the total costs were on average higher for zinc oxide oil (EUR 102.96, SD 23.25) versus Cavilon No Sting Barrier Film (EUR 76.13, SD 25.48). The difference between groups was not measured statistically and so we cannot be sure if differences in average costs are real or not. We could not analyse these economic data in Review Manager 5 (RevMan 2014), because the number of participants per group was not reported, and the study authors did not respond to our request for more details.

The Brunner 2012 trial $(n=64)$ reported that the product costs per trial day (price year not reported) were significantly higher for the combined use of Cavilon Skin Cleanser and Cavilon No Sting Barrier Film (USD 6.59, $\mathrm{n}=31$ ) compared to the use of Comfort Shield Perineal Care Washcloth Dimethicone 3\% (USD 2.67, $n=33$ ) (P= 0.006). Because no SDs or other statistics were reported, we were unable to undertake analysis in Review Manager 5 (RevMan 2014).

The Kennedy 1996 trial $(n=40)$ suggested that Peri-Care $(n=8)$ was on average less expensive than Baza $(n=8)$ in terms of daily cost of product use (Peri-Care USD 0.8 versus Baza USD 1.2) (price year 1995). Baza was less expensive than Cavilon No Sting Barrier Film if Cavilon No Sting Barrier Film was applied every $24(n=8)$ or 48 hours $(n=8$ ) (Baza USD 1.2 versus Cavilon No Sting Barrier Film USD 2.3 or USD 1.1). Baza was on average more expensive than Cavilon No Sting Barrier Film, if the latter was applied every 72 hours $(n=8)$ (Baza USD 1.2 versus Cavilon No Sting Barrier Film USD 0.8). Peri-Care was on average less expensive than Cavilon No Sting Barrier Film if the latter was applied every 24 or 48 hours (PeriCare USD 0.8 versus Cavilon No Sting Barrier Film USD 2.3 or USD 1.1). Peri-Care costs on average the same as Cavilon No Sting Barrier Film if the latter was applied every 72 hours (USD 0.8). No levels of significance were provided and as a consequence it is unclear whether any difference in average costs are real. Due to the limited reporting of statistical data, we were unable to perform analysis in Review Manager 5 (RevMan 2014). We found no recent contact details of the study authors to ask for more information.
One trial, the Lewis-Byers 2002 trial $(n=31)$, reported on staff time. Staff time was on average shorter for the combined use of Cavilon Antiseptic Skin Cleanser plus Cavilon Durable Barrier Cream than for the combined use of soap and water plus the lotion. In the first group $(n=18)$, staff time was 41 minutes per day for an average of seven incontinence episodes per day. The mean duration of cleansing was five minutes, and for the application of Cavilon Durable Barrier Cream, two minutes. In the second group ( $n=13$ ), staff time was 120 minutes per day for an average of eight incontinence episodes per day. The mean duration of cleansing was 13 minutes, and for the application of the lotion, two minutes. No levels of significance were provided and as a consequence it is unclear whether any difference in average staff time are real. It was not possible to undertake analysis in Review Manager 5 because SDs were not reported (RevMan 2014). The study authors did not respond on our request for more details.

One trial, the Baatenburg de Jong 2004 trial $(n=39)$, reported on incremental cost-effectiveness, reported as the incremental cost per 1 point improvement in skin condition. The incremental cost per 1 point improvement was EUR 98.06 for zinc oxide oil, and EUR 28.36 for Cavilon No Sting Barrier Film (price year not reported). No estimate of the imprecision around this estimate of incremental cost-effectiveness was reported. Following guidance from Campbell and Cochrane Economics Methods Group, it is not appropriate to consider meta-analysis of such data. Rather consideration should focus on what issues might determine such results.

\section{Adverse effects (of the interventions)}

The Buckley 2014 trial reported that no adverse effects occurred during the study while using Desitin and Calmoseptine.

Other outcomes (non-prespecified outcomes judged important when performing the review)

These outcomes were: IAD severity; number of participants with IAD completely healed, and number of participants with bacterial or fungal infection.

\section{IAD severity}

Four trials reported on IAD severity (Anthony 1987; Baatenburg de Jong 2004; Kennedy 1996; Lewis-Byers 2002).

The Anthony 1987 trial $(n=57)$ demonstrated a reduction in IAD severity in $92.3 \%$ of the participants from the Sudocrem group ( $\mathrm{n}$ $=29$ ) and $37.5 \%$ of the participants from the standard zinc oxide group $(n=28)$ after seven days. A reduction in IAD severity was identified in $84.6 \%$ of the participants from the Sudocrem group and $50.0 \%$ of the participants from the standard zinc oxide group after 14 days. The researchers mentioned a significantly greater improvement of IAD severity in favour of Sudocrem at both time points $(P<0.01)$. Because only percentages were provided, it was not possible to undertake an analysis in Review Manager 5 for the outcome 'IAD severity' (RevMan 2014). We found no recent contact details of the study authors to ask for more information.

The Baatenburg de Jong 2004 trial $(\mathrm{n}=39)$ demonstrated an improvement in IAD severity in participants treated with zinc oxide oil as in participants treated with Cavilon No Sting Barrier Film, with a significantly greater improvement in the group treated with Cavilon No Sting Barrier Film $(P=0.04)$. Because only a $P$ value was 
reported, it was not possible to undertake an analysis in Review Manager 5 (RevMan 2014).

The Kennedy 1996 trial $(n=40)$ demonstrated that the IAD severity improved significantly in participants treated with Peri-Care $(n=8)$, Baza $(n=8)$ or Cavilon No Sting Barrier Film $(n=24)$. No statistics were provided. None of the groups showed a significantly greater improvement in IAD severity than the other. Due to the limited reporting of statistical data, we were unable to perform analysis in Review Manager 5 (RevMan 2014). We found no recent contact details of the study authors to ask for more information.

The Lewis-Byers 2002 trial $(n=31)$ demonstrated that the severity of IAD did not significantly differ between the group cared for with Cavilon Antiseptic Skin Cleanser and Cavilon Durable Barrier Cream (mean score $0.28 / 4$, SD $0.83, \mathrm{n}=18$ ) and the group cared for with soap and water plus the lotion (mean score $0.77 / 4$, SD 1.30, $n=13$ ). The MD was $-0.49(95 \% \mathrm{Cl}-1.29$ to 0.31 ; Analysis 1.6$)$.

\section{Number of participants with IAD completely healed}

One trial, the Buckley 2014 trial $(n=142)$, reported on the number of participants with IAD completely healed during a follow-up period of six days. Based on the intention-to-treat analysis, 15/69 $(21.7 \%)$ participants from the Calmoseptine group and $7 / 73(9.6 \%)$ participants from the Desitin group completely healed during the study. According to analysis in Review Manager 5 (RevMan 2014), the difference, in favour of Calmoseptine, was not significant (RR $0.44,95 \% \mathrm{Cl} 0.19$ to 1.02 ; Analysis 1.5 ).

\section{Number of participants with bacterial or fungal infection}

One trial, the Buckley 2014 trial $(n=142)$, reported on the number of participants with fungal infections as a secondary outcome. During this trial, 4/142 (2.8\%) participants were withdrawn because of fungal infections in the IAD area.

\section{Any skin care procedure (method or frequency of application) versus any unstructured skin care procedure}

Two trials compared a skin care procedure (method or frequency of application) versus soap and water (Beeckman 2011; Schoonhoven 2015).

The Beeckman 2011 trial compared a structured skin care procedure using a washcloth with cleansing, moisturising, and skin protecting properties with the standard use of soap and water. The trial washcloth was the Comfort Shield Perineal Care Washcloth Dimethicone 3\%.

The intervention group was washed daily with the Comfort Shield Perineal Care Washcloth at routine perineal skin hygiene times, and after each diaper/pad change. No towel rubbing was allowed. In case of an extremely soiled skin, a soft washcloth and lukewarm water to remove soiling and a soft towel were used to dry the skin. The control group was washed with a soft washcloth, soap $(\mathrm{pH} 6.5$ to 7.5 ) and water at routine perineal skin hygiene times, and after each diaper/pad change.

The Schoonhoven 2015 trial compared the use of a washcloth impregnated with a lotion with soap and water for the prevention and treatment of skin abnormalities and skin lesions. The trial washcloths were the Wet Wash Gloves from Abena.
The intervention group was washed daily in bed with the Wet Wash Gloves which were heated in the microwave before use. No towel rubbing was allowed. The control group was washed daily using tap water and soap (different types), wash gloves, and towels.

The report of this trial provides results on skin abnormalities (e.g. erythema, erosions, discolorations of the wound bed) and significant skin lesions (non-intact skin). These results, however, were not specific for IAD, but included any kind of skin abnormalities and lesions over the whole body.

\section{Primary Outcomes}

Number of participants with incontinence-associated dermatitis (IAD) (residual, i.e. not healed)

The Beeckman 2011 trial $(n=141)$ demonstrated that, after 120 days, significantly fewer participants washed with the Comfort Shield Perineal Care Washcloth $(n=73)$ had IAD versus the group washed with soap and water $(n=68)$. After adjusting for clustering effect, $7.9 \%$ participants washed with the washcloth had IAD versus $25.9 \%$ of the participants washed with soap and water (RR 0.31, $95 \% \mathrm{Cl} 0.12$ to 0.79 ; moderate quality evidence; Summary of findings 2; Analysis 2.1).

Number of participants with IAD (new) (only suitable to evaluate interventions for preventing IAD)

Not reported.

\section{Number of participants not satisfied with treatment}

Not reported.

\section{Secondary Outcomes}

\section{Participants' observations}

Not reported.

\section{Quantification of symptoms (objective measures)}

Not reported.

\section{Clinicians' observations}

Not reported.

\section{Quality of life}

Not reported.

\section{Economic data}

Not reported.

\section{Adverse effects (of the interventions)}

The Schoonhoven 2015 trial reported the absence of any Suspected Unexpected Serious Adverse Reaction occurring while comparing the use of a washcloth impregnated with a lotion with soap and water.

\section{Other outcomes (non-prespecified outcomes judged important when performing the review)}

These outcomes were: IAD severity; number of participants with IAD completely healed, and number of participants with bacterial or fungal infection. 


\section{IAD severity}

One trial, the Beeckman 2011 trial $(n=141)$, reported on IAD severity. At the end of this trial, the IAD severity was significantly less in the group washed with the Comfort Shield Perineal Care Washcloth $(n=73)$ versus the group washed with soap and water ( $n$ $=68)(\mathrm{MD}-2.50,95 \% \mathrm{Cl}-3.19$ to -1.81 , Analysis 2.2).

Number of participants with IAD completely healed

Not reported.

Number of participants with bacterial or fungal infection

The Beeckman 2011 trial also reported on the number of participants developing any bacterial or fungal infection. During this trial, no participants developed any bacterial or fungal infection.

3. Any method of application of a topical skin care product versus another method of application of the topical skin care product

No suitable trials were found.

\section{Any frequency of application of a topical skin care product versus another frequency of application of the topical skin care product}

Two trials compared different frequencies of application of topical skin care products (Conley 2014; Kennedy 1996)

The Conley 2014 trial tested a structured skin care procedure, including the application of a skin cleanser and a leave-on product, for the prevention and treatment of IAD. The skin cleanser and the leave-on product were applied every six hours or every 12 hours. The skin care procedure consisted of gentle cleansing of the skin with the skin cleanser containing Aloe vera mixed with water and a cleansing lotion followed by patting the skin dry. If no erythema was observed, a leave-on product with silicone was applied. If erythema was present, a leave-on product with zinc oxide and menthol was applied.

The Kennedy 1996 trial compared three frequencies of the application of a film-forming skin product (Cavilon No Sting Barrier Film: every 24,48 , or 72 hours.

\section{Primary Outcomes}

Number of participants with incontinence-associated dermatitis (IAD) (residual, i.e. not healed)

The Conley 2014 trial $(n=99)$ identified no significant difference in the number of participants with IAD when performing the skin care procedure every six hours (56.4\%) versus every 12 hours $(60.0 \%)$ $(P=0.718)$. We were unable to perform any analysis in Review Manager 5 because the study authors only provided percentages for the outcome of interest and no statistics on missing data (RevMan 2014). The study authors did not reply to our request for more details.

Number of participants with IAD (new) (only suitable to evaluate interventions for preventing IAD)

Not reported.

\section{Number of participants not satisfied with treatment}

Not reported.

\section{Secondary Outcomes}

\section{Participants' observations}

Not reported.

\section{Quantification of symptoms (objective measures)}

Not reported.

\section{Clinicians' observations}

Not reported.

\section{Quality of life}

Not reported

\section{Economic data}

One trial, the Kennedy 1996 trial $(n=40)$, reported on the cost of products (Price year 1995). This trial demonstrated that the application of Cavilon No Sting Barrier Film every 72 hours $(n=8)$ was the least expensive (USD 0.8), followed by the application every 48 hours $(\mathrm{n}=8)$ (USD 1.1) and the application every 24 hours ( $\mathrm{n}$ = 8) (USD 2.3). Because no SDs were reported, we were unable to undertake an analysis in Review Manager 5 (RevMan 2014).

\section{Adverse effects (of the interventions)}

Not reported.

\section{Other outcomes (non-prespecified outcomes judged important when performing the review)}

These outcomes were: IAD severity; number of participants with IAD completely healed, and number of participants with bacterial or fungal infection.

\section{IAD severity}

One trial, the Kennedy 1996 trial $(n=40)$, reported on the IAD severity. This trial demonstrated that the IAD severity improved significantly in participants treated with Cavilon No Sting Barrier Film every 24 hours $(n=8)$, every 48 hours $(n=8)$ or every 72 hours $(n=8)$. No statistics were mentioned. None of the groups showed a significantly greater improvement in IAD severity than the other. Due to the limited reporting of statistical data, we were unable to perform any analysis in Review Manager 5 (RevMan 2014). We found no recent contact details of the study authors to ask for more information.

\section{Number of participants with IAD completely healed}

Not reported.

Number of participants with bacterial or fungal infection Not reported.

\section{DISCUSSION}

The aim of this review was to assess and compare the effectiveness of various products and procedures to prevent and treat incontinence-associated dermatitis (IAD) in adults. In this context, the review focused on topical skin care products, 
structured skin care procedures, application methods for topical skin care products, and frequency of application of topical skin care products.

\section{Summary of main results}

\section{Primary outcomes}

Four trials assessed the effectiveness of topical skin care products (skin cleansers and leave-on products) against the outcome 'number of participants with IAD (residual/new)' (Brunner 2012; Buckley 2014; Cooper 2001; Lewis-Byers 2002). Two of these trials (Brunner 2012; Lewis-Byers 2002) tested a combined use of skin care products in each trial group (for example, a skin cleanser and a leave-on product). One trial compared the use of a skin cleanser with soap and water (Cooper 2001). Another trial assessed whether a structured skin care procedure could reduce the same outcome (as above) in comparison with soap and water (Beeckman 2011).

Based on the included trials, we found low quality evidence for the effectiveness of a skin cleanser (Clinisan) compared with soap and water. We found evidence of moderate quality for the effectiveness of a structured skin care procedure (using a washcloth with cleansing, moisturising, and protecting properties; Comfort Shield Perineal Care Washcloth Dimethicone 3\%) compared with soap and water. No differences were found between topical skin care products (skin cleansers and leave-on products) in reducing the number of participants with IAD. However, it should be noticed that the sample size of the latter trials was rather small $(<100$ participants), except for the Buckley 2014 trial $(n=142)$.

\section{Secondary outcomes}

One trial assessed the outcomes 'size of the skin lesion' (surface affected by $I A D$ ) and 'number of participants completely healed' (Buckley 2014). The researchers compared two different zinc oxide based leave-on products (Desitin and Calmoseptine) and identified a significant difference in favour of Calmoseptine for both outcomes. However, the two products differed in the amount of zinc oxide being applied (20\% in Calmoseptine, $40 \%$ in Desitin) and the presence of other active ingredients (such as menthol in Calmoseptine and lanolin, petrolatum, and cod liver oil in Desitin). Consequently, it is not clear which amount of zinc oxide is optimal or which ingredients are pivotal for the treatment of IAD.

Low quality evidence was found for economic data ('cost of product', 'staff time', 'incremental cost-effectiveness'), based on a few small studies.

Two trials compared the costs for daily use of various leave-on products (zinc oxide based products, petrolatum ointment) with those of a film-forming skin product (also a leave-on product) (Baatenburg de Jong 2004; Kennedy 1996). The methods used for economic analysis varied across these trials. It should also be mentioned that the zinc oxide products and the petrolatum ointment were applied more frequently than the film-forming skin product (at least twice daily versus every 24,48 , or 72 hours). The findings from the Kennedy 1996 study, which seem to be outdated, indicated that the film-forming skin product Cavilon No Sting Barrier Film was more expensive on average if applied on a daily base. However, if this film-forming skin product could be applied every 72 hours, then it would be less expensive on average than the zinc oxide cream, Baza and the petrolatum ointment, Peri-Care (Kennedy 1996). Furthermore, if the costs for application- related products (gloves, spatula, gauze) were included, then the film-forming skin product mentioned above, applied according to participants' needs, would be less expensive on average than the zinc oxide oil (Baatenburg de Jong 2004). The lack of statistical comparison hover means that no conclusion can be drawn about differences in cost.

One trial reported that the cost for the daily use of a washcloth with cleansing, moisturising and protecting properties (Comfort Shield Perineal Care Washcloth Dimethicone 3\%) was significantly lower than the use of two separate leave-on products (Cavilon Skin Cleanser and Cavilon No Sting Barrier Film) (Brunner 2012).

Staff time was assessed in two small trials comparing soap and water with a skin cleanser (Byers 1995; Lewis-Byers 2002). The findings from both trials indicated that staff time can be reduced when using a no-rinse skin cleanser (including Triple Care Cleanser and Cavilon Antiseptic Skin Cleanser). This could be expected as washing with a no-rinse skin cleanser does not need the filling and emptying of a water basin and the drying of the participant with a towel. However, no statistical comparisons were reported and conclusions remain tentative.

The incremental cost-effectiveness was calculated for the comparison of zinc oxide oil with a film-forming skin protectant (Baatenburg de Jong 2004). When using the film-forming skin protectant Cavilon No Sting Barrier Film, the application frequency, application-related product costs and staff time were on average lower than when using zinc oxide oil. In addition, IAD severity was also significantly lower. No estimate of the imprecision around this estimate was provided and no guidance was provided as to how interpret the incremental cost-effectiveness result. The trial team however concluded that the total costs (for products and staff time) per point improvement in IAD severity were in favour of the filmforming skin protectant Cavilon No Sting Barrier Film compared with zinc oxide oil.

Three trials reported results on the outcome 'IAD severity' when comparing various leave-on products (zinc oxide products, petrolatum ointment, film-forming skin protectant). In one small trial $(n=34)$, IAD severity improved more when using the filmforming skin protectant Cavilon No Sting Barrier Film compared with zinc oxide oil (Baatenburg de Jong 2004). However, another similar trial, found no significant difference comparing the same film-forming skin protectant with the zinc oxide cream, Baza (Kennedy 1996). The latter trial included only 16 participants. A last trial found more improvement in terms of reduced skin redness when using Sudocrem compared to a standard zinc oxide cream (Anthony 1987). Because of other differences in composition of these two products (such as amount of zinc oxide applied), it was not clear whether the ingredients responsible for the antiseptic properties of Sudocrem determined the outcome. As described above, the trials of Anthony 1987, Baatenburg de Jong 2004 and Kennedy 1996 compared different leave-on products with each other. The overall findings of these trials suggested that IAD severity improved for all leave-on products.

One trial analysed the improvement in IAD severity when comparing a structured skin care procedure (washcloth with cleansing, moisturising, and protecting properties) with soap and water (Beeckman 2011). In this trial, only residents washed with the washcloth (Comfort Shield Perineal Care Washcloth Dimethicone $3 \%)$ showed a significant improvement in IAD severity. 


\section{Overall completeness and applicability of evidence}

This review included 13 (quasi-)RCTs in a qualitative synthesis. The trials provided data for only two of the three proposed primary outcomes ('number of participants with IAD residual (i.e. not healed)' and 'number of participants with IAD (new)') and three of the seven proposed secondary outcomes ('quantification of symptoms', 'economic data' and 'other outcomes'). We did not find data on four of seven participant-important outcomes: 'number of participants not satisfied with treatment', 'number of participants with pain due to IAD', 'number of participants with pain due to skin care products or procedure' and 'adverse reaction due to skin care product or procedure'.

Although we included only 13 trials, this review contains results on a wide range of topical skin care products $(n=15)$ and procedures $(n=3)$. We studied the three subgroups of topical skin care products (see Types of interventions): no-rinse skin cleansers, moisturisers, and skin protectants, either as separate products or combined into one product. We also studies structured skin care procedures. Nevertheless, the variation in products and procedures did not allow us to pool data.

Almost half of the trials $(n=6)$ included participants with IAD as well as without IAD at the start of the trial. We did not perform a subgroup analysis. Consequently, we could not identify if the tested skin care products and procedures performed as well in the prevention as the treatment of IAD.

We found two ongoing studies (see Characteristics of ongoing studies). The NCT02570139 2015 trial compares the use of two film forming skin protectants, Cavilon Advanced High Endurance Skin Protectant and ConvaTec Sensi-Care Protective Barrier ( $\mathrm{n}=$ 102). The outcomes measured in this trial are IAD severity, IAD healing, pain due to IAD, and prevention of IAD development. The NCT02690753 2016 trial compares a washcloth with cleansing, moisturising and skin protecting properties (Comfort Shield Barrier Cream Cloths) with standard care $(n=226)$. The outcomes measured include number of participants with IAD (new), and comfort and tolerance of the participants. The reports of these studies will be analysed for the next update of this review.

\section{Quality of the evidence}

A quantitative meta-analysis was not appropriate. We were unable to pool the results from the different trials due to heterogeneity in participant population, skin care products, skin care procedure, outcomes, and measurement tools.

Almost all trials showed at least two sources of bias. Selective reporting of trial results was a less common source of bias and was present in four trials (Anthony 1987; Brunner 2012; Dieter 2006; Kennedy 1996), and unclear in one trial (Wang 2011). Lack of blinding was the most common source of bias. Blinding of participants and personnel was not possible in all but one trial due to visual differences in the skin care products (Anthony 1987). In only two trials (Cooper 2001; Buckley 2014), the outcome assessors were blinded by using photographs. Another possible source of bias was funding. At least five trials were funded by industry (Baatenburg de Jong 2004; Buckley 2014; Byers 1995; Cooper 2001; Kennedy 1996). The overall risk of bias in the included studies was high.
We could only perform a GRADE assessment of the quality of evidence for two of the primary outcomes of this review, 'number of participants with IAD (new)' and 'number of participants with IAD (residual, i.e. not healed)'; with six single studies. This was due to a lack of statistical data (standard deviations, frequencies) necessary to calculate risk ratios or mean differences. The results from the GRADE assessment showed low to very low quality of evidence for four trials, based on the risk of bias described above (Anthony 1987; Brunner 2012; Cooper 2001; Lewis-Byers 2002). Furthermore, the imprecision of the point estimates was serious (large confidence intervals) as a consequence of small sample sizes. Only the Beeckman 2011, and the Buckley 2014 studies showed moderate quality evidence. The Beeckman 2011 trial was the only trial which proved (post hoc) an adequate sample size to detect real differences (statistical power).

As a conclusion, the quality of evidence for the prevention and management of IAD was very low to moderate. All data should be interpreted with caution.

\section{Potential biases in the review process}

We performed a rigorous literature search to prevent missing relevant trials. We searched the Cochrane Incontinence Group Specialised Trial Register, major databases, reference lists, and conference proceedings. In addition, we contacted specialists in the field and all authors of the included studies. Furthermore, all review authors are experts in the field, and performed multiple literature reviews on healthcare subjects, and more specifically on the prevention and treatment of IAD in adults. Finally, we only identified three supplementary trials via reference lists. As a consequence, we believe the possibility of missing any relevant trial was low.

The Cochrane Review protocol was written out and followed in detail. All steps in the review process were performed by at least two (independently working) researchers. In addition, the interpretation of the findings was done by all review authors, working in different countries around the globe. This minimised the risk for errors, inaccuracies, and influences of individual interest. Furthermore, experience was brought together.

The strict inclusion criteria limited the number of studies available for inclusion. Many trials were not performed in adults, not randomised, did not test topical skin care products or did not meet the proposed outcomes. Whilst the inclusion criteria limited the list of included studies, the studies with the strongest set-up were used to draw conclusions.

\section{Agreements and disagreements with other studies or reviews}

This review confirms the conclusions of two other systematic reviews. Beeckman 2009 identified limited evidence for the effectiveness of various interventions for the prevention and treatment of IAD in adults. Furthermore, as in our Cochrane Review, soap and water performed poorly in the prevention and treatment of IAD. Similarly, the Corcoran 2013 study, which focused on trials testing skin protectants, could not recommend any skin protectant over another due to a lack of evidence. Both reviews identified the same weaknesses in trial design: absence of power calculations in advance, small sample sizes, no blinded assessments, and short trial periods. Based on the findings of our review and the 
Beeckman 2011 and Corcoran 2013 reviews, it is clear that the available evidence on topical skin care products and procedures for prevention and management of IAD in adults is limited. More research to draw conclusions needs to be done.

The trials included in our review studied various topical skin care products (skin cleansers and leave-on products) for the prevention and treatment of IAD. Some commercial leave-on products seem to perform better than others, but we could not identify which ingredients were responsible for this difference in effectiveness. Recently Kottner and Beeckman published an overview of knowledge and recommendations concerning IAD and pressure ulcers in geriatric patients (Kottner 2015). These authors combined research findings with expert opinion. Kottner and Beeckman agreed with the existence of various skin care products concerning IAD and the lack of evidence on differences in benefits between products. In addition, they described that the performance of leave-on products not only depends on individual ingredients but especially on the combination of ingredients and the overall formulation. Furthermore, in accordance with our finding that most trials made no explicit distinction between the prevention and treatment of IAD, Kottner and Beeckman described the absence of a technology to promote skin barrier recovery after maceration in the elderly (Kottner 2015).

\section{AUTHORS' CONCLUSIONS}

\section{Implications for practice}

There is little evidence, of very low to moderate quality, on the effectiveness of interventions for preventing and treating incontinence-associated dermatitis (IAD) in adults. Consequently, it's not clear whether any leave-on product (moisturiser, skin protectant, single or combined) performs better than another. Using a leave-on product and avoiding soap is better than using nothing. The performance of leave-on products depends on the combination of ingredients, the overall formulation and the usage (e.g. amount applied).

\section{Implications for research}

The current literature on interventions for preventing and treating IAD in adults consists of a few small trials of low to, at most, moderate quality. None of the trials identified were comparable in terms of trial set-up. In addition, the functioning of the tested leaveon products was unclear (moisturising, skin protecting, or both). Furthermore, we found no data on several participant-important outcomes.

Future trials should try to overcome the methodological weaknesses identified through this review. First of all, we recommend the use of sample sizes large enough to reflect possible differences in effectiveness of interventions. A priori sample size calculation is mandatory. In addition, we recommend more efforts to blind the outcome assessment and to use valid methods for randomisation of participants and allocation concealment.

Researchers must report the results of their trials accurately and according to CONSORT 2010. We identified a lack of reporting of standard deviations, absolute frequencies, and levels of significance ( $P$ values). These data are essential to adequately interpret the research results and to compare outcomes across trials (e.g. in a meta-analysis). Another consideration is the time of follow-up. For interventions aimed at preventing IAD, we recommend a follow-up period of at least six weeks, based on the time to develop IAD which is between one and 42 days (Bliss 2011). For interventions aimed at treating IAD, we recommend a follow-up period of at least three weeks, based on the time to IAD-healing which is between one and 19 days (Bliss 2011). High quality confirmatory studies will enhance valuable conclusions about the effectiveness of products and procedures to prevent and treat IAD. We further recommend using standardised and comparable prevention and/or treatment regimens in different settings/regions.

While performing our review, we determined that the function of the skin care products (moisturising versus skin protecting) was not always clear. To enhance the interpretation and comprehensibility of the results of our Cochrane Review, we classified all products not being a skin cleanser as leave-on products. The latter group consisted of moisturisers and skin protectants, either as a separate product or combined into one product. To enhance correct product selection and comparability in practice and research, we highly recommend the use of a standardised language and terminology in the description of skin care products.

There is a need for uniform, relevant, and participant-important outcomes. Patients should be involved in the selection of these outcomes, to enhance the contribution of trial results in informed decision-making. Based on our experience with this Cochrane Review, we recommend the development of a core set of outcomes. This may improve the comparability of outcomes across studies. More comparability is important to be able to pool results. Recently the IAD International Research Group has launched a project which aims to develop a core outcome set of well-defined IADrelated outcomes for clinical IAD research. This outcome set will also include validated tools for outcome measurement (Beeckman 2015a).

\section{ACKNOWLEDGEMENTS}

We would like to acknowledge Sheila Wallace for her contribution in the electronic searches and for her support during the performance of this Cochrane Review. We would also like to thank the following Cochrane Incontinence editorial base staff members for their help and support with this review: Lyn Ajanaku, Jonathan Cook, Suzanne Macdonald, Catherine Murphy, Muhammad Imran Omar, Luke Vale, and Kate Williams. 


\section{R E F E R E N C E S}

\section{References to studies included in this review}

Anthony 1987 \{published data only\}

Anthony D, Barnes E, Malone-Lee J, Pluck R. A clinical study of Sudocrem in the management of dermatitis due to the physical stress of incontinence in a geriatric population. Journal of Advanced Nursing 1987;12(5):599-603. [sr-incont519]

\section{Baatenburg de Jong 2004 \{published data only\}}

Baatenburg de Jong $\mathrm{H}$, Admiraal $\mathrm{H}$. Comparing cost per use of $3 \mathrm{M}$ Cavilon No Sting Barrier Film with zinc oxide oil in incontinent patients. Journal of Wound Care 2004;13(9):398-400. [sr-incont19444]

\section{Beeckman 2011 \{published data only\}}

Beeckman D, Verhaeghe S, Defloor T, Schoonhoven L, Vanderwee K. A 3-in-1 perineal care washcloth impregnated with dimethicone $3 \%$ versus water and $\mathrm{pH}$ neutral soap to prevent and treat incontinence-associated dermatitis: a randomized, controlled clinical trial. Journal of Wound, Ostomy, and Continence Nursing 2011;38(6):627-34. [sr-incont42976]

\section{Brunner 2012 \{published data only\}}

Brunner M, Droegemueller C, Rivers S, Deuser WE. Prevention of incontinence-related skin breakdown for acute and critical care patients: comparison of two products. Urologic Nursing 2012;32(4):214-9. [sr-incont45816]

\section{Buckley 2014 \{published data only\}}

Buckley B, Dofitas R, Baltazar W, Quiambao P, Razor B. Topical zinc oxide based creams in a structured care regimen for the treatment of incontinence associated dermatitis in hospitalized adults and older children: A randomized, controlled trial (Abstract number 321). Neurourology and Urodynamics 2014;33(6):760-1. [sr-incont64413]

* Razor B, Buckley B, Quiambao P, Dofitas R, Baltazar W. Incontinence-associated dermatitis (IAD) study: Blinded assessment and treatment with zinc oxide-based ointment. World Council of Enterostomal Therapists Journal 2014;34(4):13-23.

\section{Byers 1995 \{published data only\}}

Byers PH, Ryan PA, Regan MB, Shields A, Carta SG. Effects of incontinence care cleansing regimens on skin integrity. Journal of Wound, Ostomy, and Continence Nursing 1995;22(4):187-92. [sr-incont2967]

\section{Conley 2014 \{published data only\}}

Conley P, McKinsey D, Ross O, Ramsey A, Feeback J. Does skin care frequency affect the severity of incontinence-associated dermatitis in critically ill patients?. Nursing 2014;44(12):27-32. [sr-incont64906]

\section{Cooper 2001 \{published data only\}}

Cooper P, Gray D. Comparison of two skin care regimes for incontinence. British Journal of Nursing 2001;10(6 Suppl):S6S10. [sr-incont14649]
Dieter 2006 \{published data only\}

Dieter L, Drolshagen C, Blum K. Cost-effective, quality care for the patient with incontinence. Thirty-eigth Annual Meeting of Wound Ostomy and Continence Nurse Society; 2006 June 24-28; Minneapolis. Minneapolis (MN): Wound Ostomy and Continence Nurse Society, 2006. [sr-incont27316]

\section{Kennedy 1996 \{published data only\}}

Kennedy KL, Lutz J. Comparison of the efficacy and costeffectiveness of three skin protectants in the management of incontinence dermatitis. 1996 European Conference on Advances in Wound Management; 1996 Oct 4; Amsterdam. Amsterdam, 1996. [sr-incont67959]

Lewis-Byers 2002 \{published data only\}

Lewis-Byers K, Thayer D. An evaluation of two incontinence skin care protocols in a long-term care setting. Ostomy Wound Management 2002;48(12):44-51. [sr-incont15851]

\section{Schoonhoven 2015 \{published data only\}}

Schoonhoven L, van Gaal BG, Teerenstra S, Adang E, van der Vleuten C, van Achterberg T. Cost-consequence analysis of "washing without water" for nursing home residents: a cluster randomized trial. International Journal of Nursing Studies 2015;52(1):112-20.

\section{Wang 2011 \{published data only\}}

Wang Y, Zhu X, Zhou M. Comparative observation of Dermlin and Genetime used for fecal incontinence patients with perianal skin damage. Chinese Nursing Research 2011;25(3C):776-7. [srincont42528]

\section{References to studies excluded from this review}

\section{Al-Samarrai 2007 \{published data only\}}

Al-Samarrai NR, Uman GC, Al-Samarrai T, Alessi CA. Introducing a new incontinence management system for nursing home residents. Journal of the American Medical Directors Association 2007;8(4):253-61.

\section{Bates-Jensen 2003 \{published data only\}}

Bates-Jensen BM, Alessi CA, Al Samarrai NR, Schnelle JF. The effects of an exercise and incontinence intervention on skin health outcomes in nursing home residents. Journal of the American Geriatrics Society 2003;51(3):348-55.

\section{Bauer 2007 \{published data only\}}

Bauer C, Galvin EA, Kurosky A, DiBiase RJ, Miller S. Testing the efficacy of two products for the prevention of perineal dermatitis in immune compromised patients: a randomized clinical trial. Oncology Nursing Forum 2007;34(1):218. [srincont67957]

\section{Bennett 1998 \{published data only\}}

Bennett RG, Baran PJ, DeVone LV, Bacetti H, Kristo B, Tayback M, et al. Low airloss hydrotherapy versus standard care for incontinent hospitalized patients. Journal of the American Geriatrics Society 1998;46(5):569-76. 
Bliss 2007 \{published data only\}

Bliss DZ, Zehrer C, Savik K, Smith G, Hedblom E. An economic evaluation of four skin damage prevention regimens in nursing home residents with incontinence: economics of skin damage prevention. Journal of Wound, Ostomy, and Continence Nursing 2007;34(2):143-52.

\section{Brown 1994 \{published data only\}}

Brown DS. Diapers and underpads, part 1: skin integrity outcomes. Ostomy Wound Management 1994;40(9):20-8.

\section{Dealey 1995 \{published data only\}}

Dealey C. Pressure sores and incontinence: a study evaluating the use of topical agents in skin care. Journal of Wound Care 1995;4(3):103-5.

\section{Denat 2011 \{published data only\}}

Denat $\mathrm{Y}$, Khorshid L. The effect of 2 different care products on incontinence-associated dermatitis in patients with fecal incontinence. Journal of Wound, Ostomy, and Continence Nursing 2011;38(2):171-6.

\section{Fader 2003 \{published data only\}}

Fader M, Clarke-O'Neill S, Cook D, Dean G, Brooks R, Cottenden $\mathrm{A}$, et al. Management of night-time urinary incontinence in residential settings for older people: an investigation into the effects of different pad changing regimes on skin health. Journal of Clinical Nursing 2003;12(3):374-86.

\section{Harries 2016 \{published data only\}}

Harries FJ, Begg PA. Non-rinse skin cleansers: the way forward in preventing incontinence related moisture lesions?. Journal of Wound Care 2016;25(5):268-76.

\section{Holroyd 2014 \{published data only\}}

Holroyd S, Graham K. Prevention and management of incontinence-associated dermatitis using a barrier cream. British Journal of Community Nursing. Suppl Wound Care 2014;Suppl 12:S32-8.

\section{Iraji 2003 \{published data only\}}

Iraji F, Rezazadeh M. The efficacy of topical sucralfate in comparison with hydrocortizone cream in the treatment of diaper dermatitis: a randomized, double blind clinical trial. Iranian Journal of Dermatology 2003;3(6):8-12.

\section{James 1975 \{published data only\}}

James WS. A new use for an old ointment: Lantiseptic ointment as a treatment for diaper dermatitis. Journal of the Medical Association of Georgia 1975;64(5):132-3.

\section{Kyung 2014 \{published data only\}}

Kyung HP, Keum SK. Effect of a structured skin care regimen on patients with fecal incontinence. Journal of Wound, Ostomy, and Continence Nursing 2014;41(2):161-7.

\section{Leiby 1994 \{published data only\}}

Leiby DM, Shanahan N. Clinical study: assessing the performance and skin environments of two reusable underpads. Ostomy Wound Management 1994;40(8):30-7.

\section{Lyder 1992 \{published data only\}}

Lyder CH, Clemes-Lowrance C, Davis A, Sullivan L, Zucker A. Structured skin care regimen to prevent perineal dermatitis in the elderly. Journal of ET Nursing 1992;19(1):12-6.

\section{NCT02475512 2015 \{published data only\}}

NCT02475512, Beeckman D. A total body wash wipe combined with a genital wipe versus standard care (water and $\mathrm{pH}$ neutral soap) for washing of incontinent residents in a long-term care setting: a multicenter prospective randomised controlled clinical trial and health economical analysis in nursing homes. https://clinicaltrials.gov/show/NCT02475512 2015.

Netta-Turner 2008 \{published data only\}

Netta-Turner D, Bucher L, Dixon L, Layton NJ. Riding the research roller coaster: what went right, what went wrong?. Journal of Wound, Ostomy, and Continence Nursing 2008;35(5):469-75.

\section{Pinedo 2012 \{published data only\}}

Pinedo G, Zarate AJ, Inostroza G, Meneses X, Falloux E, Molina $\mathrm{O}$, et al. New treatment for faecal incontinence using zinc-aluminium ointment: a double-blind randomized trial. Colorectal Disease 2012;14(5):596-8.

Pittman 2012 \{published data only\}

Pittman J, Beeson T, Terry C, Kessler W, Kirk L. Methods of bowel management in critical care: a randomized controlled trial. Journal of Wound, Ostomy, and Continence Nursing 2012;39(6):633-9.

\section{Shin 2012 \{published data only\}}

Shin YS, Kim HJ, Moon NK, Ahn YH, Kim KO. The effects of uncoated paper on skin moisture and transepidermal water loss in bedridden patients. Journal of Clinical Nursing 2012;21(17-18):2469-76.

\section{Su 2015 \{published data only\}}

Su MY, Lin SQ, Zhou YW, Liu SY, Lin A, Lin XR. A prospective, randomized, controlled study of a suspension positioning system used with elderly bedridden patients with neurogenic fecal incontinence. Ostomy Wound Management 2015;61(1):30-9.

\section{Sugama 2012 \{published data only\}}

Sugama J, Sanada H, Shigeta Y, Nakagami G, Konya C. Efficacy of an improved absorbent pad on incontinence-associated dermatitis in older women: cluster randomized controlled trial. BMC Geriatrics 2012;12:22.

\section{Zehrer 2004 \{published data only\}}

Zehrer CL, Lutz JB, Hedblom EC, Ding L. A comparison of cost and efficacy of three incontinence skin barrier products. Ostomy Wound Management 2004;50(12):51-8.

\section{References to studies awaiting assessment}

Kajii 2005 \{published data only\}

Kajii F, Uchida E, Kamei T, Tanaka J, Kushiro W. Development of a preventive skin care protocol using a skin protection cleaning 
foam for frail elderly who had urinary and fecal incontinence. Bulletin of St. Luke's College of Nursing 2005;31:26-35.

\section{References to ongoing studies}

NCT02570139 2015 \{published data only\}

NCT02570139. Multi-center, randomized trial comparing the efficacy of $3 \mathrm{M}^{\mathrm{TM}}$ Cavilon ${ }^{\mathrm{TM}}$ Advanced Barrier Film for the treatment of incontinence-associated dermatitis to a commercially available moisture barrier. https:// clinicaltrials.gov/show/NCT02570139 (accessed 29 September 2016) 2015.

\section{NCT02690753 2016 \{published data only\}}

NCT02690753. A turn and positioning system and standardized incontinence care combined with tailored repositioning versus a standard repositioning protocol for pressure ulcer prevention: a multicenter prospective randomized controlled clinical trial and health economical analysis in a hospital setting. https:// clinicaltrials.gov/show/NCT02690753 (accessed 29 September 2016) 2016.

\section{Additional references}

\section{Ananthapadmanabhan 2004}

Ananthapadmanabhan K, Moore D, Subramanyan K, Misra M, Meyer F. Cleansing without compromise: the impact of cleansers on the skin barrier and the technology of mild cleansing. Dermatology and Therapy 2004;17:16-25.

\section{Beeckman 2007}

Beeckman D, Schoonhoven L, Fletcher J, Furtado K, Gunningberg L, Heyman H, et al. EPUAP classification system for pressure ulcers: European Reliability Study. Journal of Advanced Nursing 2007;60(5):682-91.

\section{Beeckman 2009}

Beeckman D, Schoonhoven L, Verhaeghe S, Heyneman A, Defloor T. Prevention and treatment of incontinence-associated dermatitis: Literature review. Journal of Advanced Nursing 2009;65(6):1141-54.

\section{Beeckman 2010}

Beeckman D, Schoonhoven L, Fletcher J, Furtado K, Heyman H, Paquay L. Pressure ulcers and incontinence-associated dermatitis: Effectiveness of the pressure ulcer classification education tool on classification by nurses. Quality and Safety in Health Care 2010;19(5):e3.

\section{Beeckman 2014}

Beeckman D, Van Lancker A, Van Hecke A, Verhaeghe S. A systematic review and meta-analysis of incontinenceassociated dermatitis, incontinence, and moisture as risk factors for pressure ulcer development. Nursing in Research \& Health 2014;37(3):204-18.

\section{Beeckman 2015a}

Beeckman D, Kottner J, IAD International Research Group. Developing a core outcome set for incontinence-associated dermatitis (IAD) research. www.comet-initiative.org/studies/ details/383 (accessed 8 February 2016).

\section{Bliss 2011}

Bliss D, Savik K, Thorson M, Ehman S, Lebak K, Beilman G. Incontinence-associated dermatitis in critically ill adults: time to development, severity, and risk factors. Journal of Wound, Ostomy, and Continence Nursing 2011;38(4):433-45.

\section{CONSORT 2010}

Schulz KF, Altman DG, Moher D, the CONSORT Group. CONSORT 2010 Statement: updated guidelines for reporting parallel group randomised trials. www.consort-statement.org/consort-2010 (accessed 8 February 2016).

\section{Corcoran 2013}

Corcoran E, Woodward S. Incontinence-associated dermatitis in the elderly: treatment options. British Journal of Nursing 2013;22(8):450-7.

\section{Du Moulin 2008}

Du Moulin MF, Hamers JP, Ambergen AW, Janssen MA, Halfens RJ. Prevalence of urinary incontinence among community-dwelling adults receiving home care. Research in Nursing \& Health 2008;31(6):604-12.

\section{GRADEpro GDT 2014 [Computer program]}

GRADE Working Group, McMaster University. GRADEpro GDT. Hamilton (ON): GRADE Working Group, McMaster University, (Accessed 13 April 2016).

\section{Gray 2002}

Gray M, Ratliff C, Donovan A. Perineal skin care for the incontinent patient. Advances in Skin \& Wound Care 2002;15(4):170-8.

\section{Gray 2007}

Gray M, Bliss DZ, Doughty DB, Ermer-Seltun J, KennedyEvans KL, Palmer MH. Incontinence-associated dermatitis: a consensus. Journal of Wound, Ostomy, and Continence Nursing 2007;34(1):45-54.

\section{Gray 2010}

Gray M. Optimal management of Incontinence-associated dermatitis in the elderly. American Journal of Clinical Dermatology 2010;11(3):201-10.

\section{Gray 2012}

Gray M, Beeckman D, Bliss DZ, Fader M, Logan S, Junkin J, et al. Incontinence-associated dermatitis: a comprehensive review and update. Journal of Wound, Ostomy, and Continence Nursing 2012;39(1):61-74.

\section{Guyatt 2011}

Guyatt GH, Oxman AD, Kunz R, Atkins D, Brozek J, Vist G, et al. GRADE guidelines: 2. Framing the question and deciding on important outcomes. Journal of Clinical Epidemiology 2011;64(4):395-400. 


\section{Higgins 2011}

Higgins JP, Green S, editor(s). Cochrane Handbook for Systematic Reviews of Interventions Version 5.1.0 (updated March 2011). The Cochrane Collaboration, 2011. Available from handbook.cochrane.org.

\section{ISC 2009}

International Scientific Committee. Recommendations of the International Scientific Committee. Incontinence: evaluation and treatment of urinary incontinence, pelvic organ prolapse and faecal incontinence. Fourth International Consultation on Incontinence; 2008 July 5-9; Paris. Plymouth, UK: Health Publication Ltd, 2009.

\section{Junkin 2007}

Junkin J, Selekof J. Prevalence of incontinence and associated skin Injury in the acute care Inpatient. Journal of Wound, Ostomy, and Continence Nursing 2007;34(3):260-9.

\section{Kottner 2014}

Kottner J, Blume-Peytavi U, Lohrmann C, Halfens R. Associations between individual characteristics and incontinence-associated dermatitis: a secondary data analysis of a multicentre prevalence study. International Journal of Nursing Studies 2014 Feb 23 [epub ahead of print]. [DOI: 10.1016/j.ijnurstu.2014.02.012]

\section{Kottner 2015}

Kottner J, Beeckman D. Incontinence-associated dermatitis and pressure ulcers in geriatric patients. Giornale Italiano di Dermatologia e Venereologia 2015;150(6):717-29.

\section{Langemo 2011}

Langemo D, Hanson D, Hunter S, Thompson P, Oh IE. Incontinence and incontinence-associated dermatitis. Advances in Skin \& Wound Care 2011;24(3):124-40.

\section{Macmillan 2004}

Macmillan AK, Merrie AE, Marshall RJ, Parry BR. The prevalence of fecal incontinence in community-dwelling adults: a systematic review of the literature. Diseases of the Colon and Rectum 2004;47(8):1341-9.

\section{Newman 2007}

Newman D, Preston A, Salazar S. Moisture control, urinary and faecal incontinence, and perineal skin management. In: Krasner D, Rodeheaver G, Sibbald R editor(s). Chronic Wound Care: A

\section{CHARACTERISTICS OF STUDIES}

Characteristics of included studies [ordered by study ID]
Clinical Source Book for Healthcare Professionals. 4th Edition. Malvern: HMP Communications, 2007.

\section{NPUAP 2014}

National Pressure Ulcer Advisory Panel, European Pressure Ulcer Advisory Panel, Pan Pacific Pressure Injury Alliance. Prevention and Treatment of Pressure Ulcers: Quick Reference Guide. 2nd Edition. Perth: Cambridge Media, 2014. [Available at NPUAP-EPUAP-PPPIA Pressure Ulcer Treatment \& Prevention, 2014 Quick Reference Guide]

\section{Reference Manager 2012 [Computer program]}

Thomson Reuters. Reference Manager Professional Edition Version 12. New York: Thomson Reuters, 2012.

\section{RevMan 2014 [Computer program]}

Nordic Cochrane Centre, The Cochrane Collaboration. Review Manager 5 (RevMan 5). Version 5.3. Copenhagen: Nordic Cochrane Centre, The Cochrane Collaboration, 2014.

\section{Shamliyan 2007}

Shamliyan T, Wyman J, Bliss DZ, Kane RL, Wilt TJ. Prevention of urinary and fecal Incontinence in adults. Evidence Report/ Technology Assessment 2007;161:1-379.

\section{Sibbald 2003}

Sibbald R, Campbell K, Coutts P, Queen D. Intact Skin an integrity not to be lost. Ostomy/Wound Management 2003;49(6):27-33.

\section{References to other published versions of this review \\ Beeckman 2015b}

Beeckman D, Van Damme N, Schoonhoven L, Van Lancker A, Kottner J, Beele $\mathrm{H}$, et al. Interventions for preventing and treating incontinence-associated dermatitis in adults. Cochrane Database of Systematic Reviews 2015, Issue 4. [DOI: 10.1002/14651858.CD011627]

\section{Beeckman 2016}

Beeckman D, Van Damme N, Schoonhoven L, Van Lancker A, Kottner J, Beele $\mathrm{H}$, et al. Interventions for preventing and treating incontinence-associated dermatitis in adults. Cochrane Database of Systematic Reviews 2016, Issue 11. [DOI: 10.1002/14651858.CD011627.pub2]

* Indicates the major publication for the study

Anthony 1987

\begin{tabular}{ll} 
Methods & Randomised controlled trial \\
\hline Participants & 67 patients from different geriatric wards requiring diapers/pads \\
& Exclusion criteria: Patients with a current acute illness
\end{tabular}


Anthony 1987 (Continued)

Age (median): 81 years

Gender (men/women): 10/54

Final analysis for development of IAD and reduction of erythema was on 57 patients

Group A: 29 (4 died, had an intercurrent illness or were discharged)

Group B: 28 (6 died, had an intercurrent illness or were discharged)

Final analysis for bacteriological counts was on 43 patients

Group A: 24 (5 incomplete bacteriological data)

Group B: 19 (9 incomplete tintometric/bacteriological data)

Interventions

A: Sudocrem, liberal application with each diaper/pad change

B: Zinc oxide cream, liberal application with each diaper/pad change

Length of treatment: 14 days

Sudocrem consists of: $15.25 \%$ zinc oxide, $4.0 \%$ hydrous wool fat (hypoallergenic), $1.01 \%$ benzyl benzoate, $0.15 \%$ benzyl cinnamate and $0.39 \%$ benzyl alcohol. The zinc oxide cream consists of: $32.0 \%$ zinc oxide, $32.0 \%$ arachis oil, $0.045 \%$ calcium hydroxide, $0.5 \%$ oleic acid, $8 \%$ wool fat

Number of participants with IAD (new)
Group A: 3/16; Group B: $2 / 11$ (no significant difference between groups)
Reduction in erythema at day 7
Group A: $92.3 \%$; Group B: $37.5 \%(P<0.01)$
Reduction of erythema at day 14
Group A: $84.6 \%$; Group B: $50.0 \%(P<0.01)$
Corneocyte counts and parakeratotic cell ratios not reported
Bacteriological counts reduction
Greater reduction in bacteriological count in group A versus group B $(P<0.1)$

Notes

\section{Risk of bias}

Bias Authors' judgement Support for judgement

\begin{tabular}{ll}
\hline $\begin{array}{l}\text { Random sequence genera- } \\
\text { tion (selection bias) }\end{array}$ & Unclear risk \\
& No further information is provided.
\end{tabular}

\begin{tabular}{lll}
\hline $\begin{array}{l}\text { Allocation concealment } \\
\text { (selection bias) }\end{array}$ & Unclear risk & No information provided. \\
\hline $\begin{array}{l}\text { Blinding of participants } \\
\text { and personnel (perfor- } \\
\text { mance bias) }\end{array}$ & Unclear risk & A double-blind controlled trial. \\
All outcomes & No further information is provided. \\
\hline
\end{tabular}

Blinding of outcome as-

Unclear risk

A double-blind controlled trial. sessment (detection bias) 
Anthony 1987 (Continued)

All outcomes

\section{Incomplete outcome data High risk} (attrition bias)

All outcomes
No further information is provided.

Not clear how patients were diagnosed with IAD, and who did that.

Main outcome measure is redness, given in percentages. Not able to calculate number of patients with healing.

One or more outcomes of interest in the review are reported incompletely so
Selective reporting (reporting bias) that they cannot be entered in a meta-analysis.

High risk Insufficient information to assess whether an important risk of bias exists.

Baatenburg de Jong 2004

\begin{tabular}{|c|c|}
\hline Methods & Randomised controlled trial \\
\hline \multirow[t]{6}{*}{ Participants } & 39 nursing home patients \\
\hline & $\begin{array}{l}\text { Inclusion criteria: } 18+\text { years; incontinent of urine, faeces or both; moderate to severe redness or mod- } \\
\text { erate to severe erosion of the epidermis with mild to moderate involvement of the dermis caused by } \\
\text { urine, faeces or both in the perianal/buttocks area }\end{array}$ \\
\hline & $\begin{array}{l}\text { Exclusion criteria: other significant skin disease or dermatological problem; medical condition accord- } \\
\text { ing to the investigators opinion; participation in another trial in the previous } 30 \text { days }\end{array}$ \\
\hline & Group A: Not reported (mean age 83.3 years (SD 7.8); gender 60.0\% female; mean BMI 22.9 (SD 3.4)) \\
\hline & Group B: Not reported (mean age 85.1 years (SD 7.2); gender 73.7\% female; mean BMI 24.9 (SD 6.1)) \\
\hline & $\begin{array}{l}10 \text { patients terminated the study prematurely: } 5 \text { patients were healed, } 4 \text { died, } 1 \text { had high fever and hy- } \\
\text { potension. }\end{array}$ \\
\hline
\end{tabular}

Interventions

Group A: Zinc oxide oil according to nursing home protocol; removal of remaining zinc oxide every morning and evening before reapplication; reapplication if necessary during diaper/pad change; use of diapers

Group B: Cavilon No Sting Barrier Film (3M) every 24, 48 to 72 hours depending on skin condition and frequency of diaper change; use of diapers/pads

Length of treatment: 14 days

Outcomes

\author{
Skin condition assessment score \\ Improvement in total skin damage score in favour of group $B(P=0.04)$ \\ Redness area \\ Improved in group B compared to group A (no frequencies mentioned) \\ Reduction in redness severity \\ Group B: $47.4 \%$ versus $15.0 \%$ \\ Reduction in denudation area \\ Group B: 42.9 versus $16.7 \%$ \\ Reduction in denudation severity \\ Group B: $35.7 \%$ versus $8.3 \%$
}


Baatenburg de Jong 2004 (Continued)

\section{Product cost}

Group A: EUR 14.16 (SD 1.83); Group B: EUR 7.55 (SD 8.60)

Nursing time

Group A: 208.95 minutes (SD 53.84); Group B: 161.96 minutes (SD 55.55)

Mean cost of nursing time

Group A: EUR 88.20 (SD 22.88); Group B: EUR 68.58 (SD 23.61)

Total cost (cost of treatment, cost of trial, cost of nursing)

Group A: EUR 102.96 (SD 23.25); Group B: EUR 76.13 (SD 25.48)

Incremental cost-effectiveness (ratio of difference in mean cost between groups and mean change in skin condition on a 12-point scale)

Group A: EUR 98.06 (point improvement); Group B: EUR 28.36 (point improvement)

Notes $\quad$ Unclear in which group one patient dropped out.

\section{Risk of bias}

\begin{tabular}{|c|c|c|}
\hline Bias & Authors' judgement & Support for judgement \\
\hline $\begin{array}{l}\text { Random sequence genera- } \\
\text { tion (selection bias) }\end{array}$ & Low risk & Patients were randomised by computer. \\
\hline $\begin{array}{l}\text { Allocation concealment } \\
\text { (selection bias) }\end{array}$ & Unclear risk & Not reported. \\
\hline $\begin{array}{l}\text { Blinding of participants } \\
\text { and personnel (perfor- } \\
\text { mance bias) } \\
\text { All outcomes }\end{array}$ & High risk & Blinding impossible because of difference in product appearance and use. \\
\hline $\begin{array}{l}\text { Blinding of outcome as- } \\
\text { sessment (detection bias) } \\
\text { All outcomes }\end{array}$ & High risk & No blinding, open label trial. \\
\hline $\begin{array}{l}\text { Incomplete outcome data } \\
\text { (attrition bias) } \\
\text { All outcomes }\end{array}$ & Low risk & $\begin{array}{l}\text { One patient not included in analysis. Reason not mentioned. } 10 \text { patients termi- } \\
\text { nated the trial prematurely for the following non-trial related reasons: healing } \\
\text { (5), death (4), high fever and hypotension (1). }\end{array}$ \\
\hline $\begin{array}{l}\text { Selective reporting (re- } \\
\text { porting bias) }\end{array}$ & Low risk & $\begin{array}{l}\text { The trial protocol is available and all of the trial's prespecified outcomes that } \\
\text { are of interest in the review have been reported. }\end{array}$ \\
\hline Other bias & High risk & $\begin{array}{l}\text { Trial sponsored by } 3 \mathrm{M} \text {, who makes Cavilon, who also did the randomisation } \\
\text { and data analysis. No mention of this in the discussion, not clear how this may } \\
\text { have influenced results. }\end{array}$ \\
\hline
\end{tabular}

Beeckman 2011

\begin{tabular}{ll}
\hline Methods & Clustered randomised controlled trial \\
\hline Participants & 141 patients in 11 nursing home wards in 4 nursing homes at risk of/or affected by IAD
\end{tabular}

Participants

141 patients in 11 nursing home wards in 4 nursing homes at risk of/or affected by IAD 
Inclusion criteria: chronically incontinent for urine, stool, or double urinary and faecal incontinence and/or discolouration of the perineal kin, caused by urine or stool and not caused by pressure/shear and/or hyperhydrated skin

Exclusion criteria: admitted to hospital or admitted from another nursing home ward

Group A: 73 (mean age 86.3 years; gender (male/female): 13/60; type of incontinence (urine/faeces/both): 45/21/7)

Group B: 68 (mean age 85.9 years; gender (male/female): 15/53; type of incontinence (urine/faeces/both): 39/21/8)

IAD prevalence and severity between groups not significantly different at baseline

Group A: 22.3\%; Group B: $22.8 \%(P=0.76)$

IAD severity between groups not significantly different at baseline

Group A: 6.9/10; Group B: 7.3/10 (P = 0.99)

Interventions

Group A: Daily use of cellulose fiber/polyester premoistened washcloth (Comfort Shield Perineal Care Washcloth Dimethicone 3\%, Sage Products Inc) for routine perineal skin hygiene and after each diaper/pad change; no towel rubbing; in case of extremely soiled skin soft washcloth and lukewarm water to remove soiling was allowed and a soft towel to dry the skin; use of diapers/pads with frequency of change according to protocol of the participant ward

Group B: Daily use of soft washcloth, water and soap ( $\mathrm{pH} 6.5$ to 7.5 ) for routine perineal skin hygiene and after each diaper/pad change; no additional skin protectant was applied; use of diapers/pads with frequency of change according to protocol of the participant ward

Length of treatment: 120 days

\begin{tabular}{ll}
\hline Outcomes & Number of patients with IAD (residual) \\
& Group A: 8.1\%; Group B: $27.1 \%(t=6.3, P<0.001)$ \\
& IAD severity \\
& Group A: $3.8 / 10$; Group B: $6.4 / 10(t=3.1, P<0.03)$ \\
& Bacterial or fungal infection \\
& Group A: 0; Group B: 0
\end{tabular}

Notes

\section{Risk of bias}

Bias Authors' judgement Support for judgement

Random sequence genera- Low risk Simple randomisation was used to assign the wards to the experimental and tion (selection bias) control groups (SPSS).

\begin{tabular}{lll}
$\begin{array}{l}\text { Allocation concealment } \\
\text { (selection bias) }\end{array}$ & Unclear risk & Not reported. \\
\hline $\begin{array}{l}\text { Blinding of participants } \\
\text { and personnel (perfor- } \\
\begin{array}{l}\text { mance bias) } \\
\text { All outcomes }\end{array}\end{array} \quad$ High risk & $\begin{array}{l}\text { No blinding of participants and personnel possible due to nature of interven- } \\
\text { tion, i.e. washing with a washcloth with cleansing, moisturising and protecting } \\
\text { properties or with soap and water. }\end{array}$ \\
\hline
\end{tabular}


Beeckman 2011 (Continued)

Blinding of outcome as- High risk No blinding of participants and personnel possible due to nature of intervensessment (detection bias) tion, i.e. washing with a washcloth with cleansing, moisturising and protecting All outcomes properties or with soap and water.

Incomplete outcome data Unclear risk $\quad$ No sufficient reporting of attrition/exclusions to permit judgement.
(attrition bias)
(attrition bias)

All outcomes

\begin{tabular}{|c|c|c|}
\hline $\begin{array}{l}\text { Selective reporting (re- } \\
\text { porting bias) }\end{array}$ & Low risk & $\begin{array}{l}\text { The trial protocol is available and all of the trial's prespecified outcomes that } \\
\text { are of interest in the review have been reported. }\end{array}$ \\
\hline
\end{tabular}

Other bias Low risk

Brunner 2012

\begin{tabular}{|c|c|}
\hline Methods & Randomised controlled trial \\
\hline \multirow[t]{5}{*}{ Participants } & 64 hospitalised patients (critical and acute care) \\
\hline & Inclusion criteria: age > 18 years; incontinence; intact skin \\
\hline & $\begin{array}{l}\text { Exclusion criteria: any erosion or sore on perineal skin; skin disease; known allergies influencing skin } \\
\text { integrity }\end{array}$ \\
\hline & Group A: 31 (mean age: 68.1 years; gender (male/female): 23/8) \\
\hline & Group B: 33 (mean age: 66.4 years; gender (male/female): 20/13) \\
\hline \multirow[t]{3}{*}{ Interventions } & $\begin{array}{l}\text { Group A: No-rinse skin cleanser and moisturiser (Cavilon Skin Cleanser, 3M) and film-forming skin prod- } \\
\text { uct (Cavilon No Sting Barrier Film, 3M) }\end{array}$ \\
\hline & $\begin{array}{l}\text { Group B: Cleanser, moisturiser, barrier washcloth (Comfort Shield Perineal Care Washcloth Dime- } \\
\text { thicone 3\%; Sage Products Inc) }\end{array}$ \\
\hline & Length of treatment: not reported \\
\hline
\end{tabular}

Outcomes Number of participants with intact skin

Group A: 24; Group B: 24

Number of participants with mild skin breakdown

Group A: 6; Group B: 5

Number of participants with moderate skin breakdown

Group A: 1; Group B: 4

Number of participants with severe skin breakdown

Group A: 0; Group B: 0

Time to skin breakdown

Group A: 213.3 hours; Group B: 91.1 hours $(P=0.045)$

Cost per trial day

Group A: USD 6.59; Group B: USD $2.67(P=0.006)$ 
Brunner 2012 (Continued)

Notes

Time to skin breakdown was based on $n=6$ in both groups, unclear why the analysis was performed on 6 participants

\section{Risk of bias}

\begin{tabular}{lll}
\hline Bias & Authors' judgement & Support for judgement \\
\hline $\begin{array}{l}\text { Random sequence genera- } \\
\text { tion (selection bias) }\end{array}$ & Unclear risk & Not reported. Only mentioned randomly assigned. \\
\hline $\begin{array}{l}\text { Allocation concealment } \\
\text { (selection bias) }\end{array}$ & Unclear risk & Not reported. \\
\hline $\begin{array}{l}\text { Blinding of participants } \\
\begin{array}{l}\text { and personnel (perfor- } \\
\text { mance bias) }\end{array}\end{array}$ & High risk \\
All outcomes & & Not blinded. \\
\hline
\end{tabular}

\begin{tabular}{lll}
\hline $\begin{array}{l}\text { Blinding of outcome as- } \\
\text { sessment (detection bias) } \\
\text { All outcomes }\end{array}$ & High risk & Not blinded. \\
\hline $\begin{array}{l}\text { Incomplete outcome data } \\
\text { (attrition bias) } \\
\text { All outcomes }\end{array}$ & High risk & Attrition not reported, and no account of how missing data were dealt with. \\
\hline $\begin{array}{l}\text { Selective reporting (re- } \\
\text { porting bias) }\end{array}$ & High risk & $\begin{array}{l}\text { P values not reported for Chi2 test. } \\
\text { Statistical methods unclear (was an F-test conducted?), why were only n }=6 \\
\text { compared regarding average time for skin breakdown, duration of interven- } \\
\text { tion not reported. }\end{array}$
\end{tabular}

Other bias Unclear risk Compliance with the study protocol not controlled.

\section{Buckley 2014}

\begin{tabular}{ll}
\hline Methods & Randomised controlled trial \\
\hline Participants & 142 hospitalised patients \\
& Inclusion criteria: patients aged 12 years and older; urinary and/or faecal incontinence; IAD ; no known \\
& allergies to treatment ingredients \\
& Exclusion criteria: pre-existing pressure ulcer (grade 3 or 4) or other full thickness wound; other skin \\
condition that may affect healing; inclusion would affect medical care; treatment with IAD agents in \\
previous week \\
Group A: 73 (mean age: 59.1 years (SD 15.7); gender (male/female): 21/52; BMI: 23.7 (SD 5.5); diabetes: \\
18; bed bound: 70; IAD score (median; range): 5 (3-8)) \\
Group B: 69 (mean age: 58.8 years (SD 19.7); gender (male/female): 16/53; BMI: 22.8 (SD 5.1); diabetes: \\
15; bed bound: $68 ;$ IAD score (median; range): 6 (3-9)) \\
Final analysis for change in IAD area affected was on 121 patients \\
Group A: 65 (discharged: 4; family withdrawal: 1 ; fungal infection or medical treatment: 3)
\end{tabular}


Buckley 2014 (Continued)

Group B: 56 (discharged: 7; no reason: 1; protocol deviation: 2; fungal infection or medical treatment: 3)

Interventions Group A: $40 \%$ zinc oxide based paste (Desitin Max Strength Diaper Rash Paste) applied twice daily and after incontinence episode; scrubbing and vigorous cleansing avoided; at diaper/pad change IAD cleaned with plain saline, a polyhexanide wound cleaner, gauze pads and soft tissue

Group B: 20\% Zinc oxide based ointment (Calmoseptine ointment) applied twice daily and after incontinence episode; scrubbing and vigorous cleansing avoided; at diaper/pad change IAD cleaned with plain saline, a polyhexanide wound cleaner, gauze pads and soft tissue

Length of treatment: 6 days

Number of participants completely healed (intention-to-treat analysis)
Group A: 7 ; Group B: $15(P=0.046)$
Number of participants completely healed (per-protocol analysis)
Group A: 7 ; Group B: $14(P=0.039)$
Mean change in IAD area affected
Group A: - 40.7 (SD 174.6); Group B: $-136.6(S D 114.2)(P=0.001)$
Fungal infection: 4

Notes No mention to which group the patients with fungal infection were allocated to.

\section{Risk of bias}

\begin{tabular}{|c|c|c|}
\hline Bias & Authors' judgement & Support for judgement \\
\hline $\begin{array}{l}\text { Random sequence genera- } \\
\text { tion (selection bias) }\end{array}$ & Low risk & Randomisation was computer-generated. \\
\hline $\begin{array}{l}\text { Allocation concealment } \\
\text { (selection bias) }\end{array}$ & Low risk & $\begin{array}{l}\text { Treatment allocation was assigned by the surgical research unit, which was } \\
\text { not linked to the trial team. }\end{array}$ \\
\hline $\begin{array}{l}\text { Blinding of participants } \\
\text { and personnel (perfor- } \\
\text { mance bias) } \\
\text { All outcomes }\end{array}$ & High risk & Blinding for treatment not possible. \\
\hline $\begin{array}{l}\text { Blinding of outcome as- } \\
\text { sessment (detection bias) } \\
\text { All outcomes }\end{array}$ & Low risk & $\begin{array}{l}\text { High definition photographs were assessed by certified wound care specialists, } \\
\text { blinded to treatment allocation, independent of sponsors and investigating } \\
\text { team and not involved in any other aspect of the study (p. 16) }\end{array}$ \\
\hline $\begin{array}{l}\text { Incomplete outcome data } \\
\text { (attrition bias) } \\
\text { All outcomes }\end{array}$ & Low risk & \\
\hline $\begin{array}{l}\text { Selective reporting (re- } \\
\text { porting bias) }\end{array}$ & Low risk & Intention-to-treat analysis. All outcomes are reported. \\
\hline Other bias & Low risk & \\
\hline
\end{tabular}


Byers 1995

\begin{tabular}{|c|c|}
\hline Methods & Cross-over trial \\
\hline \multirow[t]{8}{*}{ Participants } & 10 white female residents from a US nursing home \\
\hline & Inclusion criteria: intact perineal skin \\
\hline & Exclusion criteria: Thigh-level amputations, not expected to live through the duration of the trial \\
\hline & Age (mean): 87 years \\
\hline & gender (male/female): 0/10 \\
\hline & Brader score (mean): 9 \\
\hline & Duration of incontinence (mean): 8 months \\
\hline & $\begin{array}{l}\text { Final analysis for TEWL, erythema, } \mathrm{pH} \text { and cleansing time was on } 10 \text { participants ( } 1 \text { transferred to other } \\
\text { institution and } 1 \text { died) }\end{array}$ \\
\hline \multirow[t]{7}{*}{ Interventions } & Group A (baseline/control): soap (Liquid Dial Soap, The Dial Corp) and water \\
\hline & Group B (intervention): no-rinse skin cleanser (Triple Care Cleanser, Smith \& Nephew) \\
\hline & Group C (intervention): no-rinse skin cleanser and skin protectant (Triple Care Cream, Smith \& Nephew) \\
\hline & Group D (intervention): soap and water and skin protectant \\
\hline & Group E (end/control): soap and water \\
\hline & In all groups use of diapers/pads, cleansing three times per day. \\
\hline & $\begin{array}{l}\text { Length of trial: } 15 \text { weeks, } 3 \text { weeks per group (each skin care procedure was applied in each participant } \\
\text { for three weeks, in random order) }\end{array}$ \\
\hline \multirow[t]{16}{*}{ Outcomes } & TEWL \\
\hline & Group B: 12.1; Group C: 12.8; Group D: 11.6; Group E: 15.7 \\
\hline & Group E versus group $\mathrm{B}: \mathrm{P}=0.02$ \\
\hline & Group E versus group $D: P=0.01$ \\
\hline & Group $\mathrm{E}$ versus group $\mathrm{C}: \mathrm{P}=0.03$ \\
\hline & Erythema \\
\hline & Group C: 156 Group E: $192(P=0.014)$ \\
\hline & $\mathrm{pH}$ \\
\hline & Group A: 6.88; Group B: 7.18; Group C: 7.21; Group D: 7.29; Group E: 7.50 \\
\hline & Group E versus group $B: P=0.006$ \\
\hline & Group E versus group C: $\mathrm{P}=0.04$ \\
\hline & Group $A$ versus group $D: P=0.002$ \\
\hline & Group A versus group C: $\mathrm{P}<0.001$ \\
\hline & Cleansing time \\
\hline & Urine: No-rinse skin cleanser: 0.63 Soap and water: $4.50(P<0.001)$ \\
\hline & Stool and urine: No-rinse skin cleanser: 2.95 Soap and water: $12.6(P<0.001)$ \\
\hline
\end{tabular}


Byers 1995 (Continued)
Notes
No evidence of skin break down (IAD developing) in any patient.

\section{Risk of bias}

\begin{tabular}{|c|c|c|}
\hline Bias & Authors' judgement & Support for judgement \\
\hline $\begin{array}{l}\text { Random sequence genera- } \\
\text { tion (selection bias) }\end{array}$ & Unclear risk & $\begin{array}{l}\text { Two residents were randomly assigned to each order ( } 6 \text { orders). } \\
\text { No more information is given. }\end{array}$ \\
\hline $\begin{array}{l}\text { Allocation concealment } \\
\text { (selection bias) }\end{array}$ & Unclear risk & $\begin{array}{l}\text { Two residents were randomly assigned to each order ( } 6 \text { orders). } \\
\text { No more information is given. }\end{array}$ \\
\hline $\begin{array}{l}\text { Blinding of participants } \\
\text { and personnel (perfor- } \\
\text { mance bias) } \\
\text { All outcomes }\end{array}$ & High risk & No blinding. \\
\hline $\begin{array}{l}\text { Blinding of outcome as- } \\
\text { sessment (detection bias) } \\
\text { All outcomes }\end{array}$ & High risk & No blinding. \\
\hline $\begin{array}{l}\text { Incomplete outcome data } \\
\text { (attrition bias) } \\
\text { All outcomes }\end{array}$ & Low risk & $\begin{array}{l}12 \text { residents were initially selected, data from } 10 \text { residents were available for } \\
\text { analysis. } \\
1 \text { resident was transferred to a nursing home closer to her family; and } 1 \text { resi- } \\
\text { dent died of unrelated causes. }\end{array}$ \\
\hline $\begin{array}{l}\text { Selective reporting (re- } \\
\text { porting bias) }\end{array}$ & Low risk & $\begin{array}{l}\text { The trial protocol is available and all of the trial's prespecified outcomes that } \\
\text { are of interest in the review have been reported. }\end{array}$ \\
\hline Other bias & High risk & $\begin{array}{l}\text { Cross-over design without washout periods. } \\
\text { 'Compliance with regimen was controlled.' }\end{array}$ \\
\hline
\end{tabular}

Conley 2014

\begin{tabular}{|c|c|}
\hline Methods & Randomised controlled trial \\
\hline \multirow[t]{6}{*}{ Participants } & 99 residents from Progressive Care Unit \\
\hline & $\begin{array}{l}\text { Inclusion criteria: age > } 18 \mathrm{yrs} \text {; incontinence of urine and/or faeces; surgical patients who had an in- } \\
\text { dwelling urinary catheter for > } 2 \text { days; patients who had a urinary catheter for any other length of time; } \\
\text { patients with a rectal tube in situ for liquid stool }\end{array}$ \\
\hline & Exclusion criteria: Patients admitted from other units, outside facilities, or home \\
\hline & $\begin{array}{l}\text { Group A: } 55 \text { (mean age: } 75 \text { years; gender (male/female): 32/23; incontinence (urinary/bowel): 18/37; no } \\
\text { dermatitis 20, mild/light red 22, moderate/red 5, severe/red 0; average number of length of stay: } 9.13 \\
\text { days; average Braden score: } 15 \text { ) }\end{array}$ \\
\hline & $\begin{array}{l}\text { Group B: } 44 \text { (mean age: } 67 \text { years, gender (male/female): 19/25; incontinence (urinary/bowel): 17/27; no } \\
\text { dermatitis 12, mild/light red 15, moderate/red 6, severe/red 2; average number of length of stay: } 8.75 \\
\text { days; average Braden score: 14) }\end{array}$ \\
\hline & $\begin{array}{l}\text { Differences: patients in group B were younger, but were more often affected by IAD and showed higher } \\
\text { severity. Group A had more patients receiving enteral nutrition }(21.8 \%) \text { than controls }(5.5 \%)(P<0.001) \text {; }\end{array}$ \\
\hline
\end{tabular}


Conley 2014 (Continued)

control group had more patients on pureed diet $(23.6 \%)$ than intervention group $(3.6 \%)(P<0.001)$; no significant difference reported for other measures at baseline (e.g. serum albumin, Braden score)

Interventions

Group A: skin care protocol performed every 6 hours and as needed

Group B: skin care protocol performed every 12 hours and as needed

Both groups: skin care protocol: gently skin cleansing with cleanser containing Aloe vera, water, cleansing lotion; after cleansing skin was patted dry; if no erythema application of a leave-on product including silicone; if erythema present application of a leave-on product with including zinc oxide and menthol

Co-interventions: All nursing staff were given education on IAD and scoring erythema

Length of trial: 9 months

$\begin{array}{ll}\text { Outcomes } & \text { No dermatitis } \\ & \text { Group A: 43.6\%; Group B: } 40 \%(P=0.718) \\ & \text { Mild/light red } \\ & \text { Group A: 43.6\%; Group B: } 25.5 \%(P<0.001) \\ & \text { Moderate/red } \\ & \text { Group A: } 7.1 \% \text {; Group B: } 10.9 \%(P<0.001) \\ & \text { Severe/red } \\ & \text { Group A: } 1.9 \% \text {; Group B: } 1.8 \%(P=0.898)\end{array}$

Notes Impossible to distinguish between prevention and treatment.

\section{Risk of bias}

\begin{tabular}{lll}
\hline Bias & Authors' judgement & Support for judgement \\
\hline $\begin{array}{l}\text { Random sequence genera- } \\
\text { tion (selection bias) }\end{array}$ & High risk & $\begin{array}{l}\text { To randomise the patients, those enrolled on even numbered days were put in } \\
\text { the intervention group. Those enrolled on odd numbered days were put in the } \\
\text { control group. Non-random component in the sequence generation process. }\end{array}$ \\
\hline
\end{tabular}

Allocation concealment High risk Odd and even days used. Allocation can be foreseen.

(selection bias)

\begin{tabular}{|c|c|c|}
\hline $\begin{array}{l}\text { Blinding of participants } \\
\text { and personnel (perfor- }\end{array}$ & High risk & $\begin{array}{l}\text { No blinding, also not possible due to nature of intervention: skin care every } 12 \\
\text { or every } 6 \text { hours. }\end{array}$ \\
\hline
\end{tabular}
mance bias)

All outcomes

\begin{tabular}{lll}
\hline $\begin{array}{l}\text { Blinding of outcome as- } \\
\text { sessment (detection bias) } \\
\text { All outcomes }\end{array}$ & High risk & No blinding. \\
\hline $\begin{array}{l}\text { Incomplete outcome data } \\
\text { (attrition bias) }\end{array}$ & Low risk & $\begin{array}{l}\text { No incomplete data reported. Table with outcomes reports same numbers at } \\
\text { admission and discharge. } 99 \text { patients reported and } 99 \text { included. }\end{array}$ \\
$\begin{array}{l}\text { All outcomes } \\
\text { Patients were terminated from the trial upon transfer to another unit, dis- } \\
\text { charge home, discharge to another facility or death. Insufficient reporting of } \\
\text { attrition/exclusions to permit judgement. }\end{array}$
\end{tabular}


Conley 2014 (Continued)

$\begin{array}{ll}\begin{array}{l}\text { Selective reporting (re- } \\ \text { porting bias) }\end{array} \quad \text { Low risk } & \begin{array}{l}\text { The trial protocol is available and all of the trial's prespecified outcomes that } \\ \text { are of interest in the review have been reported }\end{array}\end{array}$

Other bias Unclear risk Insufficient information to assess whether an important risk of bias exists

\section{Cooper 2001}

\begin{tabular}{|c|c|}
\hline Methods & Randomised Controlled Trial \\
\hline \multirow[t]{6}{*}{ Participants } & 93 elderly patients from elderly care homes and hospitals \\
\hline & $\begin{array}{l}\text { Inclusion criteria: any patient suffering urinary incontinence, faecal incontinence, both, catheterised } \\
\text { and bypassing urine. }\end{array}$ \\
\hline & Exclusion criteria: none described \\
\hline & $\begin{array}{l}\text { Group A: } 49 \text { (median age: } 79 \text { years (IQR } 73.5,86.5 \text { ); gender (male/female): } 22 / 27 \text {; nursing home resi- } \\
\text { dents/hospital patients: } 28 / 21 \text {; median length of stay median: } 0.38 \text { years; healthy skin: } 33 \text {; erythema: } 9 \text {; } \\
\text { broken skin: 5; average no. incontinence episodes per } 24 \text { hours: } 4 \text {; changes in mobility: } 6 \text { ) }\end{array}$ \\
\hline & $\begin{array}{l}\text { Group B: } 44 \text { (median age: } 85 \text { years (IQR } 79.8,89.3 \text { ); gender (male/female): } 9 / 35 \text {; nursing home resi- } \\
\text { dents/hospital patients: 20/24; median length of stay median: } 1.72 \text { years; healthy skin: } 33 \text {; erythema: } 5 \text {; } \\
\text { broken skin: 3; average no. incontinence episodes per } 24 \text { hours: } 5 \text {; changes in mobility: } 8 \text { ) }\end{array}$ \\
\hline & $\begin{array}{l}\text { Data complete for analysis on skin deterioration was on } 87 \text { patients. Gender difference between groups } \\
\text { (statistical significance not reported) }\end{array}$ \\
\hline \multirow[t]{5}{*}{ Interventions } & Group A: hospital soap (unperfumed and $\mathrm{pH}$ 9.5-10.5 (1\% aqueous solution)) and water \\
\hline & $\begin{array}{l}\text { Group B: Clinisan (Vernacare; skin cleanser with pH } 5.5 \text { - contains surfactant, emollients, dimethicone, } \\
\text { antibacterial agent, perfume) }\end{array}$ \\
\hline & Both groups: Other skin protectants stopped \\
\hline & Co-interventions: All nursing staff were given education by researcher \\
\hline & Length of follow-up: 10 months (follow-up 14 days) \\
\hline
\end{tabular}

\section{Outcomes}

Number of patients with healthy skin

Group A: $17 / 46$ (37\%); Group B: $27 / 41(66 \%)$

Number of patients with deterioration of skin integrity

Group A: 14/46 (30\%); Group B: 5/41 (12\%)

\section{Notes}

\section{Risk of bias}

\begin{tabular}{lll}
\hline Bias & Authors' judgement & Support for judgement \\
\hline $\begin{array}{l}\text { Random sequence genera- } \\
\text { tion (selection bias) }\end{array}$ & Low risk & Patients were randomised by unmarked envelopes. \\
& No further information is given. \\
\hline $\begin{array}{l}\text { Allocation concealment } \\
\text { (selection bias) }\end{array}$ & Unclear risk & No clear description of concealment. No description of envelopes. \\
\hline
\end{tabular}


Cooper 2001 (Continued)

Blinding of participants High risk Not reported. Not possible due to differences in treatment and personnel (perfor-

mance bias)

All outcomes

Blinding of outcome as-
sessment (detection bias) $\quad$ Low risk Blinded assessment by two experts of outcomes using photographs.

All outcomes

\begin{tabular}{lll}
\hline $\begin{array}{l}\text { Incomplete outcome data } \\
\text { (attrition bias) } \\
\begin{array}{l}\text { All outcomes } \\
\text { Selective reporting (re- }\end{array}\end{array}$ & Low risk & $\begin{array}{l}\text { Six patients not included in analysis for the following reasons: non-compliance } \\
\text { (2), transfer to acute hospital (1), application of skin protectants in error (2) } \\
\text { and development of superficial blistering on the tights (1) }\end{array}$ \\
\hline \begin{tabular}{l} 
porting bias) \\
\hline
\end{tabular} & $\begin{array}{l}\text { The trial protocol is available and all of the trial's prespecified outcomes that } \\
\text { are of interest in the review haven been reported. }\end{array}$
\end{tabular}

Other bias Low risk

Dieter 2006

\begin{tabular}{ll}
\hline Methods & Randomised controlled trial \\
\hline Participants & 94 patients from 3 adult medical/surgical hospital units \\
& Group A: 28 ; Group B: 35 ; Group C: 31 \\
\hline
\end{tabular}

Group A: cleansing spray, washcloth, leave-on product
Group B: disposable washcloth with cleansing, moisturising and skin protecting properties (dime-
thicone)
Group C: disposable washcloth (discontinued at 4 weeks because of high rate of skin problems (29\%)
per incontinent episode)

\begin{tabular}{|c|c|c|}
\hline \multirow[t]{6}{*}{ Outcomes } & \multirow{2}{*}{\multicolumn{2}{|c|}{$\begin{array}{l}\text { Number of skin problems } \\
\text { Group A: 14; Group B: } 18\end{array}$}} \\
\hline & & \\
\hline & \multicolumn{2}{|c|}{ Number of patients with skin problems } \\
\hline & \multicolumn{2}{|l|}{ Group A: 6; Group B: 7} \\
\hline & \multicolumn{2}{|c|}{ Average cost of treatment per patient } \\
\hline & \multicolumn{2}{|c|}{ Group A: USD 6.13; Group B: USD 5.40} \\
\hline Notes & \multicolumn{2}{|c|}{ Data extraction was based on an abstract. The authors did not respond to our request for more details. } \\
\hline \multicolumn{3}{|l|}{ Risk of bias } \\
\hline Bias & Authors' judgement & Support for judgement \\
\hline $\begin{array}{l}\text { Random sequence genera- } \\
\text { tion (selection bias) }\end{array}$ & High risk & Based on the last digit of medical record number. \\
\hline $\begin{array}{l}\text { Allocation concealment } \\
\text { (selection bias) }\end{array}$ & High risk & Based on the last digit of medical record number. \\
\hline
\end{tabular}


Dieter 2006 (Continued)

Blinding of participants High risk Not possible due to visual differences between the interventions. and personnel (perfor-

mance bias)

All outcomes

\begin{tabular}{|c|c|c|}
\hline $\begin{array}{l}\text { Blinding of outcome as- } \\
\text { sessment (detection bias) } \\
\text { All outcomes }\end{array}$ & Unclear risk & Not reported. \\
\hline $\begin{array}{l}\text { Incomplete outcome data } \\
\text { (attrition bias) } \\
\text { All outcomes }\end{array}$ & Unclear risk & Attrition and exclusions not reported. \\
\hline $\begin{array}{l}\text { Selective reporting (re- } \\
\text { porting bias) }\end{array}$ & High risk & $\begin{array}{l}\text { Trial protocol not available, abstract. } \\
\text { P values not reported. }\end{array}$ \\
\hline Other bias & Unclear risk & Study described in an abstract, without sufficient details. \\
\hline
\end{tabular}

\section{Kennedy 1996}

\begin{tabular}{|c|c|}
\hline Methods & Randomised controlled Trial \\
\hline \multirow[t]{10}{*}{ Participants } & 40 subjects from health centre \\
\hline & Inclusion criteria: history of incontinence, urine, faeces or both; moderate skin breakdown \\
\hline & Exclusion criteria: not reported \\
\hline & Group A: 8 \\
\hline & Group B: 8 \\
\hline & Group C: 8 \\
\hline & Group D: 8 \\
\hline & Group E: 8 \\
\hline & $\begin{array}{l}\text { All patients: } 40 \text { (age: not reported; Gender (male/female): not reported; Type of incontinence (uri- } \\
\text { nary/faecal/both): 32/4/4; mean Braden score: } 13.6 \text { (SD 0.5); mean skin condition score: } 6.0 \text { (SD 0.3)) }\end{array}$ \\
\hline & $\begin{array}{l}\text { No statistically significant differences regarding Braden mean score between groups; no statistically } \\
\text { significant differences regarding mean frequencies of incontinence episodes between groups }\end{array}$ \\
\hline \multirow[t]{6}{*}{ Interventions } & $\begin{array}{l}\text { Group A: received petrolatum ointment (Peri-Care, Sween) three times per day and as necessary during } \\
12 \text { days }\end{array}$ \\
\hline & Group B: received zinc oxide cream (Baza, Sween) three times per day and as necessary during 12 days \\
\hline & Group C: received Cavilon No Sting Barrier Film (3M) every 24 hours during 12 days \\
\hline & Group D: received No Sting Barrier Film every 48 hours during 12 days \\
\hline & Group E: received No Sting Barrier Film every 72 hours during 12 days \\
\hline & Length of treatment: six months \\
\hline
\end{tabular}


Skin condition scores decreased in all five groups (Figure 5, page 69)

"There were no significant differences in skin condition among the five treatment groups at any time during the trial" (page 69)

Amount of product use per day

Group A: 13.6 g (SD 1.9); Group B: 16.1 g (SD 2.2); Group C: one applicator per patient per application; Group D: one applicator per patient per application; Group E: one applicator per patient per application

Cost per day

Group A: USD 0.8; Group B: USD 1.2; Group C: USD 2.3; Group D: USD 1.1; Group E: USD 0.8

Notes

Funding 3M Healthcare (Cavilon NSBF).

Skin condition scores difficult to interpret.

\section{Risk of bias}

Bias Authors' judgement Support for judgement

Random sequence genera- Unclear risk Random assignment. No further information provided. tion (selection bias)

\begin{tabular}{lll}
\hline $\begin{array}{l}\text { Allocation concealment } \\
\text { (selection bias) }\end{array}$ & Unclear risk & Not reported. \\
\hline $\begin{array}{l}\text { Blinding of participants } \\
\text { and personnel (perfor- } \\
\text { mance bias) }\end{array}$ & High risk & No blinding. \\
All outcomes & & Blinding not possible due to difference in products.
\end{tabular}

\begin{tabular}{lll}
\hline $\begin{array}{l}\text { Blinding of outcome as- } \\
\text { sessment (detection bias) } \\
\text { All outcomes }\end{array}$ & High risk & No blinding. \\
\hline $\begin{array}{l}\text { Incomplete outcome data } \\
\text { (attrition bias) } \\
\text { All outcomes }\end{array}$ & Unclear risk & No incomplete data reported, insufficient reporting of attrition/exclusion. \\
\hline $\begin{array}{l}\text { Selective reporting (re- } \\
\text { porting bias) }\end{array}$ & High risk & $\begin{array}{l}\text { One or more outcomes of interest in the review are reported incompletely so } \\
\text { that they cannot be entered in a meta-analysis. Only average scores are men- } \\
\text { tioned. } \\
\end{array}$ \\
\hline Other bias & Unclear risk & Funded by 3M Healthcare. \\
\hline
\end{tabular}

Lewis-Byers 2002

\begin{tabular}{ll}
\hline Methods & Randomised Controlled Trial \\
\hline Participants & 31 nursing home residents \\
& Inclusion criteria: incontinent for urine, stool or both \\
& Exclusion criteria: indwelling catheters \\
\hline
\end{tabular}


Lewis-Byers 2002 (Continued)

Group A: 18 (range age: 41-78; gender (male/female): 4/14; type of incontinence (urine/faeces/both): $1 / 4 / 13$; baseline skin condition rating normal skin: 15 ; redness, slight rash: 1 ; intense redness: 0 ; redness, small blisters: 2 ; skin erosion, loss of skin: 0 )

Group B: 14 (range age: 63-105; gender (male/female): 1/13; type of incontinence (urine/faeces/both): 2/0/11; baseline skin condition rating normal skin: 9 ; redness, slight rash: 1 ; intense redness: 3 ; redness, small blisters: 0; skin erosion, loss of skin: 0 )

Interventions

Group A: cleansing with Cavilon Antiseptic Skin Cleanser (3M); during first incontinent episode per shift Cavilon Durable Barrier Cream (3M) was applied

Group B: cleansing with soap (liquid or bar) and disposable washcloth and water followed by application of a lotion

Both groups: cleansing after each incontinent episode

Length of treatment: 3 weeks

Outcomes
Skin condition score
Group A: 0.28 (SD 0.83); Group B: 0.77 (SD 1.30); not statistically significant (P value not reported)
Pain score
Group A: 0.11 (SD 0.47); Group B: 0.77 (SD 1.30); not statistically significant (P value not reported)
Skin cleansing time including preparation
Group A: 5 minutes per cleansing; 41 minutes per day; Group B: 13 minutes per cleansing; 120 minutes
per day
Means and standard deviations of skin conditions and pain scores identical in group 1 (Table 3, page
49). Unclear whether this is correct or a typing error.
Time was measured for an unknown subset of residents and modelled.

\section{Risk of bias}

\begin{tabular}{lll}
\hline Bias & Authors' judgement & Support for judgement \\
\hline $\begin{array}{l}\text { Random sequence genera- } \\
\text { tion (selection bias) }\end{array}$ & High risk & $\begin{array}{l}\text { Patients were randomly assigned. Residents in even numbered rooms were as- } \\
\text { signed to the control group, residents in odd numbered rooms were assigned } \\
\text { to the trial protocol. }\end{array}$ \\
\hline $\begin{array}{l}\text { Allocation concealment } \\
\text { (selection bias) }\end{array}$ & High risk & Not present. \\
\hline $\begin{array}{l}\text { Blinding of participants } \\
\text { and personnel (perfor- } \\
\text { mance bias) } \\
\text { All outcomes }\end{array}$ & High risk & No blinding. \\
\hline
\end{tabular}

\begin{tabular}{|c|c|}
\hline $\begin{array}{l}\text { Blinding of outcome as- } \\
\text { sessment (detection bias) } \\
\text { All outcomes }\end{array}$ & High risk \\
\hline
\end{tabular}

$\begin{array}{ll}\begin{array}{l}\text { Incomplete outcome data } \\ \text { (attrition bias) } \\ \text { All outcomes }\end{array} & \begin{array}{l}\text { One patient not included in analysis. Reason not mentioned. One patient ter- } \\ \text { minated the trial prematurely as result of regained continence. }\end{array}\end{array}$


Lewis-Byers 2002 (Continued)

$\begin{array}{ll}\begin{array}{l}\text { Selective reporting (re- } \quad \text { Low risk } \\ \text { porting bias) }\end{array} & \begin{array}{l}\text { The trial protocol is available and all of the trial's prespecified outcomes that } \\ \text { are of interest in the review haven been reported. }\end{array}\end{array}$

$\begin{array}{ll}\text { Other bias } \quad \text { Unclear risk } & \begin{array}{l}\text { Corresponding author was a member of the company delivering the trial prod- } \\ \text { ucts. }\end{array}\end{array}$

\section{Schoonhoven 2015}

\begin{tabular}{ll}
\hline Methods & Clustered randomised controlled trial \\
\hline Participants & 500 nursing home residents; mean age 82.4 (SD 8.3); gender $71.0 \%$ female \\
& Inclusion criteria: elderly residents receiving bathing assistance \\
& Exclusion criteria: residents who showered or bathed in bath tub more than once a week; too sick to \\
participate & \\
Group A: 290 (mean age 81.8 (SD 8.7); gender $70.7 \%$ female; BMI $25.4 \mathrm{~kg} / \mathrm{m}^{2}(\mathrm{SD} 5.4)$ ) \\
Group B: 210 (mean age 83.3 (SD 7.5); gender $71.4 \%$ female; BMI $25.4 \mathrm{~kg} / \mathrm{m}^{2}(\mathrm{SD} 6.0)$ ) \\
Final analysis was on 450 residents (Group A: 257 ; Group B 193)
\end{tabular}

Group A: Provision of bed bath with disposable wash cloths impregnated with lotion; heated in mi-
crowave before use; no towel drying
Group B: Provision of daily bad bath using tap water, washbowls, soap (different types), wash gloves
and towels
Length of treatment: 6 weeks

\begin{tabular}{ll}
\hline Outcomes & Prevalence of any skin abnormalities \\
& Group A: $72.7 \%$; Group B: $77.6 \%$ \\
& Treatment x time interaction P $=0.04$ \\
& Prevalence of significant skin lesions \\
& Group A: $36.0 \%$ Group B: $38.0 \%$ \\
& Treatment x time interaction $P=0.82$ \\
& Prevalence of resistance \\
& Group A: $12.4 \%$; Group B: $9.4 \%$ \\
& Treatment x time interaction P $=0.71$ \\
\hline Notes & Outcomes were not of interest for this review. \\
\hline Risk of bias & Authors' judgement Support for judgement \\
\hline Bias & Low risk \\
\hline Random sequence genera- & \\
\hline tion (selection bias) & Randomisation by independent statistician. \\
\hline
\end{tabular}


Schoonhoven 2015 (Continued)

$\begin{aligned} & \text { Allocation concealment } \\ & \text { (selection bias) }\end{aligned}$
Unclear risk Not reported.

Blinding of participants High risk Blinding not possible due to visual differences between the interventions.
and personnel (perfor-
mance bias)
All outcomes

\begin{tabular}{lll}
\hline Blinding of outcome as- & High risk & No blinding. Analysis by blinded statistician. \\
sessment (detection bias)
\end{tabular}

sessment (detection bias)

All outcomes

\begin{tabular}{|c|c|c|}
\hline $\begin{array}{l}\text { Incomplete outcome data } \\
\text { (attrition bias) } \\
\text { All outcomes }\end{array}$ & Unclear risk & $\begin{array}{l}\text { Unclear consideration of losses of follow-up. denominator of prevalence of } \\
\text { skin lesions } n=500 \text { (table } 3 \text {, page } 116 \text { ), but } n=50 \text { were lost during the study. }\end{array}$ \\
\hline $\begin{array}{l}\text { Selective reporting (re- } \\
\text { porting bias) }\end{array}$ & Low risk & No selective reporting apparent. \\
\hline Other bias & Low risk & \\
\hline
\end{tabular}

\section{Wang 2011}

\begin{tabular}{|c|c|}
\hline Methods & Randomised controlled trial \\
\hline \multirow[t]{4}{*}{ Participants } & 62 in hospital patients with faecal incontinence lasted for 6 to 21 days \\
\hline & $\begin{array}{l}\text { Inclusion criteria: long-term immobilisation; aged more than } 80 \text { years old; faecal incontinence with pe- } \\
\text { rianal skin damage. }\end{array}$ \\
\hline & Group A: 31; Group B: 31 \\
\hline & $\begin{array}{l}\text { No differences between patients in the intervention and the control group at baseline for age, gender } \\
\text { and severity of patient's condition }\end{array}$ \\
\hline \multirow[t]{3}{*}{ Interventions } & $\begin{array}{l}\text { Group A: cleansing of the perianal region after bowel spray with Dermlin (advanced wound healing } \\
\text { product) }\end{array}$ \\
\hline & $\begin{array}{l}\text { Group B: cleansing of the perianal region after bowel spray with Genetime (recombinant human epi- } \\
\text { dermal growth factor) }\end{array}$ \\
\hline & Length of treatment: observation of the results after five days of treatment \\
\hline \multirow[t]{2}{*}{ Outcomes } & Proportion of patients with IAD healed (predefined outcome) \\
\hline & Not clearly described, translation from Chinese \\
\hline
\end{tabular}

\section{Risk of bias}

\section{Bias}

Authors' judgement Support for judgement

Random sequence genera- Unclear risk Unclear from Chinese translation.


Wang 2011 (Continued)

$\begin{aligned} & \text { Allocation concealment } \\ & \text { (selection bias) }\end{aligned} \quad$ Unclear risk $\quad$ Unclear from Chinese translation.

Blinding of participants High risk Not possible due to visual differences between the skin care products. and personnel (performance bias)

All outcomes

Blinding of outcome as- Unclear risk Unclear from Chinese translation.
sessment (detection bias)

All outcomes

\begin{tabular}{lll}
\hline $\begin{array}{l}\text { Incomplete outcome data } \\
\text { (attrition bias) } \\
\text { All outcomes }\end{array}$ & Unclear risk & Unclear from Chinese translation. \\
\hline $\begin{array}{l}\text { Selective reporting (re- } \\
\text { porting bias) }\end{array}$ & Unclear risk & Unclear from the Chinese translation. \\
\hline Other bias & Unclear risk & $\begin{array}{l}\text { Unclear from the Chinese translation, rather short report (two pages in the } \\
\text { journal). }\end{array}$ \\
\hline
\end{tabular}

BMI: body mass index

IAD: incontinence-associated dermatitis

IQR: inter-quartile range

SD: standard deviation

SPSS: Statistical Package for the Social Sciences (IBM)

TEWL: trans-epidermal water loss

Characteristics of excluded studies [ordered by study ID]

\begin{tabular}{ll}
\hline Study & Reason for exclusion \\
\hline Al-Samarrai 2007 & No topical skin care product studied: method for improving protocol compliance. \\
\hline Bates-Jensen 2003 & No topical skin care products studied: an exercise and incontinence intervention. \\
\hline Bauer 2007 & Report of a study protocol. Trial authors contacted for more information but no response received. \\
\hline Bennett 1998 & No topical skin care products studied: low air loss hydrotherapy. \\
\hline Bliss 2007 & No randomised controlled trial. \\
\hline Brown 1994 & No topical skin care products studied: diapers and pads. \\
\hline Dealey 1995 & No randomised controlled trial: a preliminary trial. \\
\hline Denat 2011 & No topical skin care products studied: perianal pouch and adult containment brief. \\
\hline Fader 2003 & No topical skin care products studied: absorbent pads. \\
\hline Harries 2016 & Study concerning the effectiveness of implementation strategies not effectiveness of products/pro- \\
\hline cedures
\end{tabular}




\begin{tabular}{|c|c|}
\hline Study & Reason for exclusion \\
\hline Iraji 2003 & Pediatric population. \\
\hline James 1975 & Pediatric population. \\
\hline Kyung 2014 & No randomised controlled trial: no random allocation of participants. \\
\hline Leiby 1994 & No topical skin care products studied: reusable underpads. \\
\hline Lyder 1992 & No randomised controlled trial: no random allocation of participants. \\
\hline NCT02475512 2015 & Study was finished prematurely, no reliable results possible \\
\hline Netta-Turner 2008 & No topical skin care products studied: rectal trumpet. \\
\hline Pinedo 2012 & $\begin{array}{l}\text { No intervention for preventing or treating incontinence-associated dermatitis: intervention to de- } \\
\text { crease the rate of faecal incontinence. }\end{array}$ \\
\hline Pittman 2012 & $\begin{array}{l}\text { No topical skin care products studied: bowel management system catheter, rectal/nasopharyngeal } \\
\text { trumpet. }\end{array}$ \\
\hline Shin 2012 & No topical skin care products studied: uncoated paper. \\
\hline Su 2015 & No topical skin care products studied: suspension positioning system. \\
\hline Sugama 2012 & No topical skin care products studied: improved absorbent pad. \\
\hline Zehrer 2004 & No randomised controlled trial: descriptive trial. \\
\hline
\end{tabular}

\section{Characteristics of studies awaiting assessment [ordered by study ID]}

Kajii 2005

\begin{tabular}{ll}
\hline Methods & Clustered randomised controlled trial \\
\hline Participants & $\begin{array}{l}101 \text { elderly from } 5 \text { hospitals and health care facilities for elderly, who used a diaper for their incon- } \\
\text { tinence } \\
\text { Age (average): } 84.9\end{array}$ \\
\hline Group A: skin protection cleaning foam 2 times per day \\
Group B: skin protection cleaning foam 4 times per day \\
Group C: conventional care using warm water \\
Length of treatment: 6 days \\
The amount of moisture \\
Group A: 53.6 (SD 10.0) \\
Group B: 70.5 (SD 9.1) \\
Group C: 49.7 (SD 7.2) \\
The amount of sebum
\end{tabular}


Kajii 2005 (Continued)

$$
\text { Group A: } 2.1 \text { (SD 3.1) }
$$

Group B: 5.0 (SD 5.4)

Group C: 1.5 (SD 1.5)

Notes $\quad$ A translation is awaited.
The outcomes reported were not of interest for this review.

SD: standard deviation

Characteristics of ongoing studies [ordered by study ID]

NCT02570139 2015

Trial name or title

Methods

Participants

Clinical Study to Assess a New Barrier Film's Ability to Provide Skin Protection Against Incontinence \& Allow Healing

Randomised controlled trial

102 patients

admitted to a nursing care facility, with

severe Category 2 Incontinence-Associated Dermatitis - red with skin breakdown (i.e. skin erosion and denudation or denudation of skin alone)?

Age: 36 weeks (or greater gestational age) or older

\begin{tabular}{ll}
\hline Interventions & Group A: Cavilon Advanced High Endurance Skin Protectant Product applied 3x/per week. \\
Group B: ConvaTec Sensi-Care Protective Barrier applied following manufacturer's recommenda- \\
tion \\
Length of treatment: 21 days depending on length of hospitalisation
\end{tabular}

\begin{tabular}{ll}
\hline Outcomes & Reduction in dermatitis scores \\
& Re-epithelialization to a category 1 or lower \\
& Reduction in pain scores \\
Prevention of IAD
\end{tabular}

\begin{tabular}{ll}
\hline Starting date & October 2016 \\
\hline Contact information & Mary Mathisen, BS \\
& Bruce Ekholm, MS \\
\hline
\end{tabular}

Notes

\section{NCT02690753 2016}

Trial name or title

Pressure Ulcer Prevention: a Turn and Positioning System Combined With Incontinence Care and Tailored/Standard Repositioning 
NCT02690753 2016 (Continued)

Methods Randomised controlled trial

\section{Participants}

226 patients at risk of developing pressure ulcers (Braden < 17), free of pressure ulcers category II, III, IV and IAD category 2 at the start of the study

Age: 18 years and older

Interventions

Group A: a repositioning protocol tailored to individual risk factors, use of the Prevalon Turn and Position System 2.0 Device (for turning and positioning patients at risk when laying in bed). and use of Comfort Shield Barrier Cream Cloths (for incontinence care every morning and after each episode of incontinence)

Group B: standard repositioning, use of the Prevalon Turn and Position System 2.0 Device. and use of Comfort Shield Barrier Cream Cloths

Group C: usual care

Length of treatment: 8 days

\begin{tabular}{ll}
\hline Outcomes & Turning compliance of nurses \\
& Turning angle \\
& Sacrum free of pressure \\
& Incidence of pressure ulcers and incontinence-associated dermatitis \\
& Comfort and preferences of the caregiver \\
& Comfort and tolerance of the patient \\
& Cost-effectiveness of the prevention of pressure ulcers \\
\hline Starting date & February 2016 \\
\hline Contact information & Dimitri Beeckman, PhD \\
\hline Notes & \\
\hline
\end{tabular}

\section{DATA AND ANALYSES}

\section{Comparison 1. Any topical skin care product versus another topical skin care product}

\begin{tabular}{|c|c|c|c|c|}
\hline Outcome or subgroup title & No. of studies & $\begin{array}{l}\text { No. of partici- } \\
\text { pants }\end{array}$ & Statistical method & Effect size \\
\hline $\begin{array}{l}1 \text { Number of participants with IAD (resid- } \\
\text { ual, i.e. not healed) }\end{array}$ & 2 & & $\begin{array}{l}\text { Risk Ratio (M-H, Fixed, } \\
95 \% \mathrm{Cl})\end{array}$ & $\begin{array}{l}\text { Totals not select- } \\
\text { ed }\end{array}$ \\
\hline $\begin{array}{l}1.1 \text { No-rinse skin cleanser and skin cream } \\
\text { (A) versus soap and water and lotion (B) }\end{array}$ & 1 & & $\begin{array}{l}\text { Risk Ratio (M-H, Fixed, } \\
95 \% \mathrm{Cl})\end{array}$ & $0.0[0.0,0.0]$ \\
\hline 1.2 Desitin $(A)$ versus Calmoseptine (B) & 1 & & $\begin{array}{l}\text { Risk Ratio (M-H, Fixed, } \\
95 \% \mathrm{Cl})\end{array}$ & $0.0[0.0,0.0]$ \\
\hline
\end{tabular}




\begin{tabular}{|c|c|c|c|c|}
\hline Outcome or subgroup title & No. of studies & $\begin{array}{l}\text { No. of partici- } \\
\text { pants }\end{array}$ & Statistical method & Effect size \\
\hline 2 Number of participants with IAD (new) & 3 & & $\begin{array}{l}\text { Risk Ratio (M-H, Fixed, } \\
95 \% \mathrm{Cl})\end{array}$ & $\begin{array}{l}\text { Totals not select- } \\
\text { ed }\end{array}$ \\
\hline $\begin{array}{l}2.1 \text { Skin cleanser }(A) \text { versus soap and wa- } \\
\operatorname{ter}(B)\end{array}$ & 1 & & $\begin{array}{l}\text { Risk Ratio (M-H, Fixed, } \\
95 \% \mathrm{Cl})\end{array}$ & $0.0[0.0,0.0]$ \\
\hline $\begin{array}{l}2.2 \text { Sudocrem (A) versus zinc oxide cream } \\
\text { (B) }\end{array}$ & 1 & & $\begin{array}{l}\text { Risk Ratio (M-H, Fixed, } \\
95 \% \mathrm{Cl})\end{array}$ & $0.0[0.0,0.0]$ \\
\hline $\begin{array}{l}2.3 \text { No-rinse skin cleanser/moisturiser } \\
\text { and film-forming skin product }(\mathrm{A}) \text { versus } \\
\text { cleansing/moisturising/skin protecting } \\
\text { washcloth (B) }\end{array}$ & 1 & & $\begin{array}{l}\text { Risk Ratio (M-H, Fixed, } \\
95 \% \mathrm{Cl})\end{array}$ & $0.0[0.0,0.0]$ \\
\hline $\begin{array}{l}3 \text { Surface affected by IAD (measurement } \\
\text { of size of lesion) }\end{array}$ & 1 & & $\begin{array}{l}\text { Mean Difference (IV, Fixed, } \\
95 \% \mathrm{CI} \text { ) }\end{array}$ & $\begin{array}{l}\text { Totals not select- } \\
\text { ed }\end{array}$ \\
\hline 3.1 Desitin (A) versus Calmoseptine (B) & 1 & & $\begin{array}{l}\text { Mean Difference (IV, Fixed, } \\
95 \% \mathrm{CI} \text { ) }\end{array}$ & $0.0[0.0,0.0]$ \\
\hline 4 Staff time & 2 & & $\begin{array}{l}\text { Mean Difference (IV, Fixed, } \\
95 \% \mathrm{CI} \text { ) }\end{array}$ & $\begin{array}{l}\text { Totals not select- } \\
\text { ed }\end{array}$ \\
\hline $\begin{array}{l}\text { 4.1 Skin cleanser/moisturiser (A) versus } \\
\text { soap and water (B) (urine) }\end{array}$ & 1 & & $\begin{array}{l}\text { Mean Difference (IV, Fixed, } \\
95 \% \mathrm{CI} \text { ) }\end{array}$ & $0.0[0.0,0.0]$ \\
\hline $\begin{array}{l}\text { 4.2 Skin cleanser/moisturiser (A) versus } \\
\text { soap and water (B) (urine and stool) }\end{array}$ & 1 & & $\begin{array}{l}\text { Mean Difference (IV, Fixed, } \\
95 \% \mathrm{CI} \text { ) }\end{array}$ & $0.0[0.0,0.0]$ \\
\hline $\begin{array}{l}4.3 \text { No-rinse skin cleanser and a skin } \\
\text { cream (A) versus soap and water and a lo- } \\
\text { tion (B) }\end{array}$ & 1 & & $\begin{array}{l}\text { Mean Difference (IV, Fixed, } \\
95 \% \mathrm{CI} \text { ) }\end{array}$ & $0.0[0.0,0.0]$ \\
\hline $\begin{array}{l}5 \text { Number of participants with IAD com- } \\
\text { pletely healed }\end{array}$ & 1 & & $\begin{array}{l}\text { Risk Ratio (M-H, Fixed, } \\
95 \% \mathrm{Cl})\end{array}$ & $\begin{array}{l}\text { Totals not select- } \\
\text { ed }\end{array}$ \\
\hline 5.1 Desitin (A) versus Calmoseptine (B) & 1 & & $\begin{array}{l}\text { Risk Ratio (M-H, Fixed, } \\
95 \% \mathrm{Cl})\end{array}$ & $0.0[0.0,0.0]$ \\
\hline 6 IAD severity & 3 & & $\begin{array}{l}\text { Mean Difference (IV, Fixed, } \\
95 \% \mathrm{CI})\end{array}$ & $\begin{array}{l}\text { Totals not select- } \\
\text { ed }\end{array}$ \\
\hline $\begin{array}{l}6.1 \text { Sudocrem }(A) \text { versus zinc oxide cream } \\
\text { (B) }\end{array}$ & 1 & & $\begin{array}{l}\text { Mean Difference (IV, Fixed, } \\
95 \% \mathrm{CI} \text { ) }\end{array}$ & $0.0[0.0,0.0]$ \\
\hline $\begin{array}{l}6.2 \text { No-rinse skin cleanser and skin cream } \\
\text { (A) versus soap and water and lotion (B) }\end{array}$ & 1 & & $\begin{array}{l}\text { Mean Difference (IV, Fixed, } \\
95 \% \mathrm{CI} \text { ) }\end{array}$ & $0.0[0.0,0.0]$ \\
\hline $\begin{array}{l}6.3 \text { Zinc oxide cream }(A) \text { versus petrola- } \\
\text { tum ointment }(B)\end{array}$ & 1 & & $\begin{array}{l}\text { Mean Difference (IV, Fixed, } \\
95 \% \mathrm{CI} \text { ) }\end{array}$ & $0.0[0.0,0.0]$ \\
\hline $\begin{array}{l}\text { 6.4 Zinc oxide cream (A) versus film-form- } \\
\text { ing skin product (B) }\end{array}$ & 1 & & $\begin{array}{l}\text { Mean Difference (IV, Fixed, } \\
95 \% \mathrm{CI})\end{array}$ & $0.0[0.0,0.0]$ \\
\hline
\end{tabular}




\begin{tabular}{lllll}
\hline Outcome or subgroup title & No. of studies & $\begin{array}{l}\text { No. of partici- } \\
\text { pants }\end{array}$ & Statistical method & Effect size \\
\hline $\begin{array}{l}\text { 6.5 Petrolatum ointment (A) versus film- } \\
\text { forming skin product (B) }\end{array}$ & 1 & & $\begin{array}{l}\text { Mean Difference (IV, Fixed, } \\
95 \% \mathrm{Cl})\end{array}$ & $0.0[0.0,0.0]$ \\
\hline
\end{tabular}

Analysis 1.1. Comparison 1 Any topical skin care product versus another topical skin care product, Outcome 1 Number of participants with IAD (residual, i.e. not healed).

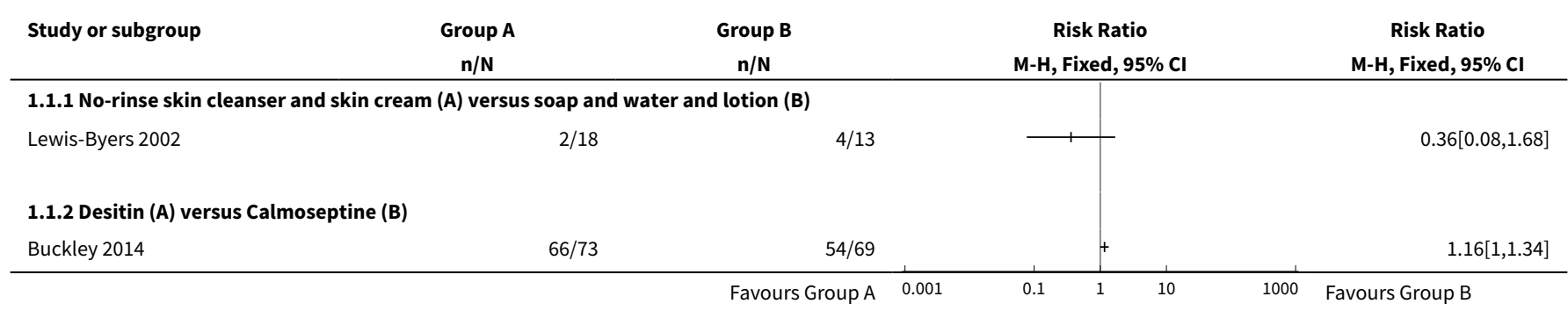

Analysis 1.2. Comparison 1 Any topical skin care product versus another topical skin care product, Outcome 2 Number of participants with IAD (new).

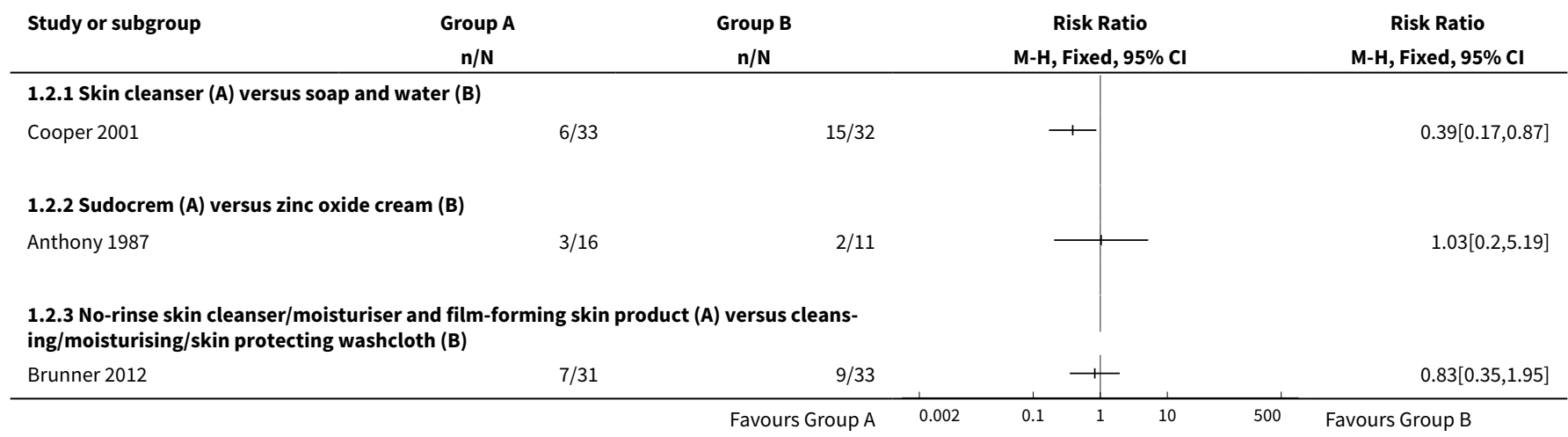

Analysis 1.3. Comparison 1 Any topical skin care product versus another topical skin care product, Outcome 3 Surface affected by IAD (measurement of size of lesion).

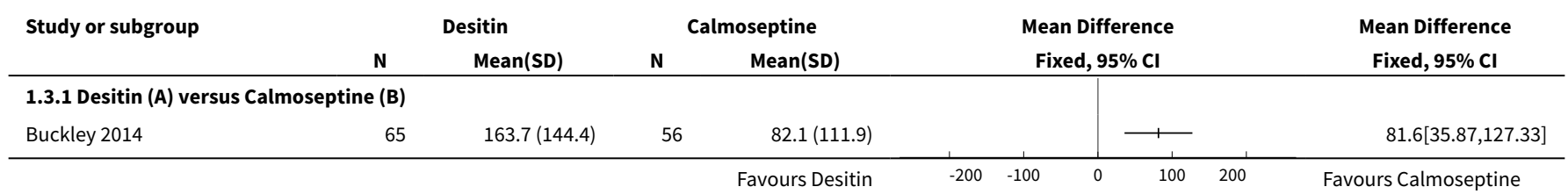


Analysis 1.4. Comparison 1 Any topical skin care product versus another topical skin care product, Outcome 4 Staff time.

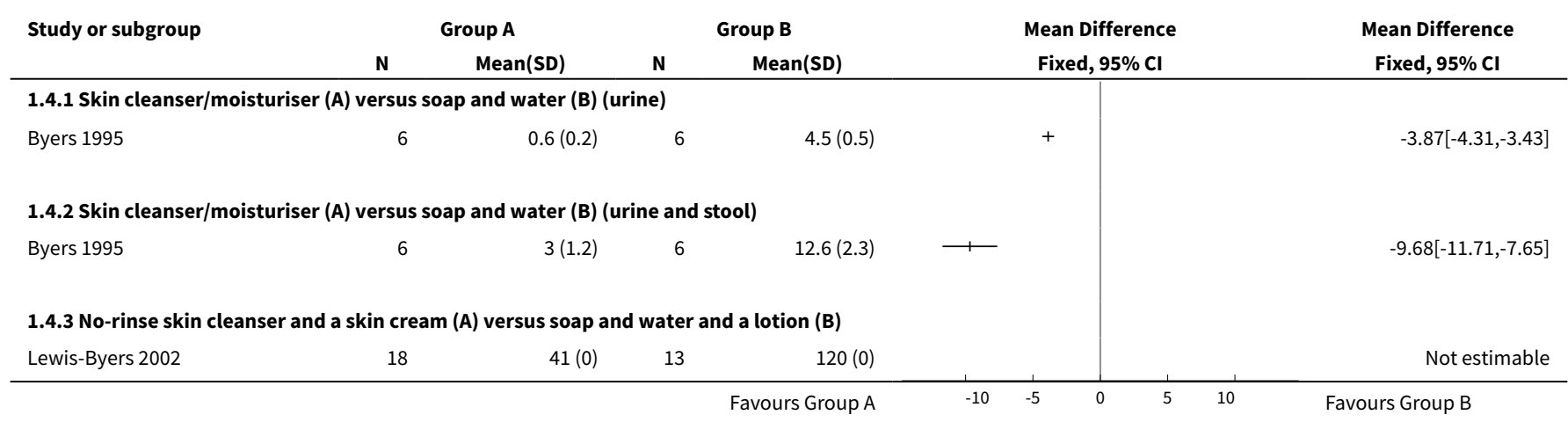

Analysis 1.5. Comparison 1 Any topical skin care product versus another topical skin care product, Outcome 5 Number of participants with IAD completely healed.

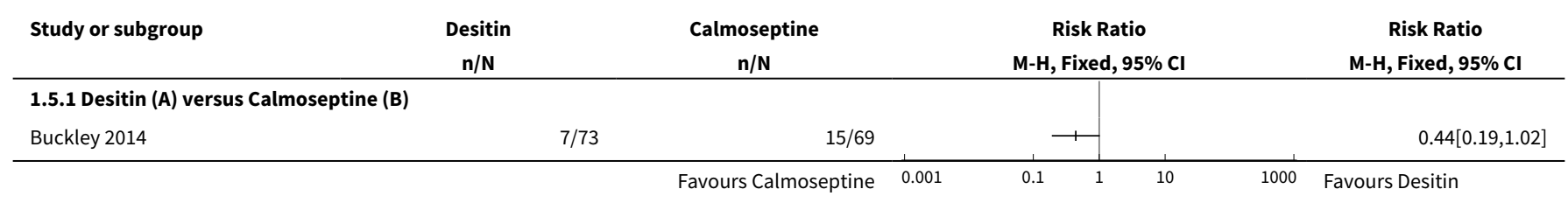

\section{Analysis 1.6. Comparison 1 Any topical skin care product versus another topical skin care product, Outcome 6 IAD severity.}

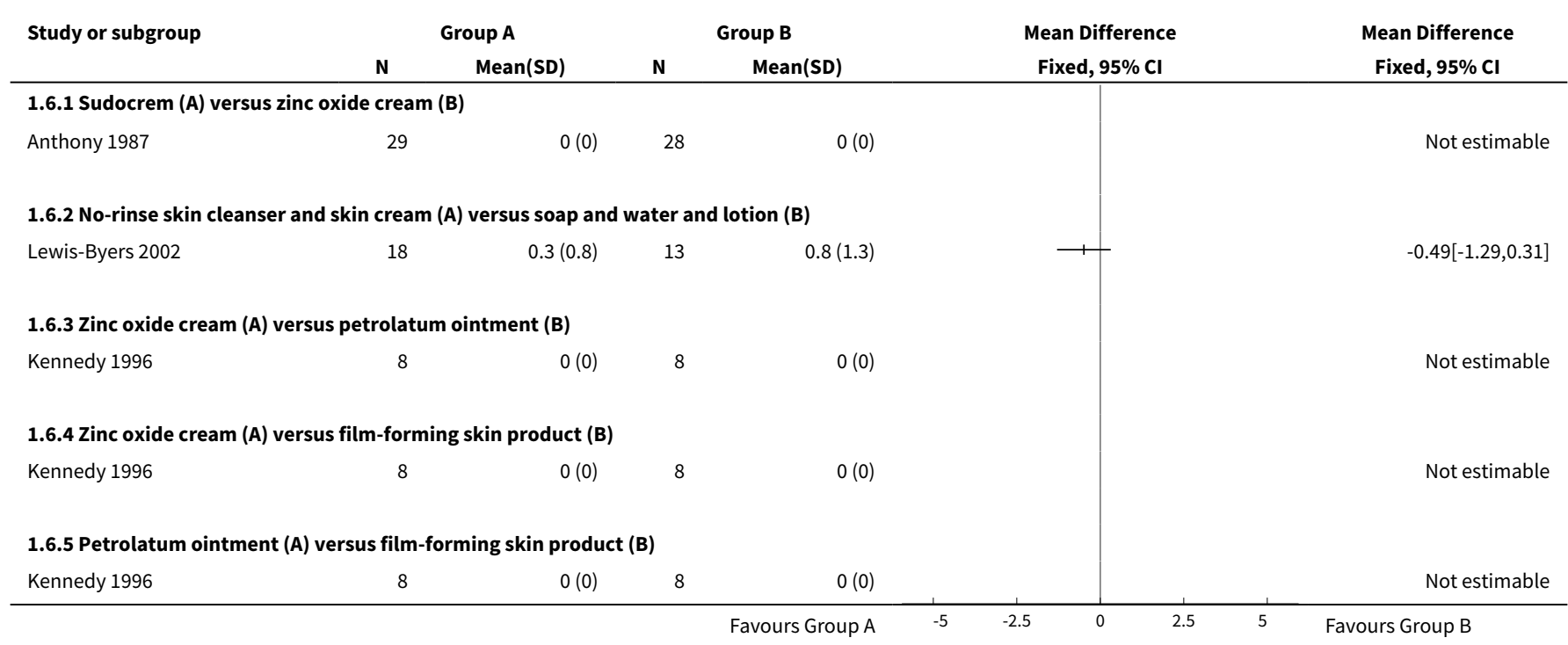


Comparison 2. Any skin care procedure (method or frequency of application) versus any unstructured skin care procedure

\begin{tabular}{|c|c|c|c|c|}
\hline Outcome or subgroup title & No. of studies & $\begin{array}{l}\text { No. of partici- } \\
\text { pants }\end{array}$ & Statistical method & Effect size \\
\hline $\begin{array}{l}1 \text { Number of participants with IAD (residual, } \\
\text { i.e. not healed) }\end{array}$ & 1 & & $\begin{array}{l}\text { Risk Ratio (M-H, Fixed, } \\
95 \% \mathrm{Cl})\end{array}$ & $\begin{array}{l}\text { Totals not select- } \\
\text { ed }\end{array}$ \\
\hline $\begin{array}{l}1.1 \text { Washcloth with cleansing, moisturising, } \\
\text { and protecting properties (A) versus water } \\
\text { and pH neutral soap (B) }\end{array}$ & 1 & & $\begin{array}{l}\text { Risk Ratio (M-H, Fixed, } \\
95 \% \mathrm{Cl})\end{array}$ & $0.0[0.0,0.0]$ \\
\hline 2 IAD Severity & 1 & & $\begin{array}{l}\text { Mean Difference (IV, } \\
\text { Fixed, } 95 \% \mathrm{CI} \text { ) }\end{array}$ & $\begin{array}{l}\text { Totals not select- } \\
\text { ed }\end{array}$ \\
\hline $\begin{array}{l}\text { 2.1 Washcloth with cleansing, moisturising, } \\
\text { and protecting properties (A) versus water } \\
\text { and } \mathrm{pH} \text { neutral soap (B) }\end{array}$ & 1 & & $\begin{array}{l}\text { Mean Difference (IV, } \\
\text { Fixed, } 95 \% \mathrm{Cl} \text { ) }\end{array}$ & $0.0[0.0,0.0]$ \\
\hline
\end{tabular}

Analysis 2.1. Comparison 2 Any skin care procedure (method or frequency of application) versus any unstructured skin care procedure, Outcome 1 Number of participants with IAD (residual, i.e. not healed).

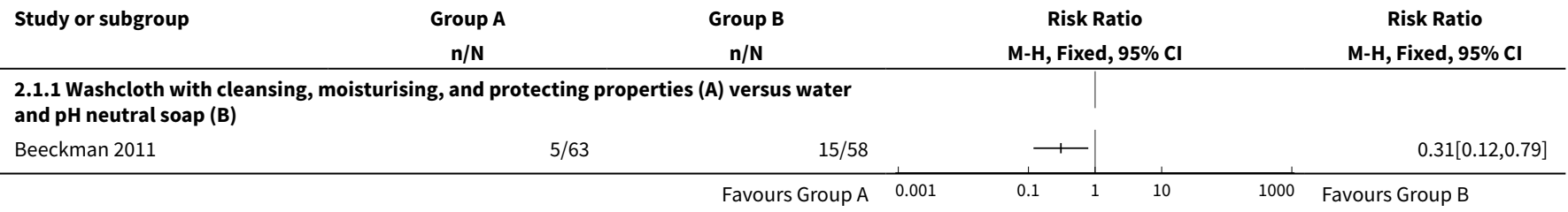

Analysis 2.2. Comparison 2 Any skin care procedure (method or frequency of application) versus any unstructured skin care procedure, Outcome 2 IAD Severity.

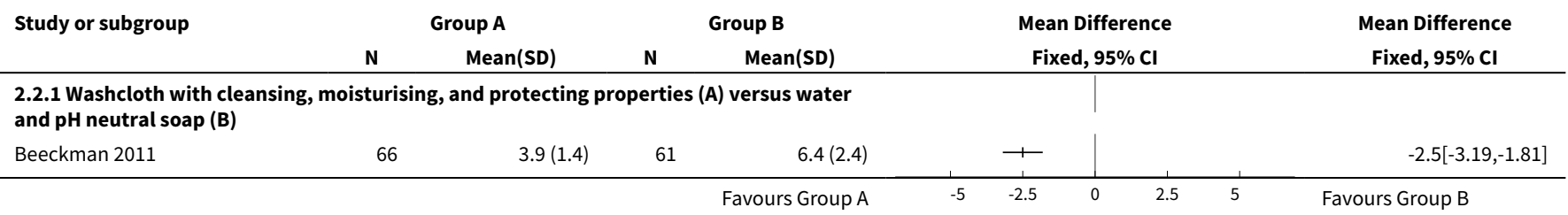

\section{A P P E N DICES}

\section{Appendix 1. Cochrane Incontinence Group Speciailsed Register search strategy}

We used the following terms to search the Cochrane Incontinence Group Specialised Register:

((\{DESIGN.CCT $\left.{ }^{\star}\right\}$ OR \{DESIGN.RCT* $\left.\}\right)$ AND (\{TOPIC.URINE.INCON.Skin* $\}$ OR \{TOPIC.FAECAL.INCON.Skin $\left.\left.\left.{ }^{\star}\right\}\right)\right)$

All searches were of the keyword field of Reference Manager 2012. The date of the last search was 28 September 2016. 


\section{Appendix 2. CENTRAL, MEDLINE and MEDLINE In-Process search strategy}

Cochrane Central Register of Controlled Trials April 2015, Ovid MEDLINE(R) 1946 to May Week 3 2015, Ovid MEDLINE(R) In-Process \& Other Non-Indexed Citations 26 May 2015 on OvidSP were searched on 27 May 2015 using the following search:

1. controlled clinical trial.pt.

2. randomized controlled trial.pt.

3. randomized controlled trials/

4. random allocation/

5. double blind method/

6. single blind method/

7. clinical trial.pt.

8. exp clinical trial/

9. placebos/

10. placebo\$.tw.

11. random\$.tw.

12. research design/

13. volunteer\$.tw.

14. (clin\$ adj25 trial\$).tw.

15. ((singl\$ or doubl\$ or trebl\$ or tripl\$) adj25 (blind\$ or mask\$)).tw.

16. factorial.tw.

17. cross-over studies/

18. crossover.tw.

19. latin square.tw.

20. (balance $\$$ adj2 block\$).tw.

21. trial.ti.

22. (animals not humans).sh.

23. or/1-21

24. 23 not 22

25. (incontinen ${ }^{\star}$ adj25 dermatitis).tw.

26. (incontinen* adj25 skin).tw.

27. exp dermatological agents/ and Pressure Ulcer/

28. (incontinen ${ }^{\star}$ adj2 lesion $\left.{ }^{\star}\right) . t w$.

29. (moisture adj2 lesion*).tw.

30. (macerat* adj2 skin*).tw.

31. (perine* adj2 dermatitis).tw.

32. Diaper Rash/ 
33. 25 or 26 or 27 or 28 or 29 or 30 or 31 or 32

\subsection{3 and 24}

35. dermatitis/ or dermatitis, contact/ or dermatitis, irritant/ or diaper rash/ or erythema/

36. Pressure Ulcer/

37. skin integrity.tw.

38. skin inflam*.tw.

39. (skin $\operatorname{adj} 2$ loss $\left.{ }^{\star}\right) . t w$.

40. (skin adj2 red $\left.^{\star}\right)$. tw.

41. (skin adj2 blister $\left.{ }^{\star}\right)$.tw.

42. (skin adj2 bull*).tw.

43. (skin adj2 perine*).tw.

44. erythema*.tw.

45. (skin $\operatorname{adj} 2\left(\operatorname{erod}^{\star}\right.$ or erosion*)).tw.

46. (skin adj2 barrier $\left.{ }^{\star}\right) . t w$.

47. secondary skin infect*.tw.

48. (cutaneous adj2 loss $\left.^{\star}\right)$.tw.

49. (cutaneous adj2 (red $^{\star}$ or blister ${ }^{\star}$ or bull ${ }^{\star}$ or perine ${ }^{\star}$ or barrier $^{\star}$ or loss ${ }^{\star}$ or inflam ${ }^{\star}$ or integrity)).tw.

50. (epiderm* adj2 loss $\left.{ }^{\star}\right)$. tw.

51. (epiderm ${ }^{\star}$ adj2 (red ${ }^{\star}$ or blister ${ }^{\star}$ or bull ${ }^{\star}$ or perine ${ }^{\star}$ or barrier ${ }^{\star}$ or loss ${ }^{\star}$ or inflam ${ }^{\star}$ or integrity)).tw.

52. (skin $\operatorname{adj} 2$ rash $\left.^{\star}\right)$.tw.

53. (rash* adj2 (epiderm* or cutaneous or cuticle)).tw.

54. (dermatit* adj2 (contact or irrit $\left.{ }^{\star}\right)$ ).tw.

55. (skin adj2 damag $\left.{ }^{\star}\right)$.tw.

56. (skin adj2 lesion^).tw.

57. Perineum/

58. perirect ${ }^{\star}$. tw.

59. perianal.tw.

60. buttocks/ or thigh/

61. intergluteal.tw.

62. perigenital.tw.

63. perine ${ }^{\star}$.tw.

64. inguinal.tw.

65. Intertrigo/

66. (buttock* or thigh ${ }^{\star}$ ).tw.

67 . genital ${ }^{*}$. tw. 
68. intertrig*.tw.

69. genitalia/ or genitalia, female/ or vulva/ or genitalia, male/ or scrotum/

70. vulva*.tw.

71. scrot* ${ }^{\star} . \mathrm{tw}$.

72. (labium or labia).tw.

73. heat rash*.tw.

74. (heat adj2 rash*).tw.

75. Dermatitis, Allergic Contact/

76. ((diaper ${ }^{\star}$ or napkin ${ }^{\star}$ or nappy or nappies or perine $\left.{ }^{\star}\right)$ adj2 (dermat* or erythema $^{\star}$ or rash $^{\star}$ or wet $\left.\left.^{\star}\right)\right)$.tw.

77. (moist ${ }^{\star}$ adj2 (sore or ulcer $^{\star}$ or damag $^{\star}$ or wound ${ }^{\star}$ or injur ${ }^{\star}$ or lesion ${ }^{\star}$ or skin)).tw.

78. ((decubitus or pressure or bed) adj2 (sore* or ulcer $\left.\left.^{\star}\right)\right)$.tw.

79. bedsore*.tw.

80. or/35-79

81.24 and 80

82. exp Skin Care/

83. hygiene/

84. dermatologic agents/ or zinc oxide/ or emollients/ or mineral oil/ or petrolatum/ or simethicone/

85. surface-active agents/ or soaps/

86. Ointments/

87. exp Detergents/

88. pharmaceutic aids/ or ointment bases/ or petrolatum/ or pharmaceutical vehicles/ or propylene glycol/

89. pharmaceutical vehicles/ or propylene glycol/ or excipients/ or octoxynol/ or poloxamer/ or polysorbates/ or tragacanth/ or tromethamine/

90. skincar*.tw.

91. skin care.tw.

92. (skin adj2 (regime $^{\star}$ or protocol ${ }^{\star}$ or program $\left.\left.{ }^{\star}\right)\right)$. tw.

93. (skin adj2 clean*).tw.

94. (skin adj2 moistur ${ }^{\star}$.tw.

95. (skin adj2 protect $\left.{ }^{\star}\right) . t w$.

96. (moisture adj2 barrier $\left.{ }^{\star}\right)$.tw.

97. (skin adj2 (product or products)).tw.

98. (perine* adj2 clean*).tw.

99. washcloth*.tw.

100. barrier cloth ${ }^{\star}$. tw.

101. (wash adj2 cloth*).tw. 
102. exp Oils/

103. (skin adj2 (health or integrity or restor ${ }^{\star}$ or maintain $\left.{ }^{\star}\right)$ ).tw.

104. (skin adj2 manag*).tw.

105. Baths/

106. (skin adj2 wash`).tw.

107. shower*.tw.

108. or/82-107

109. 81 and 108

110. 34 or 109

111. remove duplicates from 110

112. cochrane incontinence group.gc.

113. 111 not 112

\section{Appendix 3. CINAHL search strategy}

CINAHL (on EBSCO) covering from inception (December 1981) to 20150527 (entry date) was searched on 28 May 2015 using the following search strategy:

\begin{tabular}{|c|c|}
\hline$\#$ & Query \\
\hline S112 & S27 OR S41 OR S111 \\
\hline S111 & S23 AND S83 AND S110 \\
\hline S110 & $\begin{array}{l}\text { S } 84 \text { OR S } 85 \text { OR S } 86 \text { OR S } 87 \text { OR S } 88 \text { OR S89 OR S90 OR S91 OR S92 OR S93 OR S94 OR S95 OR S96 OR } \\
\text { S } 97 \text { OR S98 OR S99 OR S100 OR S101 OR S102 OR S103 OR S104 OR S105 OR S106 OR S107 OR S108 } \\
\text { OR S109 }\end{array}$ \\
\hline S109 & $A B$ shower* \\
\hline S108 & TI shower* \\
\hline S107 & $\begin{array}{l}\text { (MH "Bathing and Baths") OR (MH "Self-Care Assistance: Bathing-Hygiene (lowa NIC)") OR (MH } \\
\text { "Bathing-Hygiene Self Care Deficit (NANDA)") OR (MH "Bathing-Hygiene Deficit (Saba CCC)") OR } \\
\text { (MH "Self-Care: Bathing (lowa NOC)") OR (MH "Bathing (lowa NIC)") }\end{array}$ \\
\hline S106 & (MH "Oils+") \\
\hline S105 & AB wash N2 cloth* \\
\hline S104 & TI wash N2 cloth* \\
\hline S103 & AB barrier N2 cloth* \\
\hline S102 & TI barrier N2 cloth* \\
\hline S101 & AB washcloth* \\
\hline S100 & TI washcloth* \\
\hline
\end{tabular}




\begin{tabular}{|c|c|}
\hline S99 & AB perine ${ }^{\star} \mathrm{N} 2$ clean $^{\star}$ \\
\hline S98 & TI perine* N2 clean* \\
\hline S97 & AB moisture N2 barrier ${ }^{\star}$ \\
\hline S96 & TI moisture N2 barrier* \\
\hline S95 & $\begin{array}{l}\text { AB skin N2 regime* OR skin N2 protocol* OR skin N2 program* OR skin N2 clean* OR skin N2 } \\
\text { moistur }{ }^{\star} \text { OR skin N2 protect* OR skin N2 product OR skin N2 products OR skin N2 health OR skin N2 } \\
\text { integrity OR skin N2 restor* OR skin N2 maintain* OR skin N2 manag* OR skin N2 wash* }\end{array}$ \\
\hline S94 & $\begin{array}{l}\text { TI skin N2 regime* OR skin N2 protocol* OR skin N2 program* OR skin N2 clean* OR skin N2 } \\
\text { moistur* OR skin N2 protect* OR skin N2 product OR skin N2 products OR skin N2 health OR skin N2 } \\
\text { integrity OR skin N2 restor* OR skin N2 maintain* OR skin N2 manag* OR skin N2 wash* }\end{array}$ \\
\hline S93 & AB skin care \\
\hline S92 & TI skin care \\
\hline S91 & AB skincare \\
\hline S90 & TI skincare \\
\hline S89 & (MH "Propylene Glycols+") \\
\hline S88 & (MH "Creams") OR (MH "Ointments") OR (MH "Liniments") \\
\hline S87 & (MH "Surface-Active Agents+") \\
\hline
\end{tabular}

(MH "Hygiene") OR (MH "Self-Care Assistance: Bathing-Hygiene (lowa NIC)") OR (MH "Bathing-Hygiene Self Care Deficit (NANDA)") OR (MH "Bathing-Hygiene Deficit (Saba CCC)") OR (MH "Self-Care: Hygiene (lowa NOC)")

\begin{tabular}{ll}
\hline S84 & (MH "Skin Care") OR (MH "Skin Care (Saba CCC)") OR (MH "Skin Care: Topical Treatments (Iowa \\
& NIC)") OR (MH "Perineal Care") \\
\hline S83 & S42 OR S43 OR S44 OR S45 OR S46 OR S47 OR S48 OR S49 OR S50 OR S51 OR S52 OR S53 OR S54 OR \\
& S55 OR S56 OR S57 OR S58 OR S59 OR S60 OR S61 OR S62 OR S63 OR S64 OR S65 OR S66 OR S67 OR \\
& S68 OR S69 OR S70 OR S71 OR S72 OR S73 OR S74 OR S75 OR S76 OR S77 OR S78 OR S79 OR S80 OR \\
& S81 OR S82 \\
\hline S82 & AB bed N2 sore* OR bed N2 ulcer* \\
\hline S81 & TI bed N2 sore* OR bed N2 ulcer \\
\hline S80 & AB pressure N2 sore* OR pressure N2 ulcer* \\
\hline S79 & TI pressure N2 sore* OR pressure N2 ulcer* \\
\hline S78 & AB decubitus N2 sore* OR decubitus N2 ulcer* \\
\hline S77 & TI decubitus N2 sore* OR decubitus N2 ulcer* \\
\hline
\end{tabular}


S76 AB moist ${ }^{\star}$ N2 sore* OR moist ${ }^{\star}$ N2 ulcer* OR moist ${ }^{\star}$ N2 damag* OR moist ${ }^{\star}$ N2 wound* OR moist* N2 injur* OR moist* N2 lesion* OR moist* N2 skin

S75 TI moist ${ }^{\star}$ N2 sore $^{\star}$ OR moist ${ }^{\star}$ N2 ulcer* OR moist ${ }^{\star}$ N2 damag* OR moist ${ }^{\star}$ N2 wound* OR moist* N2 injur* OR moist* N2 lesion* OR moist* N2 skin

\begin{tabular}{|c|c|}
\hline S74 & AB perine ${ }^{\star} \mathrm{N} 2$ rash $^{\star}$ OR perine ${ }^{\star} \mathrm{N} 2$ wet $^{\star}$ \\
\hline S73 & TI perine ${ }^{\star} \mathrm{N} 2$ rash $^{\star}$ OR perine ${ }^{\star} \mathrm{N} 2$ wet $^{\star}$ \\
\hline S72 & AB nappies N2 dermatit* OR nappies N2 rash* OR nappies N2 wet ${ }^{\star}$ \\
\hline S71 & TI nappies N2 dermatit* OR nappies N2 rash* OR nappies N2 wet* \\
\hline S70 & AB nappy N2 dermatit* OR nappy N2 rash* OR nappy N2 wet* \\
\hline S69 & TI nappy N2 dermatit* OR nappy N2 rash* OR nappy N2 wet* \\
\hline S68 & AB napkin* N2 dermatit* OR napkin* N2 rash* OR napkin* N2 wet* \\
\hline S67 & TI napkin* N2 dermatit* OR napkin* N2 rash* OR napkin* N2 wet ${ }^{\star}$ \\
\hline S66 & AB diaper* N2 dermatit* OR diaper* N2 rash ${ }^{\star}$ OR diaper N2 wet* \\
\hline S65 & 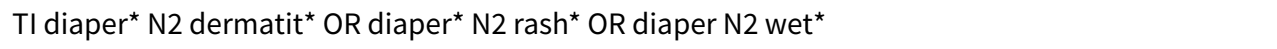 \\
\hline S64 & $A B$ bedsore* \\
\hline S63 & Tl bedsore ${ }^{\star}$ \\
\hline S62 & $\mathrm{AB}$ rash* $\mathrm{N} 2$ heat \\
\hline S61 & TI rash* N2 heat \\
\hline S60 & AB dermatit* $N 2$ contact OR dermatit* $N 2$ contact \\
\hline S59 & TI dermatit* N2 contact OR dermatit* N2 contact \\
\hline S58 & AB rash* N2 cuticle \\
\hline S57 & TI rash* N2 cuticle \\
\hline S56 & 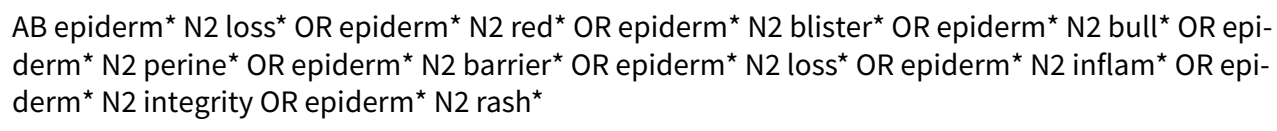 \\
\hline S55 & 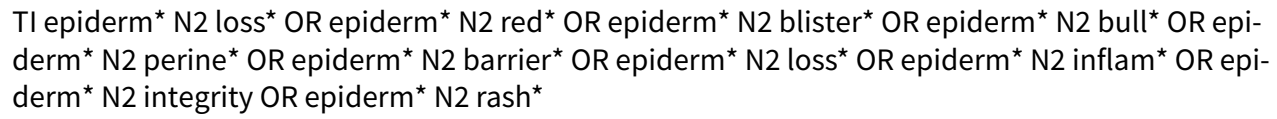 \\
\hline
\end{tabular}
cutaneous N2 perine ${ }^{\star}$ OR cutaneous N2 barrier* OR cutaneous N2 loss* OR cutaneous N2 inflam * OR cutaneous N2 integrity OR cutaneous N2 rash* cutaneous N2 perine* OR cutaneous N2 barrier $^{\star}$ OR cutaneous N2 loss* OR cutaneous N2 inflam* OR cutaneous N2 integrity OR cutaneous N2 rash* 


\begin{tabular}{|c|c|}
\hline S52 & AB erythema* \\
\hline S51 & TI erythema* \\
\hline S50 & $\begin{array}{l}\text { AB skin N2 loss* OR skin N2 red* OR skin N2 blister }{ }^{\star} \text { OR skin N2 bull* OR skin N2 perine* OR skin N2 } \\
\text { erod }^{\star} \text { OR skin N2 erosion* OR skin N2 barrier }{ }^{\star} \text { OR skin N2 rash OR skin N2 damag* OR skin N2 le- } \\
\text { sion }^{\star}\end{array}$ \\
\hline S49 & $\begin{array}{l}\text { TI skin N2 loss* OR skin N2 red* OR skin N2 blister* OR skin N2 bull* OR skin N2 perine* OR skin N2 } \\
\text { erod* OR skin N2 erosion* OR skin N2 barrier* OR skin N2 rash^ OR skin N2 damag* OR skin N2 le- } \\
\text { sion* }\end{array}$ \\
\hline S48 & AB skin N2 inflam* \\
\hline S47 & TI skin N2 inflam* \\
\hline S46 & AB skin N2 integrity \\
\hline S45 & TI skin N2 integrity \\
\hline S44 & AB pressure N2 ulcer \\
\hline S43 & TI pressure N2 ulcer \\
\hline
\end{tabular}

S42 (MH "Pressure Ulcer") OR (MH "Pressure Ulcer Stage 4 Care (Saba CCC)") OR (MH "Pressure Ulcer Stage 3 Care (Saba CCC)") OR (MH "Pressure Ulcer Stage 2 Care (Saba CCC)") OR (MH "Pressure UIcer Stage 1 Care (Saba CCC)") OR (MH "Pressure Ulcer Care (Saba CCC)") OR (MH "Pressure Ulcer Prevention (lowa NIC)") OR (MH "Pressure Ulcer Care (lowa NIC)")

\begin{tabular}{|c|c|}
\hline S41 & S23 AND S40 \\
\hline S40 & S28 OR S29 OR S30 OR S31 OR S32 OR S33 OR S34 OR S 35 OR S36 OR S37 OR S38 OR S39 \\
\hline S39 & AB perine* N2 dermatitis* \\
\hline S38 & Tl perine* N2 dermatitis* \\
\hline S37 & AB macerat* $N 2$ skin $^{*}$ \\
\hline S36 & TI macerat* N2 skin* \\
\hline S35 & AB moisture N2 lesion* \\
\hline S34 & TI moisture N2 lesion* \\
\hline S33 & $A B$ incontinen* $N 2$ lesion* \\
\hline S32 & Tl incontinen* $\mathrm{N} 2$ lesion* \\
\hline S31 & $A B$ incontinen* $N 25$ skin \\
\hline S30 & Tl incontinen* N25 skin \\
\hline S29 & AB incontinen* N25 dermatitis \\
\hline $\mathrm{S} 28$ & $\mathrm{Tl}$ incontinen ${ }^{\star} \mathrm{N} 25$ dermatitis \\
\hline
\end{tabular}




\begin{tabular}{ll} 
S27 & S23 AND S26 \\
\hline S26 & S24 OR S25 \\
\hline S25 & (MH "Diaper Rash") \\
\hline S24 & (MH "Dermatitis, Perineal") \\
\hline S23 & S1 or S2 or S3 or S4 or S5 or S6 or S7 or S8 or S9 or S10 or S11 or S12 or S13 or S14 or S15 or S16 or \\
& S17 or S18 or S19 or S20 or S21 or S22
\end{tabular}

TI ( singl ${ }^{\star}$ N25 blind* OR singl ${ }^{\star}$ N25 mask* OR doubl* N25 blind* or doubl* N25 mask* OR trebl* N25 blind $^{\star}$ OR trebl ${ }^{\star}$ N25 mask ${ }^{\star}$ OR tripl ${ }^{\star}$ N25 blind ${ }^{\star}$ OR tripl* N25 mask ${ }^{\star}$ ) or AB ( singl ${ }^{\star}$ N25 blind ${ }^{\star}$ OR singl ${ }^{\star}$ N25 mask OR doubl $^{*}$ N25 blind ${ }^{*}$ or doubl ${ }^{*}$ N25 mask ${ }^{\star}$ OR trebl ${ }^{\star}$ N25 blind ${ }^{\star}$ OR trebl ${ }^{*}$ N25 mask $^{\star}$ OR tripl ${ }^{\star}$ N25 blind* OR tripl* N25 mask* )

\begin{tabular}{|c|c|}
\hline $\mathrm{S} 21$ & (MH "Comparative Studies") \\
\hline S20 & (MH "Clinical Research+") \\
\hline S19 & (MH "Static Group Comparison") \\
\hline S18 & (MH "Quantitative Studies") \\
\hline S17 & (MH "Crossover Design") or (MH "Solomon Four-Group Design") \\
\hline S16 & (MH "Factorial Design") \\
\hline S15 & (MH "Community Trials") \\
\hline S14 & (MH "Random Sample") \\
\hline S13 & TI balance* N2 block* or AB balance* N2 block ${ }^{\star}$ \\
\hline S12 & TI "latin square" or AB "latin square" \\
\hline S11 & TI factorial or AB factorial \\
\hline S10 & TI clin* N25 trial* or AB clin* N25 trial* \\
\hline S9 & (MH "Study Design") \\
\hline S8 & $\left(\mathrm{AB}\right.$ random $\left.{ }^{\star}\right) \mathrm{OR}(\mathrm{TI}$ random*$)$ \\
\hline S7 & (AB placebo*) OR (TI placebo*) \\
\hline S6 & (MH "Placebos") \\
\hline S5 & (PT Clinical Trial) OR (PT "randomized controlled trial") \\
\hline S4 & (MH "Clinical Trials+") \\
\hline S3 & MH (random assignment) OR (crossover design) \\
\hline S2 & cross-over \\
\hline
\end{tabular}




\section{Appendix 4. Web of Science (WoS) search strategy}

Web of Science (on Web of Knowledge) - covering from inception of each component database to the most recent records available - was searched on 28 May 2015 using the search strategy given below. The search was limited to the WoS Core Collection

\begin{tabular}{|c|c|}
\hline Set & \\
\hline \multirow[t]{4}{*}{ \#42 } & \#40 OR \#22 \\
\hline & Refined by: Databases: ( WOS ) \\
\hline & Timespan=All years \\
\hline & Search language $=$ Auto \\
\hline \multirow[t]{3}{*}{ \#41 } & \#40 OR \#22 \\
\hline & Timespan=All years \\
\hline & Search language $=$ Auto \\
\hline \multirow[t]{2}{*}{ \#40 } & \#39 AND \#33 AND \#5 \\
\hline & DocType=All document types; Language=All languages; \\
\hline \multirow[t]{2}{*}{ \#39 } & \#38 OR \#37 OR \#36 OR \#35 OR \#34 \\
\hline & DocType=All document types; Language=All languages; \\
\hline \#38 & $\begin{array}{l}\text { TOPIC: (Oils or bath* OR shower* OR hygiene OR zinc oxide OR emollients OR mineral oil OR petro- } \\
\text { latum OR simethicone OR soap }{ }^{\star} \text { OR ointment }{ }^{\star} \text { OR detergent }{ }^{\star} \text { ) } \\
\text { DocType=All document types; Language=All languages; }\end{array}$ \\
\hline \multirow[t]{2}{*}{ \#37 } & TOPIC: ((wash OR barrier) NEAR/2 cloth) \\
\hline & DocType=All document types; Language=All languages; \\
\hline \multirow[t]{2}{*}{ \#36 } & TOPIC: (washcloth^ OR skincar) \\
\hline & DocType=All document types; Language=All languages; \\
\hline \multirow[t]{2}{*}{ \#35 } & $\begin{array}{l}\text { TOPIC: ((skin NEAR/2 (care OR regime* OR protocol* OR program* OR clean* OR moistur }{ }^{\star} \text { OR pro- } \\
\text { tect }^{\star} \text { OR product OR products OR health OR integrity OR restor }{ }^{\star} \text { OR maintain* OR manag }{ }^{\star} \text { OR } \\
\left.\left.\text { wash }^{\star}\right)\right) \text { ) }\end{array}$ \\
\hline & DocType=All document types; Language=All languages; \\
\hline \multirow[t]{2}{*}{ \#34 } & TOPIC: (perine* NEAR/2 clean*) \\
\hline & DocType=All document types; Language=All languages; \\
\hline \multirow[t]{2}{*}{ \#33 } & \#32 OR \#31 OR \#30 OR \#29 OR \#28 OR \#27 OR \#26 OR \#25 OR \#24 OR \#23 \\
\hline & DocType=All document types; Language=All languages; \\
\hline \multirow[t]{2}{*}{ \#32 } & TOPIC: (bedsore*) \\
\hline & DocType=All document types; Language=All languages; \\
\hline \multirow[t]{2}{*}{ \#31 } & TOPIC: ((decubitus OR pressurre OR bed) NEAR/2 (sore* OR ulcer)) \\
\hline & DocType=All document types; Language=All languages; \\
\hline
\end{tabular}


(Continued)

\#30 TOPIC: (moist* NEAR/2 (sore* OR ulcer OR damag* OR wound* OR injur OR lesion* or skin)) DocType=All document types; Language=All languages;

\begin{tabular}{|c|c|}
\hline$\# 29$ & $\begin{array}{l}\left.\text { TOPIC: ((diaper }{ }^{\star} \text { OR napkin* OR nappy OR nappies OR perine }{ }^{\star}\right) \text { NEAR/2 (dermat* OR erythema* OR } \\
\left.\text { rash }^{\star} \text { OR wet }{ }^{\star}\right) \text { ) } \\
\text { DocType=All document types; Language=All languages; }\end{array}$ \\
\hline \#28 & $\begin{array}{l}\left.\left.\text { TOPIC: (dermatit* NEAR/2 (contact OR irrit }{ }^{\star}\right)\right) \\
\text { DocType=All document types; Language=All languages; }\end{array}$ \\
\hline$\# 27$ & $\begin{array}{l}\text { TOPIC: (rash* NEAR/2 (epiderm* OR cutaneous OR cuticle)) } \\
\text { DocType=All document types; Language=All languages; }\end{array}$ \\
\hline$\# 26$ & $\begin{array}{l}\text { TOPIC: (erythema*) } \\
\text { DocType=All document types; Language=All languages; }\end{array}$ \\
\hline$\# 25$ & 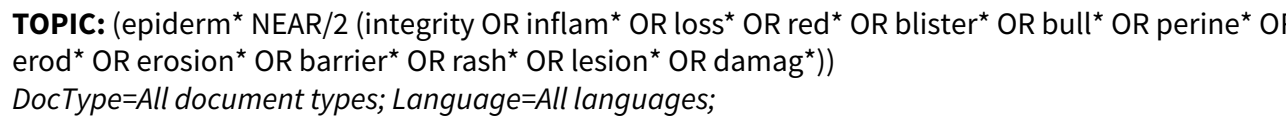 \\
\hline$\# 24$ & 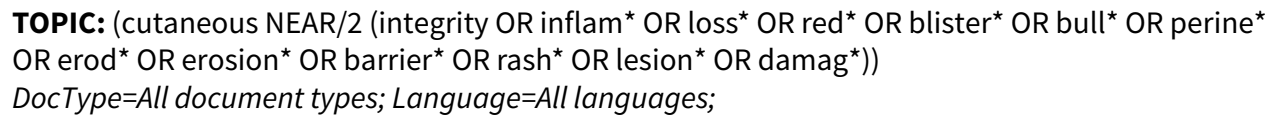 \\
\hline
\end{tabular}

\begin{tabular}{|c|c|}
\hline$\# 23$ & $\begin{array}{l}\text { TOPIC: (skin NEAR/2 (integrity OR inflam* OR loss* OR red* OR blister* OR bull* OR perine* OR } \\
\text { erod* OR erosion* OR barrier* OR rash* OR lesion* OR damag*)) } \\
\text { DocType=All document types; Language=All languages; }\end{array}$ \\
\hline
\end{tabular}

\begin{tabular}{ll}
\hline$\# 22$ & $\# 21$ AND \#5 \\
& DocType=All document types; Language=All languages; \\
\hline$\# 21$ & $\# 20$ OR \#19 OR \#18 OR \#17 OR \#16 OR \#15 OR \#14 OR \#13 OR \#12 OR \#11 OR \#10 OR \#9 OR \#8 OR \#7 \\
& OR \#6 \\
& DocType=All document types; Language=All languages; \\
\hline \multirow{2}{*}{$\# 20$} & TOPIC: (diaper rash) \\
& DocType=All document types; Language=All languages; \\
\hline
\end{tabular}

TOPIC: $\left(\right.$ perine* NEAR/2 dermatitis $\left.{ }^{\star}\right)$
DocType=All document types; Language=All languages;

\begin{tabular}{ll}
\hline$\# 18$ & $\begin{array}{l}\text { TOPIC: }\left(\text { macerat* NEAR/2 skin }{ }^{\star}\right) \\
\text { DocType=All document types; Language=All languages; }\end{array}$ \\
\hline$\# 17$ & $\begin{array}{l}\text { TOPIC: }(\text { moisture NEAR/2 lesion } \\
\text { DocType=All document types; Language=All languages; }\end{array}$ \\
\hline$\# 16$ & TOPIC: (incontinen ${ }^{\star}$ NEAR/2 lesion $\left.{ }^{\star}\right)$ \\
& DocType=All document types; Language=All languages;
\end{tabular}

TOPIC: (dermatological AND (pressure near/2 ulcer $\left.{ }^{\star}\right)$ )
DocType=All document types; Language=All languages;

\begin{tabular}{ll}
\hline$\# 14$ & $\begin{array}{l}\text { TOPIC: }\left(\text { emollient }{ }^{\star} \text { AND decubit }\right. \\
\text { DocType }\end{array}$ \\
\hline$\# 13$ & TOPIC: $\left(\left(\right.\right.$ mineral near $/ 2$ oil $\left.^{\star}\right)$ AND decubit $\left.{ }^{\star}\right)$
\end{tabular}




TOPIC: (petrolatum AND decubit ${ }^{\star}$ )
DocType=All document types; Language=All languages;

\#10 TOPIC: (petrolatum AND (pressure near/2 ulcer $\left.{ }^{\star}\right)$ )
DocType=All document types; Language=All languages;

\#9 TOPIC: ((mineral near/2 oil $\left.{ }^{\star}\right)$ AND (pressure near/2 ulcer $\left.\left.{ }^{\star}\right)\right)$ DocType=All document types; Language=All languages;

TOPIC: (emollient ${ }^{\star}$ AND (pressure near/2 ulcer $\left.\left.^{\star}\right)\right)$
DocType=All document types; Language=All languages;

\begin{tabular}{|c|c|}
\hline$\# 7$ & $\begin{array}{l}\text { TOPIC: (incontinence NEAR/25 skin) } \\
\text { DocType=All document types; Language=All languages; }\end{array}$ \\
\hline \#6 & $\begin{array}{l}\text { TOPIC: (incontinence NEAR/ } 25 \text { dermatitis) } \\
\text { DocType=All document types; Language=All languages; }\end{array}$ \\
\hline \#5 & $\begin{array}{l}\# 4 \mathrm{OR} \# 3 \mathrm{OR} \# 2 \mathrm{OR} \# 1 \\
\text { DocType=All document types; Language=All languages; }\end{array}$ \\
\hline$\# 4$ & 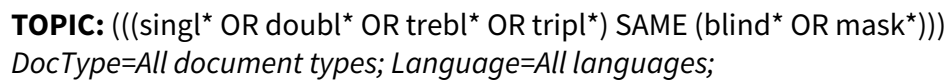 \\
\hline$\# 3$ & $\begin{array}{l}\text { TOPIC: }\left(\left(\text { clin }^{\star} \text { SAME trial }{ }^{\star}\right)\right) \\
\text { DocType=All document types; Language=All languages; }\end{array}$ \\
\hline$\# 2$ & $\begin{array}{l}\text { TOPIC: }((\text { placebo*)) } \\
\text { DocType=All document types; Language=All languages; }\end{array}$ \\
\hline$\# 1$ & $\begin{array}{l}\text { TOPIC: }\left(\left(\text { random }^{\star}\right)\right) \\
\text { DocType=All document types; Language=All languages; }\end{array}$ \\
\hline
\end{tabular}

\section{FEE D B A C K}

\section{Reply to the comments made by Dr Brian Buckley, 9 June 2017}

\section{Summary}

In response to feedback from Dr Brian Buckley we have made some minor amendments to the review regarding the included study Buckley 2014. These amendments are detailed below. This did not lead to any changes in the conclusions of the review.

The feedback received from Dr Brian Buckley on 1 May 2017 is given below:

1.

The Beeckman 2016 review (says that the Philippines trial, Buckley 2014, did not report assessment procedures or on blinding (pages 14-15). Risk of bias is therefore judged in the review as high for blinding of outcome assessment (page 16 and characteristics of studies table, which states that blinding was not possible).

In fact, the Philippines trial report (Buckley 2014) describes assessment procedures and blinding in detail:

Randomisation and blinding 
Blinding of participants and study clinical staff was not possible because the investigational products differ in appearance and odour. However, assessment of the primary IAD severity score outcome was conducted by independent Wound, Ostomy and Continence Nursing Certification Board (WOCNCB)-certified wound care expert assessors who were blinded to treatment allocation.

At each data collection, high-definition photographs were taken using standard operating procedures to facilitate subsequent blind assessment of the primary outcome. Photographs included a measuring guide and were taken at least three times, both with flash and without. ... Residual ointment was meticulously removed using mineral oil so that photographs would not provide blinded assessors with information about which ointment was used.

For determination of final trial results for the primary outcome, sets of photographs for each patient on each treatment day were assessed by WOCNCB-certified wound care specialists in the United States (US) who were blinded to treatment allocation, independent of both the sponsors and the investigating team and were not involved in any other aspect of the study....

2.

In the Beeckman 2016 review data are reported regarding residual IAD at the end of trial participation for one trial, but not the Philippines trial (page 19) (Buckley 2014). In the Philippines trial (Buckley 2014), all participants entered the Philippines trial WITH IAD, and the primary outcome of the trial was healing; therefore all participants NOT healed by definition still had IAD.

3.

In the Beeckman 2016 review it is stated that adverse events were not reported (page 20). In the Philippines trial (Buckley 2014) report it is stated that "No adverse medical events occurred during the study."

4.

In the Beeckman 2016 review it is stated that numbers of people with bacterial or fungal infection were not reported by included trials (page 20). However, the occurrence of fungal infection in four participants is reported for the Philippines trial in the review's characteristics of studies table, as it was in the trial report (Buckley 2014).

\section{Reply}

We made the following changes for Comparison 1: Any topical skin care product versus another topical skin care product. These changes have had no consequences for the conclusions of our review.

- Blinding of outcome assessment

We made corrections to Effects of interventions, Discussion, Figure 2; Figure 3, and Characteristics of included studies describing the low risk of bias in the Buckley 2014 trial.

- Outcome 'Number of participants with IAD residual (i.e. not healed)

We calculated this outcome based on the frequencies reported in the Buckley 2014 trial. The results were added to Effects of interventions, Summary of findings for the main comparison, and Discussion,

- Outcome 'Adverse effects (of the interventions)

We added to Effects of interventions that the Buckley 2014 trial didn't determine any adverse effects while using Desitin and Calmoseptine.

- Outcome 'Number of participants with bacterial or fungal infection'

We added to Effects of interventions that in the Buckley 2014 trial four participants were withdrawn because of fungal infections in the IAD area.

We performed a rigorous check of the review data. Most papers were difficult to analyse because of unclear descriptions of methods, analyses, and results, We made many efforts to perform these analyses to the best of our capabilities. Based on the latest checks, we altered the following small elements without any consequences for the conclusions of the review:

Abstract and plain language summary:

We recalculated and corrected the total sample size (1316 versus 1295).

Comparison 1: Any topical skin care product versus another topical skin care product:

- Outcome 'Number of participants with IAD new': 
In Effects of interventions for the Anthony 1987 trial, we switched Sudocrem and standard zinc oxide. In Analysis 1.6, sample sizes were corrected.

- Outcome 'Number of participants with IAD completely healed':

In Effects of interventions for the Buckley 2014 trial, the results were changed for the results from the intention to treat analysis . In Analysis 1.5 the labels were reversed.

- Outcome 'IAD severity':

In Effects of interventions for the Lewis-Byers 2002 trial, we switched the sample sizes of the two groups.

Comparison 2: Any skin care procedure (method or frequency of application) versus any unstructured skin care procedure:

- Outcome 'Adverse effects (of the interventions)

In Effects of interventions for the Schoonhoven 2015 trial, we added the finding 'No Suspected Unexpected Serious Adverse Reactions occurred'.

Tables Characteristics of included studies

- Anthony 1987: results from reduction in erythema at day 7 and at day 14 were switched between groups.

- Baatenburg de Jong 2004: mean age and BMI were switched between groups; Improvement in skin damage score in favour of group B instead of group A; Reduction in redness, denudation: 'A' was changed by be 'B'.

- Conley 2014: Braden score 16 was changed to 15.

- Lewis-Byers 2002: in participant characteristics: group A and B were switched.

\section{Contributors}

Dr Brian Buckley, trialist on an included study (Buckley 2014) contributed feedback on this review (Beeckman 2016).

Dimitri Beeckman and Nele Van Damme, two of the authors of this review, provided the response.

\section{WHAT'S NEW}

\begin{tabular}{lll}
\hline Date & Event & Description \\
\hline 7 August 2017 & Feedback has been incorporated & $\begin{array}{l}\text { In response to Feedback from Mr Brian Buckley, one of the au- } \\
\text { thors of the included study Buckley 2014 minor amendments } \\
\text { have been made to this review. They are detailed under the } \\
\text { 'Feedback' heading in the review. These minor amendments } \\
\text { have not led to any changes in the conclusions of the review. }\end{array}$ \\
\end{tabular}

\section{CONTRIBUTIONS OF AUTHORS}

- Draft the protocol: all review authors.

- Develop the search strategy: Dimitri Beeckman and Aurélie Van Lancker with assistance from the Cochrane Incontinence Group Information Specialist.

- Develop the data extraction form: Dimitri Beeckman and Aurélie Van Lancker.

- Search for records: Nele Van Damme, Karen Van den Bussche, and Aurélie Van Lancker.

- Obtain copies of records: Sue Woodward and Jan Kottner.

- Selection of records: Nele Van Damme, Karen Van den Bussche, and Aurélie Van Lancker.

- Data extraction: Sue Woodward and Jan Kottner.

- Assessment of risk of bias: Mikel Gray, Lisette Schoonhoven, Jan Kottner, Sue Woodward, Dorien De Meyer, and Dimitri Beeckman.

- Enter data in RevMan and GRADEpro: Nele Van Damme, Karen Van den Bussche, and Aurélie Van Lancker.

- Carry-out the analysis: Dimitri Beeckman, Aurélie Van Lancker, and Dorien De Meyer.

- Interpret the analysis: all review authors.

- Draft the final review: all review authors.

- Update the review: all review authors.

Interventions for preventing and treating incontinence-associated dermatitis in adults (Review) 


\section{DECLARATIONS OF INTEREST}

- Dimitri Beeckman: none known.

- Nele Van Damme: none known.

- Lisette Schoonhoven: none known.

- Aurélie Van Lancker: none known.

- Jan Kottner: none known.

- Hilde Beele: none known.

- Mikel Gray: none known.

- Sue Woodward: none known.

- Mandy Fader: none known.

- Karen Van den Bussche: none known.

- Ann Van Hecke: none known.

- Dorien De Meyer: none known.

- Sofie Verhaeghe: none known.

\section{SOURCES OF SUPPORT}

\section{Internal sources}

- No sources of support supplied

\section{External sources}

- National Institute for Health Research, UK.

This project was supported by the National Institute for Health Research (NIHR), via Cochrane Infrastructure, Cochrane Programme Grant or Cochrane Incentive funding to the Incontinence Group. The views and opinions expressed therein are those of the authors and do not necessarily reflect those of the Systematic Reviews Programme, NIHR, National Health Service (NHS) or the Department of Health.

\section{DIFFERENCES BETWEEN PROTOCOLANDREVIEW}

The original protocol stated that Embase would be searched as a separate database. However, as Cochrane now performs centralised searches of Embase and uploads the results into CENTRAL, the search of CENTRAL was considered adequate to retrieve relevant Embase records without the need to run a separate Embase search.

It was not possible to perform a funnel plot to assess reporting bias because of non-comparable designs and outcomes.

Three additional outcomes were judged to be important for patients during the course of the review process. These outcomes were: IAD severity, number of participants with IAD completely healed, and number of participants with bacterial or fungal infection.

\section{N DEX TERMS}

\section{Medical Subject Headings (MeSH)}

Administration, Topical; Amitriptyline [administration \& dosage]; Dermatitis [etiology] [prevention \& control] [*therapy]; Dermatologic Agents [ ${ }^{*}$ administration \& dosage]; Fecal Incontinence [ ${ }^{*}$ complications]; Petrolatum [administration \& dosage]; Randomized Controlled Trials as Topic; Skin Care [methods]; Skin Cream [administration \& dosage]; Soaps [administration \& dosage]; Urinary Incontinence [ ${ }^{\star}$ complications]; Zinc Oxide [administration \& dosage]

\section{MeSH check words}

Adult; Humans 